\title{
Abortion Surveillance — United States, 2015
}

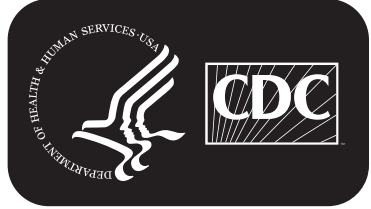




\section{CONTENTS}

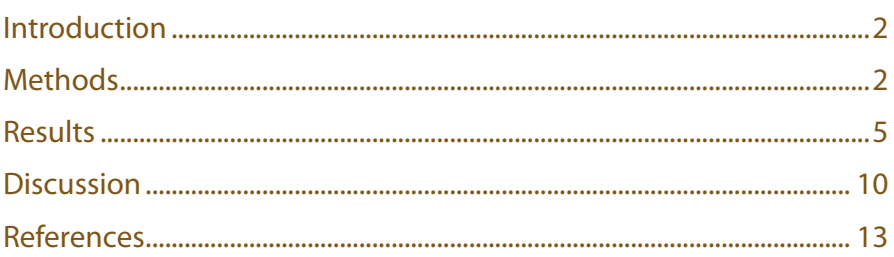

The MMWR series of publications is published by the Center for Surveillance, Epidemiology, and Laboratory Services, Centers for Disease Control and Prevention (CDC), U.S. Department of Health and Human Services, Atlanta, GA 30329-4027.

Suggested citation: [Author names; first three, then et al., if more than six.] [Title]. MMWR Surveill Summ 2018;67(No. SS-\#):[inclusive page numbers].

\section{Centers for Disease Control and Prevention} Robert R. Redfield, MD, Director

Anne Schuchat, MD, Principal Deputy Director

Leslie Dauphin, PhD, Acting Associate Director for Science

Barbara Ellis, PhD, MS, Acting Director, Office of Science Quality

Chesley L. Richards, MD, MPH, Deputy Director for Public Health Scientific Services

William R. Mac Kenzie, MD, Acting Director, Center for Surveillance, Epidemiology, and Laboratory Services

MMWR Editorial and Production Staff (Serials)

Charlotte K. Kent, PhD, MPH, Acting Editor in Chief, Executive Editor Christine G. Casey, MD, Editor

Mary Dott, MD, MPH, Online Editor

Teresa F. Rutledge, Managing Editor

David C. Johnson, Lead Technical Writer-Editor

Kristy Gerdes, MPH, Project Editor

Matthew L. Boulton, MD, MPH

Virginia A. Caine, MD

Katherine Lyon Daniel, PhD

Jonathan E. Fielding, MD, MPH, MBA

David W. Fleming, MD

William E. Halperin, MD, DrPH, MPH
MMWR Editorial Board

Timothy F. Jones, MD, Chairman

Robin Ikeda, MD, MPH

Phyllis Meadows, PhD, MSN, RN

Jewel Mullen, MD, MPH, MPA

Jeff Niederdeppe, $\mathrm{PhD}$

Patricia Quinlisk, MD, MPH
Martha F. Boyd, Lead Visual Information Specialist Maureen A. Leahy, Julia C. Martinroe, Stephen R. Spriggs, Tong Yang, Visual Information Specialists

Quang M. Doan, MBA, Phyllis H. King, Terraye M. Starr, Moua Yang, Information Technology Specialists

Stephen C. Redd, MD,

Patrick L. Remington, MD, MPH

Carlos Roig, MS, MA

William Schaffner, MD

Morgan Bobb Swanson, BS 


\title{
Abortion Surveillance — United States, 2015
}

\author{
Tara C. Jatlaoui, $\mathrm{MD}^{1}$ \\ Maegan E. Boutot, MS $S^{1,2}$ \\ Michele G. Mandel ${ }^{1}$ \\ Maura K. Whiteman, $\mathrm{PhD}^{1}$ \\ Angeline Ti, MD ${ }^{1}$ \\ Emily Petersen, $\mathrm{MD}^{1}$ \\ Karen Pazol, $\mathrm{PhD}^{1}$ \\ ${ }^{1}$ Division of Reproductive Health, National Center for Chronic Disease Prevention and Health Promotion, CDC \\ ${ }^{2}$ Oak Ridge Institute for Science and Education (ORISE) Fellow
}

\begin{abstract}
Problem/Condition: Since 1969, CDC has conducted abortion surveillance to document the number and characteristics of women obtaining legal induced abortions in the United States.
\end{abstract}

Period Covered: 2015.

Description of System: Each year, CDC requests abortion data from the central health agencies of 52 reporting areas (the 50 states, the District of Columbia, and New York City). The reporting areas provide this information voluntarily. For 2015, data were received from 49 reporting areas. Abortion data provided by these 49 reporting areas for each year during 2006-2015 were used in trend analyses. Census and natality data were used to calculate abortion rates (number of abortions per 1,000 women aged 15-44 years) and ratios (number of abortions per 1,000 live births), respectively.

Results: A total of 638,169 abortions for 2015 were reported to CDC from 49 reporting areas. Among these 49 reporting areas, the abortion rate for 2015 was 11.8 abortions per 1,000 women aged 15-44 years, and the abortion ratio was 188 abortions per 1,000 live births. From 2014 to 2015, the total number of reported abortions decreased 2\% (from 652,639), the abortion rate decreased 2\% (from 12.1 abortions per 1,000 women aged 15-44 years), and the abortion ratio decreased 2\% (from 192 abortions per 1,000 live births). From 2006 to 2015, the total number of reported abortions decreased 24\% (from 842,855), the abortion rate decreased 26\% (from 15.9 abortions per 1,000 women aged 15-44 years), and the abortion ratio decreased 19\% (from 233 abortions per 1,000 live births). In 2015, all three measures reached their lowest level for the entire period of analysis (2006-2015). In 2015 and throughout the period of analysis, women in their 20s accounted for the majority of abortions and had the highest abortion rates; women aged $\geq 30$ years accounted for a smaller percentage of abortions and had lower abortion rates. In 2015, women aged 20-24 and 25-29 years accounted for 31.1\% and 27.6\% of all reported abortions, respectively, and had abortion rates of 19.9 and 17.9 abortions per 1,000 women aged 20-24 and 25-29 years, respectively. In contrast, women aged 30-34, $35-39$, and $\geq 40$ years accounted for $17.7 \%, 10.0 \%$, and $3.5 \%$ of all reported abortions, respectively, and had abortion rates of 11.6, 7.0, and 2.5 abortions per 1,000 women aged 30-34, 35-39, and $\geq 40$ years, respectively. From 2006 to 2015, the abortion rate decreased among women in all age groups.

In 2015, adolescents aged $<15$ and $15-19$ years accounted for $0.3 \%$ and $9.8 \%$ of all reported abortions, respectively, and had abortion rates of 0.5 and 6.7 abortions per 1,000 adolescents aged $<15$ and $15-19$ years, respectively. From 2006 to 2015 , the percentage of abortions accounted for by adolescents aged 15-19 years decreased 41\%, and their abortion rate decreased 54\%. This decrease in abortion rate was greater than the decreases for women in any older age group.

In contrast to the percentage distribution of abortions and abortion rates by age, abortion ratios in 2015 and throughout the entire period of analysis were highest among adolescents and lowest among women aged 25-39 years. Abortion ratios decreased from 2006 to 2015 for women in all age groups.

In 2015, almost two thirds (65.4\%) of abortions were performed at $\leq 8$ weeks' gestation, and nearly all (91.1\%) were performed at $\leq 13$ weeks' gestation. Few abortions were performed between 14 and 20 weeks' gestation $(7.6 \%)$ or at $\geq 21$ weeks' gestation (1.3\%).

Corresponding author: Division of Reproductive Health, National Center for Chronic Disease Prevention and Health Promotion, CDC. E-mail: cdcinfo@cdc.gov. During 2006-2015 the percentage of all abortions performed at $>13$ weeks' gestation remained consistently low $(\leq 9.0 \%)$. Among abortions performed at $\leq 13$ weeks' gestation, a shift occurred toward earlier gestational ages, with the percentage performed at $\leq 6$ weeks' gestation increasing $11 \%$. 
In $2015,24.6 \%$ of all abortions were performed by early medical abortion (a nonsurgical abortion at $\leq 8$ weeks' gestation), $64.3 \%$ were performed by surgical abortion at $\leq 13$ weeks' gestation, and $8.8 \%$ were performed by surgical abortion at $>13$ weeks' gestation; all other methods were uncommon $(\leq 2.2 \%)$. Among those that were eligible for early medical abortion on the basis of gestational age (i.e., performed at $\leq 8$ weeks' gestation), $35.8 \%$ were completed by this method.

In 2015, women with one or more previous live births accounted for $59.3 \%$ of abortions, and women with no previous live births accounted for $40.7 \%$. Women with one or more previous induced abortions accounted for $43.6 \%$ of abortions, and women with no previous abortion accounted for $56.3 \%$. Women with three or more previous births accounted for $14.2 \%$ of abortions, and women with three or more previous abortions accounted for $8.2 \%$ of abortions.

Deaths of women associated with complications from abortion for 2015 are being assessed as part of CDC's Pregnancy Mortality Surveillance System. In 2014, the most recent year for which data were available, six women were identified to have died as a result of complications from legal induced abortion.

Interpretation: Among the 49 areas that reported data every year during 2006-2015, decreases in the total number, rate, and ratio of reported abortions resulted in historic lows for the period of analysis for all three measures of abortion.

Public Health Action: The data in this report can help program planners and policymakers identify groups of women with the highest rates of abortion. Unintended pregnancy is the major contributor to induced abortion. Increasing access to and use of effective contraception can reduce unintended pregnancies and further reduce the number of abortions performed in the United States.

\section{Introduction}

This report summarizes abortion data for 2015 that were provided voluntarily to CDC by the central health agencies of 49 reporting areas (the District of Columbia [DC]; New York City; and 47 states, [excluding California, Maryland, and New Hampshire]). Data obtained every year during 2006-2015 from these same 49 reporting areas were used for trend analyses.

Since 1969, CDC has conducted abortion surveillance to document the number and characteristics of women obtaining legal induced abortions in the United States (1). After nationwide legalization of abortion in 1973, the total number, rate (number of abortions per 1,000 women aged 15-44 years), and ratio (number of abortions per 1,000 live births) of reported abortions increased rapidly, reaching the highest levels in the 1980s before decreasing at a slow yet steady pace (2-4). During 2006-2008, a break occurred in the previously sustained pattern of decrease (5-8), although this break has been followed in all subsequent years by even greater decreases (9-16). Nonetheless, throughout the years, the incidence of abortion has varied considerably across subpopulations and remains higher in certain demographic groups than others (17-22). Continued surveillance is needed to monitor changes in the incidence of abortion in the United States.

\section{Methods}

\section{Description of the Surveillance System}

Each year, CDC requests aggregated data from the central health agencies of 52 reporting areas (the 50 states, DC, and
New York City) to document the number and characteristics of women obtaining legal induced abortions in the United States. This report contains data reported to CDC as of April 1, 2018. For the purpose of surveillance, a legal induced abortion* is defined as an intervention performed within the limits of state law by a licensed clinician (e.g., a physician, nurse-midwife, nurse practitioner, or physician assistant) that is intended to terminate a suspected or known intrauterine pregnancy.

In most states, collection of abortion data are facilitated by the legal requirement for hospitals, facilities, and physicians to report all abortions to a central health agency (23). These central health agencies then voluntarily report the abortion data they have collected through their independent surveillance systems (24). However, although reporting to CDC is voluntary, most reporting areas provide their abortion numbers.

Although CDC obtains abortion numbers from most of the central health agencies, it receives only aggregate numbers and reporting is not complete in all areas, including in certain areas with reporting requirements (24). Moreover, the level of detail received on the characteristics of women obtaining abortions varies considerably from year to year and by reporting area (15). To encourage more uniform collection of these details, CDC has collaborated with the National Association for Public Health Statistics and Information Systems to develop reporting standards and provide technical guidance for vital statistics personnel who collect and summarize abortion data within the United States. However, because the collection and reporting of abortion data are not federally mandated, many

\footnotetext{
${ }^{*}$ Hereafter, all abortions in this report are considered to be legally induced unless stated to be illegally induced.
} 
reporting areas have developed their own data collection forms, and therefore do not collect or provide all the information or level of detail included in this report.

\section{Variables and Categorization of Data}

Each year, CDC sends suggested templates to the central health agencies for compilation of abortion data in aggregate. Aggregate abortion numbers, without individual-level records, are requested for the following variables:

- Maternal age in years $(<15,15-19$ by individual year, 20-24, 25-29, 30-34, 35-39, or $\geq 40$ )

- Gestational age in completed weeks at the time of abortion $(\leq 6,7-20$ by individual week, or $\geq 21)$

- Race (black, white, or other [including Asian, Pacific Islander, other races, and multiple races]), ethnicity (Hispanic or non-Hispanic), and race by ethnicity

- Method type (surgical abortion, ${ }^{\dagger}$ intrauterine instillation, medical [nonsurgical] abortion, or hysterectomy/hysterotomy)

- Marital status (married [including currently married or separated] or unmarried [including never married, widowed, or divorced])

- Number of previous live births $(0,1,2,3$, or $\geq 4)$

- Number of previous abortions (0, 1, 2, or $\geq 3)$

- Maternal residence (the state, reporting area, territory, or foreign country in which the woman obtaining the abortion lived; or, if additional details are unavailable, in-reporting area versus out-of-reporting area)

In addition, templates provided by CDC request that aggregate numbers for certain variables be cross-tabulated by a second variable. These cross-tabulations include gestational age (separately by maternal age, by method type, by race, by ethnicity, and by race/ethnicity) and maternal age and marital status (separately by race, by ethnicity, and by race/ethnicity).

Beginning with 2014 data, instead of reporting clinician's estimates of gestational age or estimates of gestational age on the basis of last menstrual period, certain areas reported "probable postfertilization age" and "clinician's estimate of gestation based on date of conception" to CDC. To make data reported as postfertilization age consistent with gestational age data collection practices recommended by the CDC's National Center for Health Statistics (25), 2 weeks were added to probable postfertilization age. This method was used to account for time after last menstrual period until ovulation in a standard 28-day cycle, because fertilization occurs around the time of ovulation (26). No modifications were made to data reported as clinician's estimate of gestation based on date of conception.

\footnotetext{
$\dagger^{\dagger}$ Includes aspiration curettage, suction curettage, manual vacuum aspiration, menstrual extraction, sharp curettage, and dilation and evacuation procedures.
}

In this report, medical and surgical abortions are further categorized by gestational age. Early medical abortion is defined as the administration of medication or medications (typically mifepristone followed by misoprostol) to induce an abortion at $\leq 8$ completed weeks' gestation ${ }^{\S}$; medical abortion at $>8$ completed weeks' gestation is defined as the administration of medication or medications (typically serial vaginal prostaglandins, sometimes after mifepristone) to induce an abortion at $>8$ weeks' gestation. For surgical abortions, abortions are categorized as having been performed at $\leq 13$ weeks' gestation or at $>13$ weeks' gestation because of differences in technique used generally before and after 13 weeks (28). Finally, because intrauterine instillations cannot be performed early in gestation, abortions reported to have been performed by intrauterine instillation at $\leq 12$ weeks' gestation are excluded from calculation of the percentage of abortions by known method type.

\section{Measures of Abortion}

Four measures of abortion are presented in this report: 1) the number of abortions in a given population, 2) the percentage of abortions obtained by women in a given population, 3 ) the abortion rate (number of abortions per 1,000 women aged 15-44 years or other specific group within a given population), and 4) the abortion ratio (number of abortions per 1,000 live births within a given population). Although total numbers and percentages are useful for determining how many women have obtained an abortion, abortion rates adjust for differences in population size and reflect how likely abortion is among women in particular groups. Abortion ratios measure the relative number of pregnancies in a population that end in abortion compared with live birth. Abortion ratios are influenced both by the proportion of pregnancies in a population that are unintended and the proportion of unintended pregnancies that end in abortion. Abortion ratios also are influenced by the proportion of intended pregnancies that end in abortion; however, intended pregnancies account for a very limited percentage of abortions $(<5 \%)(31)$.

U.S. Census Bureau estimates of the resident female population of the United States were used as the denominator

\footnotetext{
$\$$ CDC collects information only on the estimated number of weeks (not days) of gestation and acknowledges the conventional use of completed weeks of gestation to describe pregnancy duration. CDC's category $\leq 8$ weeks' gestation thus includes abortions up through 8 weeks and 6 days. This closely corresponds to the performance measure for medical abortion proposed by the American College of Obstetricians and Gynecologists (27).

The cutoff of $\leq 12$ weeks was selected on the basis of the implausibility of this procedure being performed at earlier gestational ages and on the basis of early research assessing the safety of intrauterine instillations starting at 13 weeks gestation $(29,30)$.
} 
for calculating abortion rates (32-41). Overall abortion rates were calculated from the population of women aged 15-44 years living in the reporting areas that provided data. For adolescents aged $<15$ years, abortion rates were determined on the basis of the number of adolescents aged 13-14 years; similarly, for women aged $\geq 40$ years, abortion rates were determined on the basis of the number of women aged $40-44$ years. For the calculation of abortion ratios, live birth data were obtained from CDC natality files and included births to women of all ages living in the reporting areas that provided abortion data (42).

\section{Data Presentation and Analysis}

This report provides state-specific and overall abortion numbers, rates, and ratios for the 49 areas that reported to CDC for 2015 (excludes California, Maryland, and New Hampshire). In addition, this report describes the characteristics of women who obtained abortions in 2015. Because the completeness of reporting on the characteristics of women varies by year and by variable, this report only describes the characteristics of women obtaining abortions in areas that met reporting standards (i.e., reported at least 20 abortions overall, provided data categorized in accordance with surveillance variables, and had $<15 \%$ unknown values for a given characteristic). Abortion rates and ratios have been omitted for reporting areas with $<20$ abortions because results are considered unstable (43). Cells with a value in the range of $1-4$ or cells that would allow for calculation of these values have been suppressed to maintain confidentiality.

Although most of the data are presented by the reporting area in which the abortions were performed, 48 reporting areas in 2015 also provided the number of abortions by maternal residence. ${ }^{* *}$ However, one area only reported abortions for its own residents (DC). Two other areas (Illinois and Wisconsin) reported abortions for in-state and out-of-state residents but did not report certain characteristics for out-of-state residents. Three other reporting areas (Iowa, Massachusetts, and New Mexico) provided only the total number of abortions for outof-state residents without specifying individual states or areas of residence from which these women came. As a result, abortion statistics in this report by area of residence should be interpreted with caution and might underestimate the incidence of abortion, especially for reporting areas from which multiple women travel to other states to obtain abortion services.

To evaluate overall trends in the number, rate, and ratio of reported abortions, annual data are presented for the 49 areas

\footnotetext{
** Excludes three reporting areas that did not report (California, Maryland, and New Hampshire), and one (Florida) that did not report by maternal residence.
}

that reported every year during 2006-2015. Linear regression analysis was used to assess the overall rate of change among these areas during the entire 10-year period of analysis (20062015) and during the first and second halves of the period of analysis (2006-2010 and 2011-2015). The percentage change in abortion measures from the most recent past year (2014 to 2015) and from the beginning to the end of the 10-year period of analysis (2006 to 2015) also were calculated for these same 49 areas. Consistent with previous reports, key findings are highlighted to provide observed changes over time and differences between groups. However, comparisons do not infer statistical significance, and lack of comment regarding the difference between values does not imply that no statistically significant difference exists.

For the analysis of certain additional variables (i.e., abortions by maternal age and gestational age), annual data are presented for areas that met reporting standards every year during 20062015; the percentage change was calculated from the beginning to the end of the 10-year period of analysis (2006 to 2015), from the beginning to the end of the first and second halves of this period (2006 to 2010 and 2011 to 2015), and from the most recent past year (2014 to 2015). For other variables (i.e., race/ethnicity, method type, marital status, number of previous abortions, and number of previous live births), annual data are not presented; areas were included if they met reporting standards for the years needed for percentage change calculations. To evaluate trends in the use of different methods for performing an abortion, reporting areas were included only if they met reporting standards and if they specifically included medical abortion as a method on their reporting form. Trend analyses for race/ethnicity are limited to a 9-year span (2007-2015) because few reporting areas reported data on race by ethnicity (race/ethnicity) before 2007. Medical abortions performed at 9 completed weeks are also reported for 2011 to 2015. These data are reported to monitor any changes in clinical practice that might have occurred with the accumulation of evidence on the safety and effectiveness of medical abortion past 63 days of gestation ( $\leq 8$ completed weeks) (44) and changes in professional practice guidelines published in 2013 and 2014 $(45,46)$. Both of these events preceded the 2016 U.S. Food and Drug Administration (FDA) extension of the gestational age limit for the use of mifepristone for early medical abortion to 70 days ( $\leq 9$ completed weeks) (47).

Some of the 49 areas that reported for 2015 are not included in certain trend analyses when data did not meet reporting standards. As a result, summary measures for comparisons over time might differ from the point estimates presented for all areas that reported for 2015 . 


\section{Abortion Mortality}

CDC has reported data on abortion-related deaths periodically since information on abortion mortality first was included in the 1972 abortion surveillance report $(15,48)$. An abortion-related death is defined as a death resulting from a direct complication of an abortion (legal or illegal), an indirect complication caused by a chain of events initiated by an abortion, or an aggravation of a preexisting condition by the physiologic or psychologic effects of abortion (49). All deaths determined to be related causally to induced abortion are classified as abortion related regardless of the time between the abortion and death. In addition, any pregnancy-related death in which the pregnancy outcome was induced abortion regardless of the causal relation between the abortion and the death is considered an abortion-related death. An abortion is defined as legal only if it is performed by a licensed clinician within the limits of state law.

Since 1987, CDC has monitored abortion-related deaths through its Pregnancy Mortality Surveillance System (50,51). Sources of data for abortion-related deaths have included state vital records; media reports, including computerized searches of full-text newspaper and other print media databases; and individual case reports by public health agencies, including maternal mortality review committees, health care providers and provider organizations, private citizens, and citizen groups. For each death that possibly is related to abortion, CDC requests clinical records and autopsy reports. Two medical epidemiologists independently review these reports to determine the cause of death and whether the death was abortion related. Discrepancies are discussed and resolved by consensus. Each death is categorized by abortion type as legal induced, illegal induced, spontaneous, or unknown type.

This report provides data from the Pregnancy Mortality Surveillance System on induced abortion-related deaths that occurred in 2014, the most recent year for which data are available. Data on induced abortion-related deaths that occurred during 1972-2013 already have been published (15), and possible abortion-related deaths that occurred during 2015-2018 are being assessed. During 1998-2014, abortion surveillance data reported to CDC cannot be used alone to calculate national case-fatality rates (number of legal induced abortion-related deaths per 100,000 reported legal induced abortions in the United States) because certain states ${ }^{\dagger \dagger}$ did not report abortion data every year during this period. Thus, national legal induced abortion case-fatality rates were

\footnotetext{
†† States that did not report for $\geq 1$ year since 1998 include Alaska (1998-2000), California (1998-2015), Louisiana (2005), Maryland (2007-2013), New Hampshire (1998-2013), Oklahoma (1998-1999), and West Virginia (2003-2004).
}

calculated with denominator data from a provider census for the total number of abortions performed in the United States (16). Because rates determined on the basis of a numerator of $<20$ deaths are highly variable (43), national legal induced abortion case-fatality rates were calculated for consecutive 5-year periods during 1973-2007 and for a consecutive 7-year period during 2008-2014.

\section{Results}

\section{U.S. Totals}

Among the 49 reporting areas that provided data for 2015, a total of 638,169 abortions were reported. All 49 of these areas provided data every year during $2006-2015 . \$ \$ \$$ In 2015 , these areas had an abortion rate of 11.8 abortions per 1,000 women aged 15-44 years and an abortion ratio of 188 abortions per 1,000 live births (Table 1). From 2014 to 2015, the total number of reported abortions decreased 2\% (from 652,639 to 638,169 ), the abortion rate decreased $2 \%$ (from 12.1 to 11.8 abortions per 1,000 women aged $15-44$ years), and the abortion ratio decreased $2 \%$ (from 192 to 188 abortions per 1,000 live births). From 2006 to 2015, the total number of reported abortions decreased $24 \%$ (from 842,855), the abortion rate decreased 26\% (from 15.9 abortions per 1,000 women aged 15-44 years), and the abortion ratio decreased 19\% (from 233 abortions per 1,000 live births) (Figure 1). Among these same 49 areas, the annual rate of decrease fitted from the regression analysis was greater during 2011-2015 than during 2006-2010 for all three measures of abortion. During 2011-2015, the number of reported abortions decreased by 23,087 abortions per year, the abortion rate decreased by 0.48 abortions per 1,000 women per year, and the abortion ratio decreased by 7.4 abortions per 1,000 live births per year. In contrast, during 2006-2010, the number of reported abortions decreased by 19,280 abortions per year, the abortion rate decreased by 0.37 abortions per 1,000 women per year, and the abortion ratio decreased by 1.7 abortions per 1,000 live births per year.

\section{Occurrence and Residence}

Abortion numbers, rates, and ratios for 2015 have been calculated by reporting area of occurrence and the residence of the women who obtained the abortions (Table 2). By reporting area of occurrence, a considerable range existed in the abortion rate (from 2.8 abortions per 1,000 women aged 15-44 years in South Dakota to 23.1 abortions per 1,000 women in New

\footnotetext{
$\$ \$$ Excludes California, Maryland, and New Hampshire.
} 
York [city and state combined]) and the abortion ratio (from 36 abortions per 1,000 live births in South Dakota to 392 abortions per 1,000 live births in New York [city and state combined]). IS Similarly, a considerable range existed by residence*** in the abortion rate (from 4.2 abortions per 1,000 women aged 15-44 years in South Dakota to 22.0 abortions per 1,000 women aged 15-44 years in New York [city and state combined]) and the abortion ratio (from 53 abortions per 1,000 live births in South Dakota to 374 abortions per 1,000 live births in New York [city and state combined]). Because of variation that occurred among reporting areas in the percentage of abortions obtained by out-of-state residents (from $0.3 \%$ in Hawaii to $49.0 \%$ in Kansas), ${ }^{\dagger \dagger \dagger}$ abortion rates and ratios calculated by maternal residence might provide a more accurate reflection of the state-specific distribution of women obtaining abortions. However, because states vary in the level of detail they collect on maternal residence, $12.7 \%$ of abortions were reported to CDC with unknown information on maternal residence.

\section{Maternal Age}

Among the 47 areas that reported by maternal age for 2015 , women in their 20 s accounted for the majority (58.7\%) of abortions and had the highest abortion rates (19.9 and 17.9 abortions per 1,000 women aged 20-24 and 25-29 years, respectively) (Figure 2 ) (Table 3 ). Women in the youngest $(<15$ years) and oldest ( $\geq 40$ years) age groups accounted for the smallest percentages of abortions ( $0.3 \%$ and $3.5 \%$, respectively) and had the lowest abortion rates $(0.5$ and 2.5 abortions per 1,000 women aged $<15$ and $\geq 40$ years, respectively). Among the 44 reporting areas that provided data by maternal age every year during 2006-2015, this pattern across age groups was stable, with the majority of abortions and the highest abortion rates occurring among women aged 20-29 years and the lowest percentages of abortions and abortion rates occurring among women in the youngest and oldest age groups (Table 4). From 2006 to 2015, abortion rates decreased among all age groups, although the decreases for adolescents (58\% and 54\% for adolescents aged $<15$ and 15-19 years, respectively) were greater than the decreases for women in all older age groups, with decreases for women aged $\geq 20$ years ranging from $4 \%$

\footnotetext{
Is Comparisons do not include Wyoming, which reported $<20$ abortions.

*** Comparisons by residence status do not include California, Florida, Maryland, or New Hampshire. Because these areas either did not report or did not report abortions by maternal residence, numbers are available only from other reporting areas where their residents obtained abortions, and as a consequence meaningful statistics cannot be reported.

$\dagger \dagger$ Comparisons do not include District of Columbia, which only reported abortions for area residents.
}

among women aged $\geq 40$ years to $33 \%$ among women aged 20-24 years. Decreases in the abortion rate for all age groups, except women aged 25-29 years, were greater from 2011 to 2015 than from 2006 to 2010, and the rates for all age groups either remained the same or decreased from 2014 to 2015.

In contrast to the percentage of abortions and abortion rates, abortion ratios in 2015 were highest among adolescents aged $\leq 19$ years and lowest among women aged $25-39$ years (Figure 2 ) (Table 3). Among the 44 reporting areas that provided data by maternal age for every year during 2006-2015, abortion ratios decreased among women in all age groups. The abortion ratio decreased for all age groups from 2011 to 2015; from 2006 to 2010 , it decreased for women in all age groups, except for those aged $<15$ and 20-24 years. In addition, for every age group with declines for both periods, the declines that occurred from 2011 to 2015 exceeded the declines from 2006 to 2010 . Declines occurred for all age groups from 2014 to 2015 with the exception of women aged 25-29 years (Table 4).

\section{Adolescents}

Among the 45 areas that reported maternal age by individual year among adolescents for 2015, adolescents aged 18-19 years accounted for the majority $(67.8 \%)$ of adolescent abortions and had the highest adolescent abortion rates (9.6 and 13.2 abortions per 1,000 adolescents aged 18 and 19 years, respectively). Adolescents aged $<15$ years accounted for the smallest percentage of adolescent abortions (2.7\%) and had the lowest adolescent abortion rate $(0.5$ abortions per 1,000 adolescents aged 13-14 years) (Table 5). Among the 40 reporting areas that provided maternal age data for adolescents for each individual year of reporting during 2006-2015, the percentage of abortions accounted for by adolescents aged 18-19 years increased, whereas the percentage of abortions accounted for by adolescents aged $<18$ years decreased (Table 6). For adolescents of all ages, large decreases in abortion rates occurred from 2006 to 2015 (48\%-64\%) and were greater from 2011 to 2015 than from 2006 to 2010 . Decreases continued among all adolescents aged $\geq 15$ years from 2014 to 2015.

In 2015, the abortion ratio for adolescents was highest among adolescents aged $<15$ years $(684$ abortions per 1,000 live births among adolescents aged $<15$ years) and was lowest among adolescents aged $\geq 17$ years $(285,292$, and 247 abortions per 1,000 live births among adolescents aged 17, 18, and 19 years, respectively) (Table 5). During 2006-2015 and 2011-2015, abortion ratios decreased among adolescents of all ages (Table 6). 


\section{Gestational Age}

Among the 40 areas that reported gestational age ${ }^{\$ \$ \$}$ at the time of abortion for 2015, approximately two thirds (65.4\%) of abortions were performed by $\leq 8$ weeks' gestation, and nearly all $(91.1 \%)$ were performed at $\leq 13$ weeks' gestation (Table 7 ). Few abortions were performed at 14-20 weeks' gestation $(7.6 \%)$ or at $\geq 21$ weeks' gestation $(1.3 \%)$. Among the 33 reporting areas that provided data on gestational age every year during 2006-2015, the percentage of abortions performed at $\leq 13$ weeks' gestation declined minimally from $91.5 \%$ to $91.0 \%$ (Table 8). However, within this gestational age range, a shift occurred toward earlier gestational ages, with the percentage of abortions performed at $\leq 8$ weeks' gestation increasing 3\% and the percentage of abortions performed at 9-13 weeks' gestation decreasing 9\%. For the entire period of analysis, abortions performed at $>13$ weeks' gestation accounted for $\leq 9.0 \%$ of abortions.

Among abortions performed at $\leq 13$ weeks' gestation and reported by individual week of gestation for 2015, 37.6\% were performed at $\leq 6$ weeks' gestation (Table 9). The percentage contribution to abortions performed at $\leq 13$ weeks' gestation was progressively smaller for each additional week of gestation: $19.6 \%$ were performed at 7 weeks' gestation, and $3.1 \%$ were performed at 13 weeks' gestation. Among the 33 areas that reported by exact week of gestation for abortions performed at $\leq 13$ weeks' gestation every year during 2006-2015, a shift occurred toward the earliest gestational age reported: abortions performed at $\leq 6$ weeks' gestation increased $11 \%$, those performed at 7-12 weeks' gestation decreased 3\%-15\%, and those performed at 13 weeks' gestation were stable (Table 10).

\section{Method Type}

Among the 43 areas that reported by method type for 2015 and included medical abortion on their reporting form, $64.3 \%$ of abortions were surgical abortions at $\leq 13$ weeks' gestation, $24.6 \%$ were early medical abortions (a nonsurgical abortion at $\leq 8$ weeks' gestation), and $8.8 \%$ were surgical abortions at $>13$ weeks' gestation; other methods (medical abortion at $>8$ weeks' gestation, intrauterine instillation, and hysterectomy/ hysterotomy) were uncommon $(\leq 2.2 \%)$ (Table 11$)$. Among the 34 reporting areas $\mathbf{9 9}$ that included medical abortion on their reporting form and provided these data for the relevant

\footnotetext{
\$S\$ Arkansas and Texas reported probable postfertilization age. Two weeks were added to the probable postfertilization age to provide a corresponding measure to gestational age on the basis of the clinician's estimate. Virginia reported clinician's estimate of gestational age based on date of conception; no modifications were made to these data.

999 Excludes Alabama, Arizona, California, Delaware, Florida, Georgia, Hawaii, Illinois, Kentucky, Louisiana, Maryland, Nevada, New Hampshire, New Mexico, Tennessee, Vermont, Wisconsin, and Wyoming.
}

years of comparison (2006 versus 2015, 2006 versus 2010, 2011 versus 2015, and 2014 versus 2015), use of early medical abortion increased $8 \%$ from 2014 to 2015 (from $22.5 \%$ of abortions to $24.2 \%$ ); from 2006 to 2015 , use of early medical abortion increased $114 \%$ (from $11.3 \%$ of abortions to $24.2 \%$ ). Increases in early medical abortion occurred both from 2006 to 2010 (from $11.3 \%$ of abortions to $18.4 \%$ [ $63 \%$ increase]) and from 2011 to 2015 (from 19.2\% of abortions to $24.2 \%$ [26\% increase]).

Among the 30 reporting areas that provided data by procedure and individual week of gestational age each year from 2011 to $2015,{ }^{* * * *}$ when recent clinical guidelines extended mifepristone use to 70 days' gestation, the percentage of abortions at 9 completed weeks' gestation that were reported as medical abortions did not change substantially between 2011, 2012, 2013, and 2014 (5.0\%, 5.7\%, 6.7\%, and 7.7\%, respectively) and then increased to $13.0 \%$ in 2015 . Among the $43^{\dagger+\dagger \dagger}$ areas that reported by method type for 2015 and included medical abortion on their reporting form, $26.0 \%$ were medical abortions performed at $\leq 9$ weeks' gestation. Of these medical abortions performed at $\leq 9$ weeks' gestation, $94.6 \%$ were performed at $\leq 8$ weeks and $5.4 \%$ were performed at 9 weeks.

In contrast to the increase that occurred in use of early medical abortion, use of surgical abortion at $\leq 13$ weeks' gestation decreased 18\% from 2006 to 2015 (from $79.2 \%$ of abortions to $64.7 \%$ ). Surgical abortion at $>13$ weeks' gestation consistently accounted for approximately $8.0 \%-9.0 \%$ of all abortions, and all other methods combined consistently accounted for a limited percentage of abortions (1.4\%-2.4\%) during 2006-2015.

\section{Race/Ethnicity}

Among the 30 areas that reported cross-classified race/ ethnicity data for 2015, non-Hispanic white women and nonHispanic black women accounted for the largest percentages of all abortions (36.9\% and $36.0 \%$, respectively), and Hispanic women and non-Hispanic women in the other race category accounted for smaller percentages $(18.5 \%$ and $8.7 \%$, respectively) (Table 12). Non-Hispanic white women had the lowest abortion rate (6.8 abortions per 1,000 women aged 15-44 years) and ratio (111 abortions per 1,000 live births) and non-Hispanic black women had the highest abortion rate (25.1 abortions per 1,000 women aged $15-44$ years) and ratio (390 abortions per 1,000 live births). Data for 2015 also are reported separately by race and by ethnicity (Tables 13 and 14).

\footnotetext{
**** Excludes Alabama, California, Connecticut, District of Columbia, Florida, Hawaii, Illinois, Kentucky, Louisiana, Maine, Maryland, Massachusetts, Mississippi, Nebraska, New Hampshire, New Mexico, New York State, Pennsylvania, Tennessee, Vermont, Wisconsin, and Wyoming.

††† See Table 11 for list of reporting areas.
} 
Among the 20 areas $\$ \$ \$ \$$ that reported by race/ethnicity for 2007, 2010, 2011, 2014, and 2015, abortion rates decreased substantially for the three largest race/ethnicity groups: for non-Hispanic white women, the abortion rate decreased $30 \%$ (from 9.4 abortions per 1,000 women in 2007 to 6.6 in 2015), for non-Hispanic black women it decreased 29\% (from 36.5 abortions per 1,000 women in 2007 to 25.8 in 2015), and for Hispanic women it decreased $45 \%$ (from 21.0 abortions per 1,000 women in 2007 to 11.6 in 2015). For women in the three largest race/ethnicity groups, abortion rates decreased both from 2007 to 2010 and from 2011 to 2015, although the decreases were greater during the later period. From 2007 to 2010, the abortion rates decreased 10\% for non-Hispanic white women (from 9.4 to 8.5 abortions per 1,000), $4 \%$ for non-Hispanic black women (from 36.5 to 34.9 abortions per 1,000 ), and $10 \%$ for Hispanic women (from 21.0 to 19.0 abortions per 1,000); by contrast, from 2011 to 2015 , the abortion rates decreased $19 \%$ for nonHispanic white women (from 8.1 to 6.6 abortions per 1,000), $20 \%$ for non-Hispanic black women (from 32.3 to 25.8 abortions per 1,000 ), and $31 \%$ for Hispanic women (from 16.9 to 11.6 abortions per 1,000$)$.

Abortion ratios also decreased from 2007 to 2015 for the three largest race/ethnicity groups: for non-Hispanic white women, the abortion ratio decreased 27\% (from 147 abortions per 1,000 live births in 2007 to 108 in 2015), for non-Hispanic black women it decreased 22\% (from 514 abortions per 1,000 live births in 2007 to 403 in 2015), and for Hispanic women it decreased 26\% (from 205 abortions per 1,000 live births in 2007 to 152 in 2015). From 2007 to 2010, abortion ratios only decreased among non-Hispanic white women (6\% from 147 abortion per 1,000 live births in 2007 to 138 in 2010), whereas abortion ratios increased among non-Hispanic black women (3\% from 514 abortions per 1,000 live births in 2007 to 531 in 2010) and Hispanic women (8\% from 205 abortion per 1,000 live births in 2007 to 222 in 2010). By contrast, from 2011 to 2015, abortion ratios decreased among all women in the three largest race/ethnicity groups. The abortion ratio decreased $18 \%$ for non-Hispanic white women (from 132 to 108 abortions per 1,000 live births), 20\% for non-Hispanic black women (from 501 to 403 abortions per 1,000 live births), and $28 \%$ for Hispanic women (from 211 to 152 abortions per 1,000 live births).

\footnotetext{
$\$ \$ \$ \$ \$$ Excludes Alaska, Arizona, California, Connecticut, Delaware, District of Columbia, Florida, Hawaii, Illinois, Iowa, Kentucky, Louisiana, Maine, Maryland, Massachusetts, Michigan, Mississippi, Nebraska, Nevada, New Hampshire, New Mexico, New York State, North Carolina, North Dakota, Oklahoma, Pennsylvania, Rhode Island, South Carolina, Vermont, Washington, Wisconsin, and Wyoming.
}

\section{Marital Status}

Among the 39 areas that reported by marital status for 2015, $14.3 \%$ of all women who obtained an abortion were married, and $85.7 \%$ were unmarried (Table 15 ). The abortion ratio was 41 abortions per 1,000 live births for married women and 373 abortions per 1,000 live births for unmarried women. Among the 30 reporting areas 999 that provided these data for the relevant years of comparison (2006 versus 2015, 2006 versus 2010, 2011 versus 2015, and 2014 versus 2015), the percentage of abortions among unmarried women increased $3 \%$ from 2006 to 2015 (from $83.6 \%$ to $85.9 \%$ ), with a larger increase from 2006 to 2010 (2\%) than from 2011 to 2015 $(<1 \%)$. Among unmarried women, the abortion ratio decreased $21 \%$ from 2006 to 2015 (from 415 to 327 abortions per 1,000 live births), with a larger decrease also occurring from 2011 to 2015 (14\%) than from 2006 to 2010 (6\%). Among married women, the abortion ratio decreased 31\% from 2006 to 2015 (from 49 to 34 abortions per 1,000 live births), with a larger decrease occurring from 2011 to 2015 (19\%) than from 2006 to 2010 (10\%).

\section{Previous Live Births and Abortions}

Data from the 40 areas that reported the number of previous live births for women who obtained abortions in 2015 indicate that $40.7 \%, 45.1 \%$, and $14.2 \%$ of these women had zero, one or two, or three or more previous live births, respectively (Table 16). Among the 35 reporting areas***** that provided these data for the relevant years of comparison (2006 versus 2015, 2006 versus 2010, 2011 versus 2015, and 2014 versus 2015), the percentage of women obtaining abortions with no previous live births was stable; by contrast, the percentage decreased 3\% for women who had one or two previous live births and increased $13 \%$ for women with three or more previous live births. Among the areas included in this comparison, $40.6 \%, 46.6 \%$, and $12.8 \%$ of women had zero, one to two, or three or more previous live births, respectively, in 2006; by comparison $40.6 \%, 45.0 \%$, and $14.4 \%$ of women had zero, one or two, or three or more previous live births, respectively, in 2015.

Data from the 39 areas that reported the number of previous abortions for women who obtained abortions in

\footnotetext{
9999 Excludes Arizona, Arkansas, California, Connecticut, District of Columbia, Florida, Georgia, Louisiana, Maine, Maryland, Massachusetts, Nebraska, Nevada, New Hampshire, New York City, New York State, North Carolina, Ohio, Rhode Island, Vermont, Washington, and Wyoming.

***** Excludes California, Connecticut, Delaware, District of Columbia, Florida, Hawaii, Illinois, Maryland, Massachusetts, New Hampshire, New Mexico, New York State, North Carolina, Pennsylvania, Vermont, Wisconsin, and Wyoming.
} 
2015 indicate that the majority (56.3\%) had no previous abortions, $35.4 \%$ had one or two previous abortions, and 8.2\% had three or more previous abortions (Table 17). Among the 35 reporting areas ${ }^{\dagger+\dagger^{\dagger \dagger}}$ that provided data for the relevant years of comparison (2006 versus 2015, 2006 versus 2010, 2011 versus 2015, and 2014 versus 2015), the percentage of women who had no previous abortions increased minimally (from $55.6 \%$ to $56.0 \%$ ), whereas there was a $3 \%$ decrease for women who had one or two previous abortions and a 9\% increase for women who had three or more previous abortions from 2006 to 2015. However, the percentage of women who had no previous abortions decreased 1\% from 2006 to 2010 (from $55.6 \%$ to $54.8 \%$ ) and then increased $4 \%$ from 2011 to 2015 (from 53.8\% to 56.0\%). By contrast, the percentage of women who had three or more previous abortions increased $12 \%$ from 2006 to 2010 (from $7.8 \%$ to $8.7 \%$ ) then decreased 9\% from 2011 to 2015 (from 9.3\% to $8.5 \%$ ). The percentage of women who had one or two previous abortions remained stable from 2006 to 2010 (36.6\% to 36.5\%) and then decreased $4 \%$ from 2011 to 2015 (from $36.9 \%$ to $35.5 \%$ ).

\section{Maternal Age and Marital Status by Race/Ethnicity}

In select reporting areas, abortions that were categorized by maternal race and race/ethnicity were further categorized by maternal age and by marital status (Tables 18 and 19). A consistent pattern existed for abortions by maternal age across all race/ethnicity groups, with the smallest percentage of abortions occurring among adolescents aged $<15$ years $(0.2 \%-0.3 \%)$ and the largest percentage occurring among women aged $20-24$ years $(26.5 \%-32.2 \%)$ and $25-29$ years (26.7\%-28.8\%) (Table 19). A consistent pattern also existed for abortions by marital status across all race/ethnicity groups, with a higher percentage of abortions occurring among women who were unmarried $(69.0 \%-91.8 \%)$ than among those who were married (8.2\%-31.0\%) (Table 19). For abortions among married women, the percentage was higher for non-Hispanic women in the other race group $(31.0 \%)$ than for nonHispanic white women (17.0\%), Hispanic (15.6\%) women, or non-Hispanic black women (8.2\%). For abortions among unmarried women, the percentage was higher for non-Hispanic black women (91.8\%) than for non-Hispanic white (83.0\%) women, Hispanic $(84.4 \%)$ women, or non-Hispanic women in the other race group $(69.0 \%)$ (Table 19).

\footnotetext{
$\dagger_{\dagger}+\dagger_{\dagger}$ Excludes California, Connecticut, Delaware, District of Columbia, Florida, Georgia, Hawaii, Illinois, Maryland, Massachusetts, New Hampshire, New Mexico, New York State, North Carolina, Vermont, Wisconsin, and Wyoming.
}

\section{Weeks of Gestation by Maternal Age, Race/Ethnicity, and Method Type}

In certain reporting areas, abortions that were categorized by weeks of gestation were further categorized by maternal age and race/ethnicity (Tables 20 and 21). In every subgroup for these three variables, the largest percentage of abortions occurred at $\leq 8$ weeks' gestation. However, by maternal age, $39.0 \%$ of adolescents aged $<15$ years and $56.7 \%$ of adolescents aged $15-19$ years obtained an abortion by $\leq 8$ weeks' gestation, compared with $63.5 \%-70.5 \%$ of women in older age groups (Figure 3) (Table 20). Conversely, 24.3\% of adolescents aged $<15$ years and $12.3 \%$ of adolescents aged $15-19$ years obtained an abortion after 13 weeks' gestation, compared with $8.0 \%-9.4 \%$ for women in older age groups. By race/ethnicity, $59.1 \%$ of non-Hispanic black women obtained an abortion at $\leq 8$ weeks' gestation, compared with $67.5 \%-70.3 \%$ of women from other race/ethnicity groups. Differences in abortions after 13 weeks' gestation across race/ethnicity groups were less apparent than differences across age groups $(10.5 \%$ for non-Hispanic black women, compared with $8.0 \%-8.5 \%$ for women in the remaining race/ethnicity groups).

Among abortions categorized by weeks of gestation and method type, surgical abortion accounted for the largest percentage of abortions within every gestational age category (Table 22). At $\leq 8$ weeks' gestation, surgical abortion accounted for a smaller percentage of abortions $(64.2 \%)$ than at any other stage of gestation; at 9-20 weeks' gestation, surgical abortion accounted for $94.5 \%-99.2 \%$ of all abortions and at $\geq 21$ weeks' gestation, it accounted for $94.5 \%$ of abortions. By contrast, at $\leq 8$ weeks' gestation, medical abortion accounted for $35.8 \%$ of abortions then decreased to $5.5 \%$ at $9-13$ weeks and $0.7 \%-1.9 \%$ at $14-20$ weeks before increasing to $4.5 \%$ at $\geq 21$ weeks. Throughout gestation, abortions performed by intrauterine instillation or hysterectomy/hysterotomy were rare $(<0.1 \%-0.7 \%$ of abortions).

\section{Abortion Mortality}

Using national data from the Pregnancy Mortality Surveillance System (51), CDC identified six abortion-related deaths for 2014 (Table 23). Investigation of these cases indicated that all six deaths were related to legal abortion and none to illegal abortion.

The annual number of deaths related to legal induced abortion has fluctuated from year to year over the past 40 years (Table 23). For example, nine legal induced abortion-related deaths occurred in 1998, four in 1999, and 11 in 2000. Because of this variability and the relatively limited number of legal induced abortion-related deaths every year, national 
legal abortion case-fatality rates were calculated for consecutive 5-year periods during 1973-2007 and for a consecutive 7-year period during 2008-2014. The national legal induced abortion case-fatality rate for 2008-2014 was 0.62 legal induced abortion-related deaths per 100,000 reported legal abortions. This case-fatality rate was similar to the rate for most of the preceding 5-year periods but lower than the case-fatality rate of 2.09 legal induced abortion-related deaths per 100,000 reported legal abortions for the 5-year period (1973-1977) immediately following nationwide legalization of abortion in 1973. Possible abortion-related deaths that occurred during 2015-2018 are being assessed.

\section{Discussion}

For 2015, a total of 638,169 abortions were reported to CDC by 49 areas. Among these areas, the abortion rate was 11.8 abortions per 1,000 women aged 15-44 years and the abortion ratio was 188 abortions per 1,000 live births. All 49 of these reporting areas submitted data every year during the period of analysis from 2006 to 2015, thus providing the information necessary for evaluating trends. Among these areas, the number, rate, and ratio of reported abortions decreased $2 \%$ from 2014 to 2015, which, in combination with decreases that occurred during previous years (11-15), resulted in the lowest values for all three measures for the entire period of analysis. Among areas that reported by age every year of the analysis, women in their 20s accounted for the majority of abortions $(57 \%-59 \%)$ and had the highest abortion rates, whereas decreases in the abortion rate were greater for adolescents aged $<20$ years than for any other age group. In addition, throughout the period of analysis, $\leq 9 \%$ of abortions each year were performed after 13 weeks' gestation; approximately two thirds of abortions were performed at $\leq 8$ weeks' gestation, and this percentage increased from $63.5 \%$ in 2006 to $65.4 \%$ in 2015. Among areas that included medical abortion on their reporting form every year, the percentage of all abortions performed by early medical abortion increased from $11.3 \%$ in 2006 to $24.2 \%$ in 2015 .

These findings underscore important maternal age differences in abortion trends. Because of the high rate and proportion of abortions that occurred among women in their 20 s, women in this age group have contributed substantially to overall changes. Conversely, during 2006-2015, women aged $\geq 40$ years had consistently low abortion rates and accounted for a limited percentage of abortions $(\leq 3.7 \%)$; therefore, they have had a much smaller contribution to overall abortion trends. Nonetheless, among women aged $\geq 40$ years, the abortion ratio continues to be higher than among women in their mid to late
20 s and 30s. Because of the limited proportion of abortions that are performed later in gestation among women aged $\geq 40$ years, which might be completed for maternal medical indications or fetal anomalies, the continuing high abortion ratio among these older women suggests that unintended pregnancy is a problem that women encounter throughout their reproductive years (52).

The adolescent abortion trends described in this report are important for monitoring progress that has been made toward reducing adolescent pregnancies in the United States. National birth data indicate the birth rate for adolescents aged 15-19 years decreased 47\% during 2006-2015 (53,54), compared with a $54 \%$ decrease in the abortion rate for adolescents aged 15-19 years during the same period. Recent national birth data indicate the birth rate decreased an additional 16\% from 2015 to 2017 (55,56). These findings indicate that declines in adolescent pregnancies in the United States have been accompanied by large decreases in both adolescent births and abortions and that the pattern of decline is continuing (53-56).

The findings in this report indicate that the number, rate, and ratio of reported abortions have declined across all race/ ethnicity groups but that well-documented disparities persist $(3,4,17-22)$. In this report, abortion rates and ratios remained 1.5 and 1.3 times higher for Hispanic compared with nonHispanic white women and 3.6 and 3.5 times higher for non-Hispanic black compared with non-Hispanic white women. The comparatively high abortion rates and ratios among non-Hispanic black women have been attributed to higher unintended pregnancy rates and a greater percentage of unintended pregnancies ending in abortion (52). Data from certain reports suggest that differences in abortion indicators between non-Hispanic black women and women of other groups narrowed from 1994 to 2008 (4,21), but remained steady from 2008 to 2014 (22).

The findings in this report indicate the majority of women obtaining abortions do so early in gestation ( $\leq 8$ weeks), when the risks for complications are lowest (57-60). Among the areas that reported gestational age data every year during 2006-2015, the percentage of abortions performed at $\leq 8$ weeks' gestation increased $3 \%$. Moreover, among the areas that reported abortions at $\leq 13$ weeks' gestation by individual week, the distribution continued to shift toward earlier weeks of gestation, with the percentage of early abortions performed at $\leq 6$ weeks' gestation increasing 11\% from 2006 to 2015 . Nonetheless, the overall percentage of abortions performed at $\leq 13$ weeks' gestation was stable during 2006-2015. Reports indicate that delays in obtaining an abortion are more common among certain groups of women (61-63); among women obtaining abortions in this report, a smaller percentage of adolescents aged $\leq 19$ years and non-Hispanic black women, 
compared with women in other age and race/ethnicity groups, obtained abortions at $\leq 8$ weeks' gestation. Because of the small but persistent percentage of women who obtain abortions at $>13$ weeks' gestation, a better understanding is needed of how to address delays in obtaining abortions $(61,63-66)$.

The trend of obtaining abortions earlier in pregnancy has been facilitated by changes in abortion practices. Research conducted in the United States during the 1970s indicated that surgical abortion procedures performed at $\leq 6$ weeks' gestation, compared with 7-12 weeks' gestation, were less likely to result in successful termination of the pregnancy (67). However, subsequent advances in technology (e.g., improved transvaginal ultrasonography and sensitive pregnancy tests) have allowed very early surgical abortions to be performed with completion rates exceeding $97 \%(68-70)$. Likewise, the development of early medical abortion regimens has allowed for abortions to be performed very early in gestation, with completion rates for regimens that combine mifepristone and misoprostol reaching $96 \%-98 \%(71)$. In 2015, 65.4\% of all reported abortions were performed at $\leq 8$ completed weeks' gestation; thus, the women receiving these abortions were eligible for early medical abortion (a nonsurgical abortion at $\leq 8$ weeks' gestation) on the basis of gestational age; $35.8 \%$ of abortions at $\leq 8$ weeks' gestation and $24.6 \%$ of all abortions were reported as early medical abortions, with the proportion of all abortions reported as early medical abortion up from $11.3 \%$ in 2006. Moreover, in addition to abortions meeting the definition of early medical abortion, the percentage of abortions at 9 weeks' gestation reported as medical has increased in recent years (from 5.0\%-7.7\% during 2011-2014 to $13.0 \%$ in 2015). On the basis of evidence that early medical abortion is safe and effective beyond 63 days' gestation (44), professional clinical practice guidelines were updated midyear in 2013 and 2014 to extend the gestational age eligibility for early medical abortion from 63 to 70 days ( $\leq 9$ completed weeks) $(45,46)$. In early 2016, FDA updated its approval for use of mifepristone for early medical abortions, extending the gestational age limit to 70 days (47). CDC will continue to monitor medical abortions at 9 weeks' gestation.

The annual number of deaths related to legal induced abortion has fluctuated from year to year over the past 40 years. Because of this variability and the relatively limited number of abortionrelated deaths every year, national legal abortion case-fatality rates were calculated for consecutive 5-year periods during 1973-2007 and for a consecutive 7-year period during 2008-2014. The national legal induced abortion case-fatality rate for 2008-2014 was similar to the case-fatality rate for most of the preceding 5 -year periods but was much lower than the case-fatality rate for the 5-year period (1973-1978) that immediately followed nationwide legalization of abortion in 1973.

\section{Limitations}

The findings in this report are subject to at least four limitations. First, because reporting to CDC is voluntary and reporting requirements are established by the individual reporting areas (24), CDC is unable to obtain the total number of abortions performed in the United States. Although most reporting areas collect and send abortion data to $\mathrm{CDC}$, three of the 52 reporting areas (California, Maryland, and New Hampshire) did not provide CDC data for 2006-2015 on a consistent annual basis. During the period covered by this report, the total annual number of abortions reported to CDC was $68 \%-71 \%$ of the number recorded by the Guttmacher Institute through a national census of abortion providers $(8,9,16)$. $\$ \$ \$ \$ \$ S$ In addition, whereas most reporting areas that send abortion data to CDC have laws requiring medical providers to submit a report for every abortion they perform to a central health agency, in New Jersey and DC medical providers submit this information voluntarily (23). As a result, the abortion numbers these areas report to CDC are likely incomplete.99999 Moreover, even in states that legally require medical providers to submit a report for all the abortions they perform, enforcement of this requirement varies, and as a consequence, numbers from multiple other reporting areas are likely incomplete as well. ${ }^{* * * * * *}$

Second, because reporting requirements are established by the individual reporting areas, many states use reporting forms that differ from the technical standards and guidance CDC developed in collaboration with the National Association for Public Health Statistics and Information Systems. Consequently, many reporting areas do not collect all the information CDC compiles on the characteristics of women obtaining abortions (e.g., maternal age, race, and ethnicity) or do not report the data in a manner consistent with this guidance (e.g., gestational age). Although missing demographic information can reduce the extent to which the statistics in

\footnotetext{
\$SSSS In 2014, the most recent year for which the Guttmacher Institute has published data, abortions performed in California, Maryland, and New Hampshire accounted for $20 \%$ of the 926,200 abortions counted through the Guttmacher Institute's national census of abortion providers (16).

99999 In 2014, the abortion numbers that CDC obtained from the District of Columbia and New Jersey were $48 \%$ and $54 \%$, respectively, of the abortion numbers that the Guttmacher Institute obtained for these areas through their national census of abortion providers (16).

****** In 2014, the abortion numbers CDC obtained for Wyoming were $<5 \%$ of the numbers obtained for this state by the Guttmacher Institute through their national census of abortion providers. CDC numbers for Hawaii were $57 \%$ of the Guttmacher Institute numbers. CDC numbers for Colorado, Connecticut, Nevada, New York (city and state combined), North Carolina, Oregon, Rhode Island, Tennessee, West Virginia, and Vermont were $74 \%-<90 \%$ of the Guttmacher Institute numbers. All other areas with legal reporting requirements that provided data to CDC obtained numbers that were at least $90 \%$ of the Guttmacher Institute numbers (16).
} 
this report represent all women in the United States, five nationally representative surveys of women obtaining abortions in 1987, 1994-1995, 2001-2002, 2008, and 2014 (17-20,22) produced percentage distributions for most characteristics that are nearly identical to the percentage distributions reported by CDC. The exception is the percentage distribution of abortions by race/ethnicity. The percentage of abortions accounted for by non-Hispanic black women is higher and by Hispanic women is lower in this report than the percentages reported from a recent nationally representative survey of women obtaining abortions (22). Differences might be attributable to the fact that the number of states that report to CDC by race/ethnicity continues to be somewhat lower than for other demographic variables. Certain reporting areas that have not reported to CDC or have not reported cross-classified race/ethnicity data (e.g., California, Florida, and Illinois) have sufficiently large populations of minority women that the absence of data from these areas reduces the representativeness of CDC data.

In addition, certain areas collect gestational age on the basis of estimated date of conception or collect probable postfertilization age. Without medical guidance on how to report these data, the validity and reliability of gestational age for these reporting areas is uncertain.

Despite challenges in capturing medical abortions for reporting $(8,16,23,72)$, a comparison of CDC data with mifepristone sales data ${ }^{\dagger \dagger}+\dagger^{\dagger}$ suggests that CDC's Abortion Surveillance System accurately describes the use of early medical abortion relative to other abortion methods in the United States (73). However, because of recent changes in clinical practice guidelines for the use of mifepristone and misoprostol through 9 completed weeks of gestation, CDC's current definition of early medical abortion does not represent abortions performed through this method. Nonetheless, for 2015, of the medical abortions reported at $\leq 9$ weeks, only $5.4 \%$ were performed at 9 weeks, and CDC continues to monitor these changes in clinical practice.

Third, abortion data are compiled and reported to CDC by the central health agency of the reporting area in which the abortion was performed rather than the reporting area in which the woman lived. Thus, the available population (32-41) and birth data (42), which are organized by the states in which women live, differ in certain cases from the population of women who undergo abortions in a given reporting area. This likely results in an overestimation of abortions for reporting

\footnotetext{
$\overline{f+\uparrow \dagger \dagger \dagger}$ Because the sole distributor of mifepristone in the United States only sells this medication to licensed physicians, who must sign and return a prescriber's agreement, sales data from this company are not limited by individual state reporting requirements or the difficulties of identifying smaller providers within the wider medical community.
}

areas in which a high percentage of abortions are obtained by out-of-state residents and an underestimation of abortions for states where residents frequently obtain abortions out of state. Limited abortion services, more stringent regulatory requirements for obtaining an abortion, or geographic proximity to services in another state might influence where women obtain abortion services. To examine these reporting biases, CDC attempts to categorize abortions by residence in addition to geographic occurrence. However, in 2015, CDC was unable to identify the reporting area, territory, or country of residence for $12.7 \%$ of reported abortions.

Finally, because reporting areas provide CDC with aggregate numbers, not individual-level data, and because available demographic information is limited by what reporting areas collect on their reporting forms, it is not possible to perform stratified analyses by additional demographic variables (e.g., socioeconomic status).

\section{Public Health Implications}

Ongoing surveillance of legal induced abortion is important for several reasons. First, abortion surveillance is needed to guide and evaluate the success of programs aimed at preventing unintended pregnancies. Although pregnancy intentions can be difficult to assess (74-79), abortion surveillance provides an important measure of pregnancies that are unwanted. Second, routine abortion surveillance is needed to assess trends in clinical practice patterns over time. Information in this report on the number of abortions performed through different methods (e.g., medical or surgical) and at different gestational ages provides the denominator data that are necessary for analyses of the relative safety of abortion practices (80). Finally, information on the number of pregnancies ending in abortion is needed in conjunction with data on births and fetal losses to more accurately estimate the number of pregnancies in the United States and determine rates for various outcomes of public health importance (e.g., adolescent pregnancies) (81).

According to the most recent national estimates from 2010, $18 \%$ of all pregnancies in the United States end in induced abortion (82). Multiple factors influence the incidence of abortion, including access to health care services and contraception (83-85); the availability of abortion providers $(8,9,16,86-89)$; state regulations, such as mandatory waiting periods (66), parental involvement laws (90), and legal restrictions on abortion providers $(91,92)$; increasing acceptance of nonmarital childbearing $(93,94)$; shifts in the race/ethnicity composition of the U.S. population (95,96); and changes in the economy and the resulting impact on fertility preferences and use of contraception $(97,98)$. However, despite 
the multiple influences on abortion, because unintended pregnancy precedes nearly all cases of abortions, ${ }^{\$ S \$ S \$ \$}$ efforts to help women avoid pregnancies that they do not desire might reduce the number of abortions (83-85).

Recent data indicate that the proportion of pregnancies in the United States that were unintended decreased from 51\% in 2008 to $45 \%$ during 2011-2013, after a slight increase from 2001 to 2008 (52). Changing patterns of contraception use might have contributed to this decrease in unintended pregnancy. The use of the most effective forms of reversible contraception (i.e., intrauterine devices and hormonal implants) (99) has recently increased among all women (100-103), and the use of contraception overall appears to be increasing among adolescents (104). Of reported abortions in 2015 , the majority were among women with a previous birth, and a substantial proportion occurred among women with a previous induced abortion, events that are also opportunities for contraception counseling. Contraception provision in the immediate postpartum and postabortion settings might increase access to these methods at a time when women are receiving health services. In addition, providing contraception for women at no cost can increase use of these methods and reduce abortion rates $(83-85,105)$. Insufficient provider reimbursement and training, inadequate client-centered counseling, lack of youth-friendly services, and low client awareness of available contraceptive methods are also barriers to accessing contraception (106-109). Removing these barriers might help improve contraceptive use, potentially reducing the number of unintended pregnancies and the number of abortions performed in the United States.

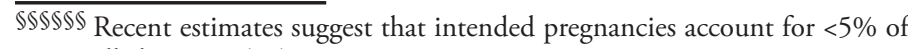
all abortions (31).
}

\section{Conflict of Interest}

No conflicts of interest reported.

\section{References}

1. Smith JC. Abortion surveillance report, hospital abortions, annual summary 1969. Atlanta, GA: US Department of Health, Education, and Welfare, Public Health Service, Health Services and Mental Health Administration, National Communicable Disease Center; 1970.

2. Gamble SB, Strauss LT, Parker WY, Cook DA, Zane SB, Hamdan S. Abortion surveillance-United States, 2005. MMWR Surveill Summ 2008;57(No. SS-13).

3. Henshaw SK, Kost K. Trends in the characteristics of women obtaining abortions, 1974-2004. New York, NY: Guttmacher Institute; 2008. http://www.guttmacher.org/pubs/2008/09/23/TrendsWomenAbortionswTables.pdf

4. Jones RK, Kost K, Singh S, Henshaw SK, Finer LB. Trends in abortion in the United States. Clin Obstet Gynecol 2009;52:119-29. https://doi. org/10.1097/GRF.0b013e3181a2af8f
5. Pazol K, Gamble SB, Parker WY, Cook DA, Zane SB, Hamdan S. Abortion surveillance-United States, 2006. MMWR Surveill Summ 2009;58(No. SS-8).

6. Pazol K, Zane S, Parker WY, et al. Abortion surveillance-United States, 2007. MMWR Surveill Summ 2011;60(No. SS-1).

7. Pazol K, Zane SB, Parker WY, Hall LR, Berg C, Cook DA. Abortion surveillance-United States, 2008. MMWR Surveill Summ 2011;60(No. SS-15).

8. Jones RK, Kooistra K. Abortion incidence and access to services in the United States, 2008. Perspect Sex Reprod Health 2011;43:41-50. https://doi.org/10.1363/4304111

9. Jones RK, Jerman J. Abortion incidence and service availability in the United States, 2011. Perspect Sex Reprod Health 2014;46:3-14. https:// doi.org/10.1363/46e0414

10. Pazol K, Creanga AA, Zane SB, Burley KD, Jamieson DJ. Abortion surveillance-United States, 2009. MMWR Surveill Summ 2012;61(No. SS-8).

11. Pazol K, Creanga AA, Burley KD, Hayes B, Jamieson DJ. Abortion surveillance-United States, 2010. MMWR Surveill Summ 2013;62(No. SS-8).

12. Pazol K, Creanga AA, Burley KD, Jamieson DJ. Abortion surveillanceUnited States, 2011. MMWR Surveill Summ 2014;63(No. SS-11).

13. Pazol K, Creanga AA, Jamieson DJ. Abortion Surveillance-United States, 2012. MMWR Surveill Summ 2015;64(No. SS-10). https://doi. org/10.15585/ss6410a 1

14. Jatlaoui TC, Ewing A, Mandel MG, et al. Abortion Surveillance-United States, 2013. MMWR Surveill Summ 2016;65(No. SS-12). https://doi. org/10.15585/mmwr.ss6512a1

15. Jatlaoui TC, Shah J, Mandel MG, et al. Abortion Surveillance-United States, 2014. MMWR Surveill Summ 2017;66(No. SS-24):1-48 https:// doi.org/10.15585/mmwr.ss6624a1

16. Jones RK, Jerman J. Abortion incidence and service availability in the United States, 2014. Perspect Sex Reprod Health 2017;49:17-27. https://doi.org/10.1363/psrh.12015

17. Henshaw SK, Kost K. Abortion patients in 1994-1995: characteristics and contraceptive use. Fam Plann Perspect 1996;28:140-7, 158. https://www.guttmacher.org/journals/psrh/1996/07/abortionpatients-1994-1995-characteristics-and-contraceptive-use https://doi. org/10.2307/2136189

18. Henshaw SK, Silverman J. The characteristics and prior contraceptive use of U.S. abortion patients. Fam Plann Perspect 1988;20:158-68. https://doi.org/10.2307/2135791

19. Jones RK, Darroch JE, Henshaw SK. Patterns in the socioeconomic characteristics of women obtaining abortions in 2000-2001. Perspect Sex Reprod Health 2002;34:226-35. https://doi.org/10.2307/3097821

20. Jones RK, Finer LB, Singh S. Characteristics of U.S. abortion patients, 2008. New York, NY: Guttmacher Institute; 2010. http://www. guttmacher.org/pubs/US-Abortion-Patients.pdf

21. Jones RK, Kavanaugh ML. Changes in abortion rates between 2000 and 2008 and lifetime incidence of abortion. Obstet Gynecol 2011;117:1358-66. https://doi.org/10.1097/AOG.0b013e31821c405e

22. Jerman J, Jones RK, Onda T. Characteristics of U.S. abortion patients in 2014 and changes since 2008. New York, NY: Guttmacher Institute; 2016. https://www.guttmacher.org/sites/default/files/report_pdf/ characteristics-us-abortion-patients-2014.pdf

23. Guttmacher Institute. Abortion reporting requirements. New York, NY: Guttmacher Institute; 2018. https://www.guttmacher.org/state-policy/ explore/abortion-reporting-requirements

24. Saul R. Abortion reporting in the United States: an examination of the federal-state partnership. Fam Plann Perspect 1998;30:244-7. https:// doi.org/10.2307/2991612

25. CDC. Guide to completing the facility worksheets for the certificate of live birth and report of fetal death. Hyattsville, MD: CDC National Center for Health Statistics; 2016. https://www.cdc.gov/nchs/data/dvs/ GuidetoCompleteFacilityWks.pdf 
26. Speroff L, Fritz MA. Clinical gynecologic endocrinology and infertility. Philadelphia, PA: Lippincott Williams \& Wilkins; 2005.

27. American College of Obstetricians and Gynecologists. Practice bulletin no. 143: medical management of first-trimester abortion. Obstet Gynecol 2014;123:676-92. https://doi.org/10.1097/01. AOG.0000444454.67279.7d

28. Paul M, Lichtenberg ES, Borgatta L, Grimes DA, Stubblefield PG, Creinin MD. Management of unintended and abnormal pregnancy: comprehensive abortion care. Oxford, England: Blackwell Publishing Ltd.; 2009.

29. Grimes DA, Schultz KF, Cates W Jr, Tyler CW. The Joint Program for the Study of Abortion/CDC: a preliminary report. In: Hern WM, Andrikopoulos B, eds. Abortion in the seventies: proceedings of the Western Regional Conference on Abortion. New York, NY: National Abortion Federation; 1977;41-54.

30. Grimes DA, Schulz KF, Cates W Jr, Tyler CW Jr. Mid-trimester abortion by dilatation and evacuation: a safe and practical alternative. N Engl J Med 1977;296:1141-5. https://doi.org/10.1056/NEJM197705192962004

31. Kost K. Unintended pregnancy rates at the state level: estimates for 2010 and trends since 2002. New York, NY: Guttmacher Institute; 2015. http://www.guttmacher.org/pubs/StateUP10.pdf

32. CDC. Vintage 2015 bridged-race postcensal population estimates. [File pcen_v2015_y15.sasbdat]. Hyattsville, MD: CDC, National Center for Health Statistics; 2016.

33. CDC. Vintage 2014 bridged-race postcensal population estimates. [File pcen_v2014_y14.sasbdat]. Hyattsville, MD: CDC, National Center for Health Statistics; 2015. https://www.cdc.gov/nchs/nvss/bridged_race/ data_documentation.htm\#vintage 2015

34. CDC. Vintage 2013 bridged-race postcensal population estimates [File pcen_v2013_y13.sasbdat]. Hyattsville, MD: CDC, National Center for Health Statistics; 2014. https://www.cdc.gov/nchs/nvss/bridged_race/ data_documentation.htm\#vintage2013

35. CDC. Vintage 2012 bridge-race postcensal population estimates [File pcen_v2012_y12.sasbdat]. Hyattsville, MD: CDC, National Center for Health Statistics; 2013. https://www.cdc.gov/nchs/nvss/bridged_race/ data_documentation.htm\#vintage 2012

36. CDC. Vintage 2011 bridge-race postcensal population estimates. [File pcen_v2011_y11.sasbdat]. Hyattsville, MD: CDC, National Center for Health Statistics; 2012. https://www.cdc.gov/nchs/nvss/bridged_race/ data_documentation.htm\#vintage2011

37. CDC. Bridged-race population estimates, April 1, 2010. [File census_0401_2010.sas7bdat.zip]. Hyattsville, MD: CDC, National Center for Health Statistics; 2011. https://www.cdc.gov/nchs/nvss/ bridged_race/data_documentation.htm\#april2010

38. CDC. July 1, 2000-July 2009 revised bridged-race intercensal population estimates. [File icen_2000_09_y09.sas.zip]. Hyattsville, MD: CDC, National Center for Health Statistics; 2012. https://www.cdc.gov/nchs/ nvss/bridged_race/data_documentation.htm\#april2019

39. CDC. July 1, 2000-July 2009 revised bridged-race intercensal population estimates. [File icen_2000_09_y08.sas.zip]. Hyattsville, MD: CDC, National Center for Health Statistics; 2012. https://www.cdc.gov/nchs/ nvss/bridged_race/data_documentation.htm\#july2009

40. CDC. July 1, 2000-July 2009 revised bridged-race intercensal population estimates. [File icen_2000_09_y07.sas.zip]. Hyattsville, MD: CDC, National Center for Health Statistics; 2012. https:/www.cdc.gov/nchs/ nvss/bridged_race/data_documentation.htm\#july2009

41. CDC. July 1, 2000-July 2009 revised bridged-race intercensal population estimates. [File icen_2000_09_y06sas.zip]. Hyattsville, MD: CDC, National Center for Health Statistics; 2012. https://www.cdc.gov/nchs/ nvss/bridged_race/data_documentation.htm\#july2009

42. CDC. Natality files. Hyattsville, MD: CDC, National Center for Health Statistics; 2018 https://wonder.cdc.gov/Natality.html

43. Hoyert DL. Maternal mortality and related concepts. Vital Health Stat 3 2007;33:1-13 http://www.cdc.gov/nchs/data/series/sr_03/sr03_033.pdf
44. Winikoff B, Dzuba IG, Chong E, et al. Extending outpatient medical abortion services through 70 days of gestational age. Obstet Gynecol 2012;120:1070-6.

45. National Abortion Federation. Clinical policy guidelines. Washington, DC: National Abortion Federation; 2013. https://www.prochoice.org/ pubs_research/publications/documents/2013NAFCPGsforweb.pdf

46. Society of Family Planning. Medical management of first-trimester abortion. Contraception 2014;89:148-61. https://doi.org/10.1016/j. contraception.2014.01.016

47. Food and Drug Administration. Mifeprex (Mifepristone) information. Silver Spring, MD: Food and Drug Administration; 2016. https://www.fda.gov/Drugs/ DrugSafety/PostmarketDrugSafetyInformationforPatientsandProviders/ ucm111323.htm

48. CDC. Abortion surveillance, 1972. Atlanta, GA: US Department of Health, Education, and Welfare, Public Health Service, CDC; 1974.

49. CDC. Abortion surveillance, 1977. Atlanta, GA: US Department of Health, Education, and Welfare, Public Health Service, CDC; 1979.

50. CDC. Pregnancy-related deaths. Atlanta, GA: US Department of Health and Human Services, CDC; 2015. http://www.cdc.gov/ reproductivehealth/MaternalInfantHealth/Pregnancy-relatedMortality.htm

51. Zane S, Creanga AA, Berg CJ, et al. Abortion-related mortality in the United States: 1998-2010. Obstet Gynecol 2015;126:258-65. https:// doi.org/10.1097/AOG.0000000000000945

52. Finer LB, Zolna MR. Declines in unintended pregnancy in the United States, 2008-2011. N Engl J Med 2016;374:843-52. https://doi. org/10.1056/NEJMsa1506575

53. Martin JA, Hamilton BE, Sutton PD, et al. Births: final data for 2006. Natl Vital Stat Rep 2009;57:1-102. https://www.cdc.gov/nchs/data/ nvsr/nvsr57/nvsr57_07.pdf

54. Martin JA, Hamilton BE, Osterman MJ, Driscoll AK, Mathews TJ. Births: final data for 2015. Natl Vital Stat Rep 2017;66:1.

55. Martin JA, Hamilton BE, Osterman MJK, Driscoll AK, Drake P. Births: final data for 2016. Natl Vital Stat Rep 2018;67:1-55.

56. Martin JAHB, Hamilton BE, Osterman MJK. Births in the United States, 2016. NCHS Data Brief 2017;287:1-8.

57. Bartlett LA, Berg CJ, Shulman HB, et al. Risk factors for legal induced abortion-related mortality in the United States. Obstet Gynecol 2004;103:729-37. https://doi.org/10.1097/01. AOG.0000116260.81570.60

58. Buehler JW, Schulz KF, Grimes DA, Hogue CJ. The risk of serious complications from induced abortion: do personal characteristics make a difference? Am J Obstet Gynecol 1985;153:14-20. https://doi. org/10.1016/0002-9378(85)90582-4

59. Ferris LE, McMain-Klein M, Colodny N, Fellows GF, Lamont J. Factors associated with immediate abortion complications. CMAJ 1996; 154:1677-85.

60. Lichtenberg ES, Paul M; Society of Family Planning. Surgical abortion prior to 7 weeks of gestation. Contraception 2013;88:7-17. https://doi. org/10.1016/j.contraception.2013.02.008

61. Foster DG, Kimport K. Who seeks abortions at or after 20 weeks? Perspect Sex Reprod Health 2013;45:210-8. https://doi. org/10.1363/4521013

62. Jones RK, Finer LB. Who has second-trimester abortions in the United States? Contraception 2012;85:544-51. https://doi.org/10.1016/j. contraception.2011.10.012

63. Kiley JW, Yee LM, Niemi CM, Feinglass JM, Simon MA. Delays in request for pregnancy termination: comparison of patients in the first and second trimesters. Contraception 2010;81:446-51. https://doi. org/10.1016/j.contraception.2009.12.021

64. Drey EA, Foster DG, Jackson RA, Lee SJ, Cardenas LH, Darney PD. Risk factors associated with presenting for abortion in the second trimester. Obstet Gynecol 2006;107:128-35. https://doi.org/10.1097/01. AOG.0000189095.32382.d0 
65. Finer LB, Frohwirth LF, Dauphinee LA, Singh S, Moore AM. Timing of steps and reasons for delays in obtaining abortions in the United States. Contraception 2006;74:334-44. https://doi.org/10.1016/j. contraception.2006.04.010

66. Joyce TJ, Henshaw SK, Dennis A, Finer LB, Blanchard K. The impact of state mandatory counseling and waiting period laws on abortion: a literature review. New York, NY: Guttmacher Institute; 2009. http:// www.guttmacher.org/pubs/MandatoryCounseling.pdf

67. Kaunitz AM, Rovira EZ, Grimes DA, Schulz KF. Abortions that fail. Obstet Gynecol 1985;66:533-7.

68. Creinin MD, Edwards J. Early abortion: surgical and medical options. Curr Probl Obstet Gynecol Fertil 1997;20:1-32. https://ucdavis.pure.elsevier. $\mathrm{com} / \mathrm{en} /$ publications/early-abortion-surgical-and-medical-options

69. Edwards J, Carson SA. New technologies permit safe abortion at less than six weeks' gestation and provide timely detection of ectopic gestation. Am J Obstet Gynecol 1997;176:1101-6. https://doi. org/10.1016/S0002-9378(97)70410-1

70. Paul ME, Mitchell CM, Rogers AJ, Fox MC, Lackie EG. Early surgical abortion: efficacy and safety. Am J Obstet Gynecol 2002;187:407-11. https://doi.org/10.1067/mob.2002.123898

71. Paul M, Stewart FH. Abortion. In: Hatcher RA, Trussell J, Nelson AL, Cates Jr. W, Stewart F, Kowal D, eds. Contraceptive technology, 19th rev. ed. New York, NY: Ardent Media, Inc.; 2008; 637-72.

72. Yunzal-Butler C, Sackoff J, Li W. Medication abortions among New York City residents, 2001-2008. Perspect Sex Reprod Health 2011;43:218-23. https://doi.org/10.1363/4321811

73. Pazol K, Creanga AA, Zane SB. Trends in use of medical abortion in the United States: reanalysis of surveillance data from the Centers for Disease Control and Prevention, 2001-2008. Contraception 2012;86:746-51. https://doi.org/10.1016/j.contraception.2012.05.023

74. Klerman LV. The intendedness of pregnancy: a concept in transition. Matern Child Health J 2000;4:155-62. https://doi. org/10.1023/A:1009534612388

75. Lifflander A, Gaydos LM, Hogue CJ. Circumstances of pregnancy: low income women in Georgia describe the difference between planned and unplanned pregnancies. Matern Child Health J 2007;11:81-9. https:// doi.org/10.1007/s10995-006-0138-3

76. Sable MR, Wilkinson DS. Pregnancy intentions, pregnancy attitudes, and the use of prenatal care in Missouri. Matern Child Health J 1998;2:155-65. https://doi.org/10.1023/A:1021827110206

77. Santelli J, Rochat R, Hatfield-Timajchy K, et al; Unintended Pregnancy Working Group. The measurement and meaning of unintended pregnancy. Perspect Sex Reprod Health 2003;35:94-101.

78. Santelli JS, Lindberg LD, Orr MG, Finer LB, Speizer I. Toward a multidimensional measure of pregnancy intentions: evidence from the United States. Stud Fam Plann 2009;40:87-100. https://doi. org/10.1111/j.1728-4465.2009.00192.x

79. Trussell J, Vaughan B, Stanford J. Are all contraceptive failures unintended pregnancies? Evidence from the 1995 National Survey of Family Growth. Fam Plann Perspect 1999;31:246-7, 260 https://www. guttmacher.org/journals/psrh/1999/09/are-all-contraceptive-failuresunintended-pregnancies-evidence-1995-national. https://doi. org/10.2307/2991573

80. National Academies of Sciences Engineering and Medicine. The safety and quality of abortion care in the United States. Washington, DC: The National Academies Press; 2018. https://doi.org/10.17226/24950

81. Kost K, Maddow-Zimet I, Arpaia A. Pregnancies, births and abortions among adolescents and young women in the United States, 2013: National and state trends by age, race and ethnicity. New York, NY: Guttmacher Institute; 2017. https://www.guttmacher.org/sites/default/ files/report_pdf/us-adolescent-pregnancy-trends-2013.pdf

82. Curtin SC, Abma JC, Kost K. 2010 pregnancy rates among U.S. women. NCHS Health E-Stat; December 2015. https://www.cdc.gov/nchs/data/ hestat/pregnancy/2010_pregnancy_rates.htm
83. Peipert JF, Madden T, Allsworth JE, Secura GM. Preventing unintended pregnancies by providing no-cost contraception. Obstet Gynecol 2012;120:1291-7. https://doi.org/10.1097/AOG.0b013e318273eb56

84. Biggs MA, Rocca CH, Brindis CD, Hirsch H, Grossman D. Did increasing use of highly effective contraception contribute to declining abortions in Iowa? Contraception 2015;91:167-73. https://doi. org/10.1016/j.contraception.2014.10.009

85. Ricketts S, Klingler G, Schwalberg R. Game change in Colorado: widespread use of long-acting reversible contraceptives and rapid decline in births among young, low-income women. Perspect Sex Reprod Health 2014;46:125-32. https://doi.org/10.1363/46e1714

86. Finer LB, Henshaw SK. Abortion incidence and services in the United States in 2000. Perspect Sex Reprod Health 2003;35:6-15.

87. Henshaw SK. Abortion incidence and services in the United States, 1995-1996. Fam Plann Perspect 1998;30:263-70, 287. https://doi. org/10.2307/2991501

88. Jones RK, Zolna MR, Henshaw SK, Finer LB. Abortion in the United States: incidence and access to services, 2005. Perspect Sex Reprod Health 2008;40:6-16. https://doi.org/10.1363/4000608

89. Quast T, Gonzalez F, Ziemba R. Abortion facility closings and abortion rates in Texas. Inquiry 2017;54:46958017700944. https://doi. org/10.1177/0046958017700944

90. Dennis A, Henshaw SK, Joyce TJ, Finer LB, Blanchard K. The impact of laws requiring parental involvement for abortion: a literature review. New York, NY: Guttmacher Institute; 2009. http://www.guttmacher. org/pubs/ParentalInvolvementLaws.pdf

91. Grossman D, Baum S, Fuentes L, et al. Change in abortion services after implementation of a restrictive law in Texas. Contraception 2014;90:496-501. https://doi.org/10.1016/j.contraception.2014.07.006

92. Joyce T. The supply-side economics of abortion. N Engl J Med 2011;365:1466-9. https://doi.org/10.1056/NEJMp1109889

93. Martinez GM, Chandra A, Abma JC, Jones J, Mosher WD. Fertility, contraception, and fatherhood: data on men and women from cycle 6 (2002) of the 2002 National Survey of Family Growth. Vital Health Stat 23 2006;26:1-142.

94. Ventura SJ. Changing patterns of nonmarital childbearing in the United States. NCHS Data Brief 2009;18:1-8.

95. Moore KA. Teen births: examining the recent increase. Washington DC: The National Campaign to Prevent Teen and Unplanned Pregnancy; 2009. http://www.childtrends.org/wp-content/ uploads/2009/03/Child_Trends_2009_03_13_FS_TeenBirthRate.pdf

96. Yang Z, Gaydos LM. Reasons for and challenges of recent increases in teen birth rates: a study of family planning service policies and demographic changes at the state level. J Adolesc Health 2010;46:517-24. https://doi.org/10.1016/j.jadohealth.2010.03.021

97. American College of Obstetricians and Gynecologists. Bad economy blamed for women delaying pregnancy and annual check-up. Washington, DC: American College of Obstetricians and Gynecologists; 2009.

98. Guttmacher Institute. A real-time look at the impact of the recession on women's family planning and pregnancy decisions. New York, NY: Guttmacher Institute; 2009. http://www.guttmacher.org/pubs/ RecessionFP.pdf

99. Trussell J. Contraceptive efficacy. In: Hatcher R, Trussell J, Nelson A, Cates W, Kowal D, Policar M, eds. Contraceptive technology, 20th ed. Atlanta, GA: Ardent Media, Inc; 2011;779-88. 
100. Kavanaugh ML, Jerman J; ML K. Contraceptive method use in the United States: trends and characteristics between 2008, 2012 and 2014. Contraception 2018;97:14-21. https://doi.org/10.1016/j. contraception.2017.10.003

101. Daniels K, Daugherty J, Jones J. Current contraceptive status among women aged 15-44: United States, 2011-2013. NCHS Data Brief 2014;173:1-8.

102. Abma JC, Martinez GM. Sexual activity and contraceptive use among teenagers in the United States, 2011-2015. Natl Health Stat Report 2017;104:1-23.

103. Kann L, McManus T, Harris WA, et al. Youth risk behavior surveillance-United States, 2015. MMWR Surveill Summ 2016;65:1174. https://doi.org/10.15585/mmwr.ss6506a1

104. Lindberg LD, Santelli JS, Desai S. Changing patterns of contraceptive use and the decline in rates of pregnancy and birth among U.S. adolescents, 2007-2014. J Adolesc Health 2018;63:253-6. https:// doi.org/10.1016/j.jadohealth.2018.05.017

105. Goyal V, Canfield C, Aiken AR, Dermish A, Potter JE. Postabortion contraceptive use and continuation when long-acting reversible contraception is free. Obstet Gynecol 2017;129:655-62. https://doi. org/10.1097/AOG.0000000000001926
106. Boulet SL, D’Angelo DV, Morrow B, et al. Contraceptive use among nonpregnant and postpartum women at risk for unintended pregnancy, and female high school students, in the context of Zika preparednessUnited States, 2011-2013 and 2015. MMWR Morb Mortal Wkly Rep 2016;65. https://doi.org/10.15585/mmwr.mm6530e2

107. Kumar N, Brown JD. Access barriers to long-acting reversible contraceptives for adolescents. J Adolesc Health 2016;59:248-53. https://doi.org/10.1016/j.jadohealth.2016.03.039

108. Parks C, Peipert JF. Eliminating health disparities in unintended pregnancy with long-acting reversible contraception (LARC). Am J Obstet Gynecol 2016;214:681-8. https://doi.org/10.1016/j. ajog.2016.02.017

109. Klein DA, Berry-Bibee EN, Keglovitz Baker K, Malcolm NM, Rollison JM, Frederiksen BN. Providing quality family planning services to LGBTQIA individuals: a systematic review. Contraception 2018;97:378-91. https://doi.org/10.1016/j.contraception.2017.12.016 
FIGURE 1. Number, rate,* and ratio ${ }^{\dagger}$ of abortions performed, by year — selected reporting areas, $\$$ United States, $2006-2015$

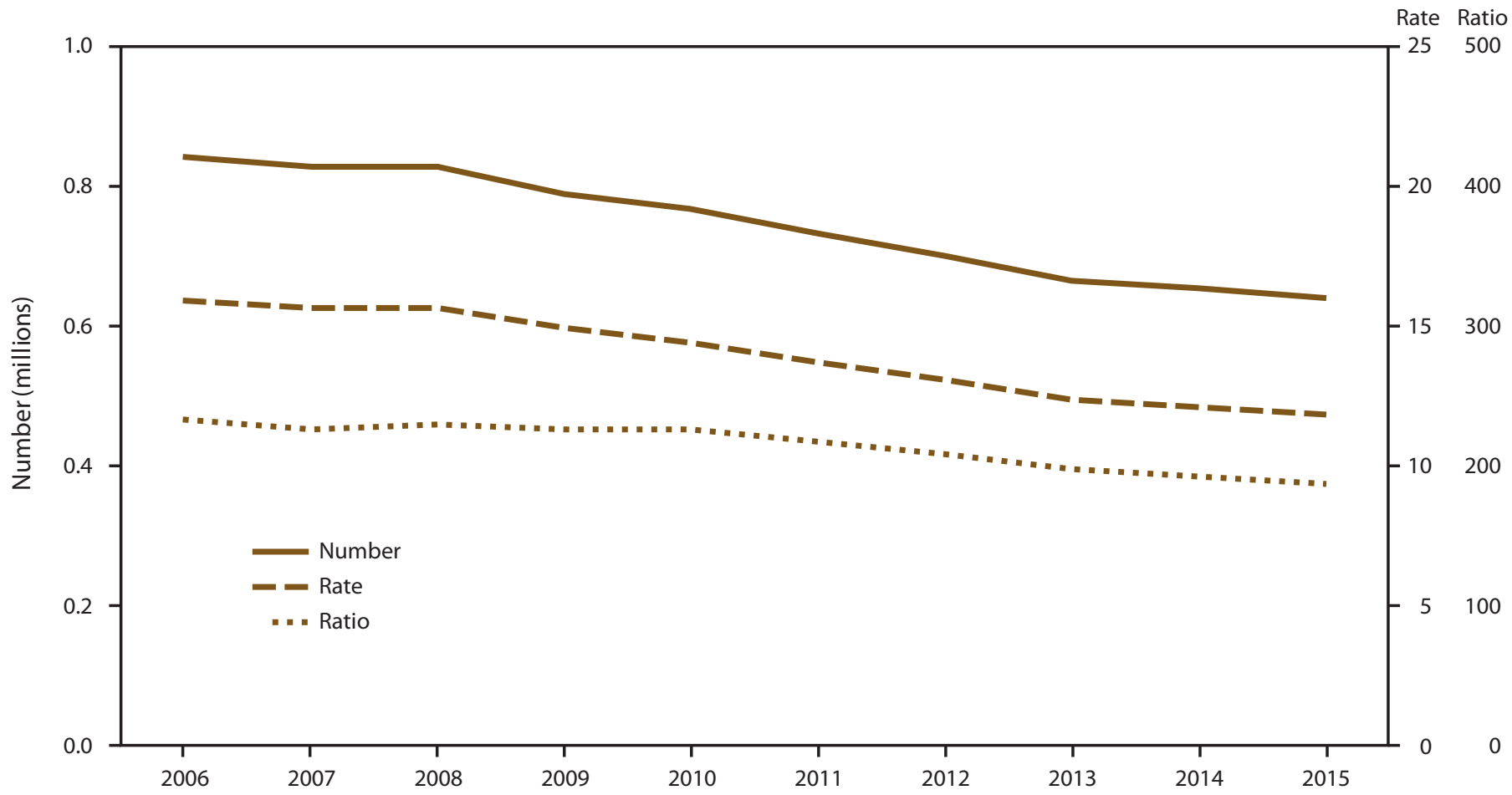

Year

* Number of abortions per 1,000 women aged 15-44 years.

+ Number of abortions per 1,000 live births.

$\S$ Data are for 49 reporting areas; excludes California, Maryland, and New Hampshire. 
FIGURE 2. Percentage of total abortions, abortion rate, ${ }^{*}$ and abortion ratio, ${ }^{\dagger}$ by age group of women who obtained a legal abortion - selected reporting areas, § United States, 2015

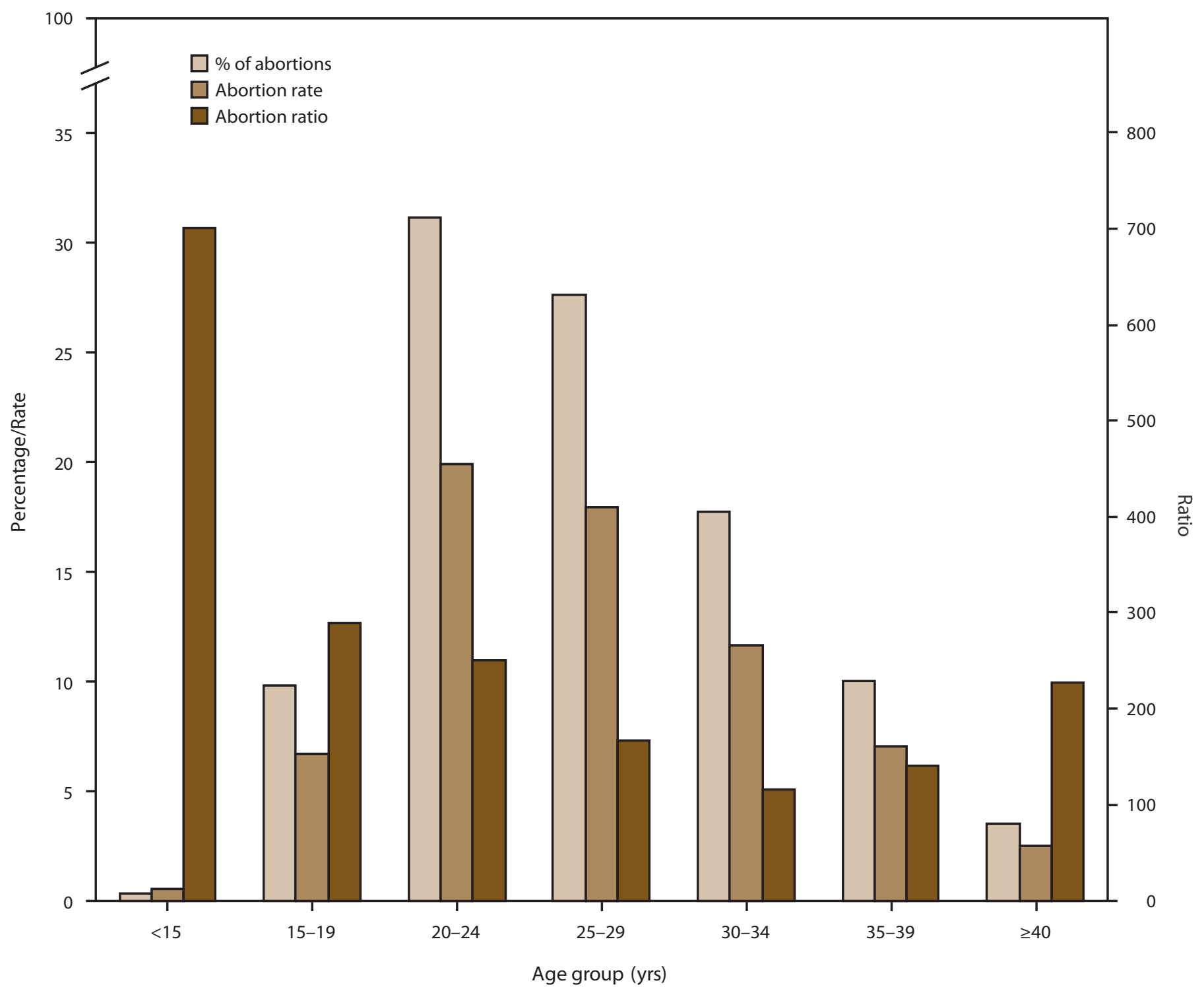

* Number of abortions per 1,000 women aged 15-44 years.

${ }^{\dagger}$ Number of abortions per 1,000 live births.

$\S$ Data are for 47 areas; excludes five areas (California, Florida, Maryland, New Hampshire, and Wyoming) that did not report, did not report by age, or did not meet reporting standards. 
FIGURE 3. Percentage* distribution of gestational ages at time of abortion, by age of woman — selected reporting areas, ${ }^{\dagger}$ United States, 2015

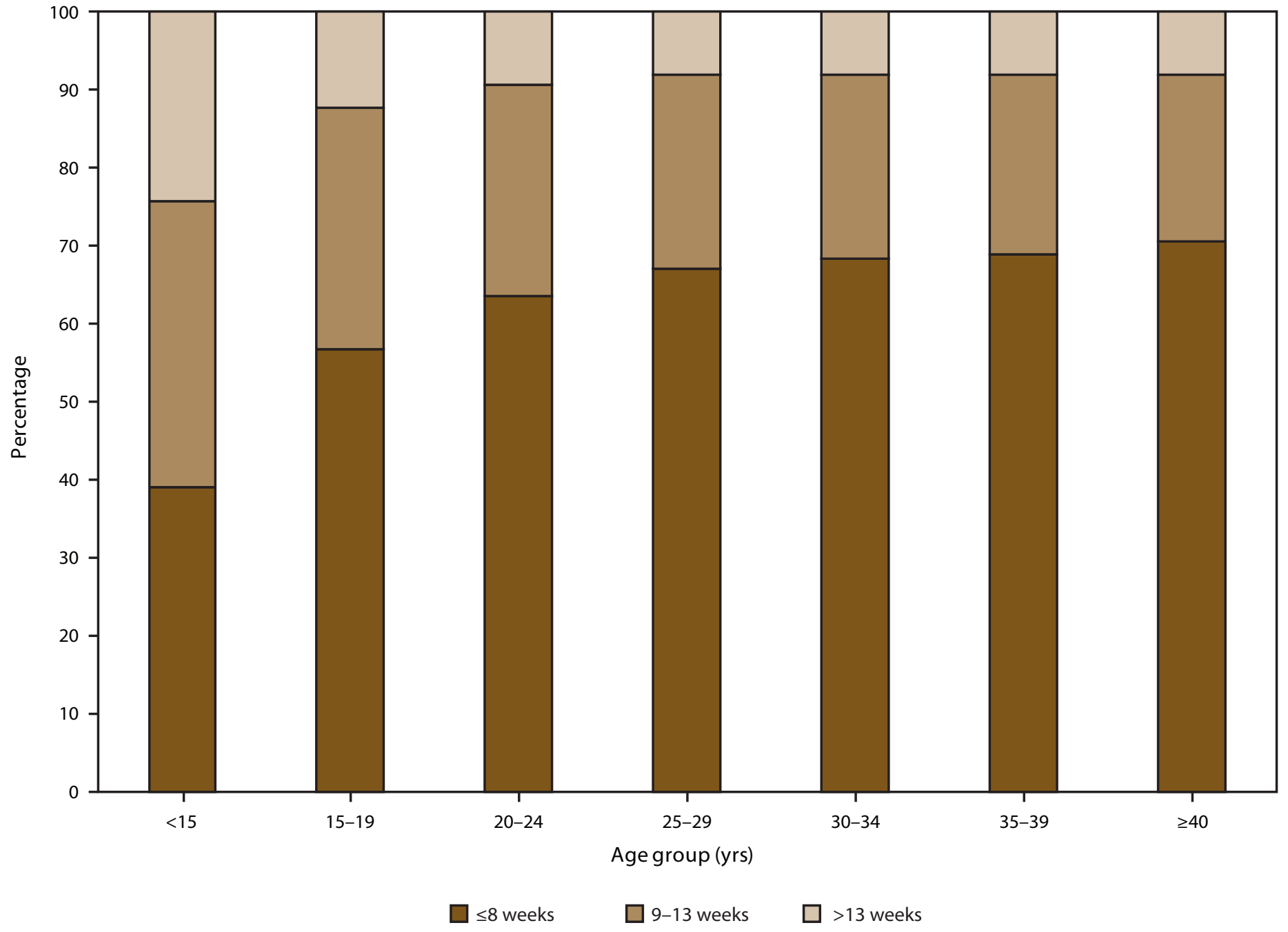

* Based on the total number of abortions reported with known weeks of gestation.

† Data from 39 reporting areas; excludes 13 reporting areas (California, Connecticut, District of Columbia, Florida, Illinois, Kentucky, Maryland, Massachusetts, New Hampshire, New York State, Pennsylvania, Wisconsin, and Wyoming) that did not report, did not report by weeks of gestation by age, or did not meet reporting standards. 
TABLE 1. Number, percentage, rate, ${ }^{*}$ and ratio $^{\dagger}$ of reported abortions - selected reporting areas, United States, 2006-2015

\begin{tabular}{|c|c|c|c|c|}
\hline \multirow[b]{2}{*}{ Year } & \multirow{2}{*}{$\frac{\begin{array}{c}\text { Selected } \\
\text { reporting areas }\end{array}}{\text { No. }}$} & \multicolumn{3}{|c|}{ Continuously reporting areas } \\
\hline & & No. $(\%)^{* *}$ & Rate & Ratio \\
\hline 2006 & $852,385^{\dagger \dagger}$ & $842,855(98.9)$ & 15.9 & 233 \\
\hline 2007 & 827,609 & $827,609(100.0)$ & 15.6 & 226 \\
\hline 2008 & 825,564 & $825,564(100.0)$ & 15.6 & 229 \\
\hline 2009 & $789,217 \S \S$ & $789,217(100.0)$ & 14.9 & 225 \\
\hline 2010 & 765,651 & $765,651(100.0)$ & 14.4 & 225 \\
\hline 2011 & 730,322 & $730,322(100.0)$ & 13.7 & 217 \\
\hline 2012 & 699,202 & $699,202(100.0)$ & 13.1 & 208 \\
\hline 2013 & 664,435 & $664,435(100.0)$ & 12.4 & 198 \\
\hline 2014 & 652,639 & $652,639(100.0)$ & 12.1 & 192 \\
\hline 2015 & 638,169 & $638,169(100.0)$ & 11.8 & 188 \\
\hline \multicolumn{5}{|c|}{$\begin{array}{l}\text { * Number of abortions per } 1,000 \text { women aged } 15-44 \text { years. } \\
{ }^{+} \text {Number of abortions per } 1,000 \text { live births. }\end{array}$} \\
\hline \multicolumn{5}{|c|}{$\begin{array}{l}\S \text { For each given year, excludes reporting areas that did not report that year's } \\
\text { abortion numbers to CDC: California (2006-2015), Maryland (2007-2015), } \\
\text { and New Hampshire (2006-2015). }\end{array}$} \\
\hline \multicolumn{5}{|c|}{$\begin{array}{l}\text { "For all years, excludes reporting areas that did not report abortion numbers } \\
\text { every year during the period of analysis (2006-2015): California, Maryland, } \\
\text { and New Hampshire. }\end{array}$} \\
\hline \multicolumn{5}{|c|}{$\begin{array}{l}\text { ** Abortions from areas that reported every year during } 2006-2015 \text { as a } \\
\text { percentage of all reported abortions. }\end{array}$} \\
\hline \multicolumn{5}{|c|}{$\begin{array}{l}\text { This number is greater than reported in the } 2006 \text { report because of numbers } \\
\text { subsequently provided by Louisiana. }\end{array}$} \\
\hline \multicolumn{5}{|c|}{$\begin{array}{l}\S \S \text { This number is greater than reported in the } 2009 \text { report because of numbers } \\
\text { subsequently provided by Delaware. }\end{array}$} \\
\hline
\end{tabular}


TABLE 2. Number, rate, ${ }^{*}$ and ratio ${ }^{\dagger}$ of reported abortions, by reporting area of residence and occurrence and by percentage of abortions obtained by out-of-state residents - United States, 2015

\begin{tabular}{|c|c|c|c|c|c|c|c|}
\hline \multirow[b]{2}{*}{ State/Area } & \multicolumn{3}{|c|}{ Residence } & \multicolumn{3}{|c|}{ Occurrence } & \multirow{2}{*}{$\begin{array}{c}\% \text { obtained by out-of- } \\
\text { state residents }^{\S}\end{array}$} \\
\hline & No. & Rate & Ratio & No. & Rate & Ratio & \\
\hline Alabama & 6,618 & 6.9 & 111 & 5,899 & 6.2 & 99 & 13.1 \\
\hline Alaska & 1,459 & 10.0 & 129 & 1,334 & 9.1 & 118 & 0.5 \\
\hline Arizona & 12,644 & 9.6 & 148 & 12,655 & 9.6 & 148 & 1.4 \\
\hline Arkansas & 3,805 & 6.6 & 98 & 3,771 & 6.5 & 97 & 18.6 \\
\hline Californiaף & - & - & - & - & - & - & - \\
\hline Colorado & 8,975 & 8.1 & 135 & 10,114 & 9.1 & 152 & 11.3 \\
\hline Connecticut & 9,888 & 14.5 & 277 & 9,938 & 14.6 & 278 & 2.7 \\
\hline Delaware & 2,889 & 16.0 & 259 & 2,785 & 15.4 & 249 & 15.0 \\
\hline District of Columbia** & 1,424 & 7.9 & 149 & 1,267 & 7.0 & 132 & - \\
\hline Florida $^{\dagger \dagger}$ & - & - & - & 72,023 & 19.3 & 321 & - \\
\hline Georgia & 26,835 & 12.7 & 204 & 31,009 & 14.6 & 236 & 14.5 \\
\hline Hawaii & 2,042 & 7.6 & 111 & 2,026 & 7.6 & 110 & 0.3 \\
\hline Idaho & 1,695 & 5.3 & 74 & 1,272 & 4.0 & 56 & 4.6 \\
\hline Illinois & 35,237 & 13.7 & 223 & 39,856 & 15.5 & 252 & 8.5 \\
\hline Indiana & 9,546 & 7.4 & 114 & 7,957 & 6.1 & 95 & 5.9 \\
\hline lowa ${ }^{\S \S}$ & 3,676 & 6.2 & 93 & 3,989 & 6.8 & 101 & 16.3 \\
\hline Kansas & 3,637 & 6.5 & 93 & 6,931 & 12.4 & 177 & 49.0 \\
\hline Kentucky & 4,585 & 5.4 & 82 & 3,188 & 3.7 & 57 & 12.8 \\
\hline Louisiana & 8,515 & 9.0 & 132 & 9,362 & 9.9 & 145 & 14.6 \\
\hline Maine & 1,743 & 7.5 & 138 & 1,836 & 7.9 & 146 & 3.1 \\
\hline Maryland" & - & - & - & - & - & - & - \\
\hline Massachusetts $§ \S$ & 17,959 & 13.1 & 251 & 18,570 & 13.5 & 260 & 3.8 \\
\hline Michigan & 26,283 & 14.0 & 232 & 27,151 & 14.4 & 240 & 4.2 \\
\hline Minnesota & 9,234 & 8.8 & 132 & 9,861 & 9.4 & 141 & 9.8 \\
\hline Mississippi & 4,699 & 7.8 & 122 & 2,613 & 4.4 & 68 & 5.1 \\
\hline Missouri & 8,636 & 7.3 & 115 & 4,765 & 4.0 & 63 & 9.5 \\
\hline Montana & 1,433 & 7.7 & 114 & 1,611 & 8.6 & 128 & 13.3 \\
\hline Nebraska & 1,893 & 5.2 & 71 & 2,004 & 5.5 & 75 & 11.4 \\
\hline Nevada & 6,760 & 11.8 & 186 & 7,116 & 12.4 & 196 & 5.5 \\
\hline New Hampshireף & - & - & - & - & - & - & - \\
\hline New Jersey & 23,224 & 13.5 & 225 & 22,991 & 13.4 & 223 & 5.5 \\
\hline New Mexico $\$ \S$ & 3,496 & 8.8 & 135 & 4,669 & 11.8 & 181 & 27.2 \\
\hline New York & 88,762 & 22.0 & 374 & 93,096 & 23.1 & 392 & 5.1 \\
\hline New York City & NA & NA & NA & 63,646 & 32.8 & 544 & NA \\
\hline New York State & NA & NA & NA & 29,450 & 14.1 & 245 & NA \\
\hline
\end{tabular}

See table footnotes on the next page. 
TABLE 2. (Continued) Number, rate, ${ }^{*}$ and ratio ${ }^{\dagger}$ of reported abortions, by reporting area of residence and occurrence and by percentage of abortions obtained by out-of-state residents - United States, 2015

\begin{tabular}{|c|c|c|c|c|c|c|c|}
\hline \multirow[b]{2}{*}{ State/Area } & \multicolumn{3}{|c|}{ Residence } & \multicolumn{3}{|c|}{ Occurrence } & \multirow{2}{*}{$\begin{array}{l}\% \text { obtained by } \\
\text { out-of-state residents } \\
\S\end{array}$} \\
\hline & No. & Rate & Ratio & No. & Rate & Ratio & \\
\hline North Carolina & 23,066 & 11.6 & 191 & 27,631 & 13.9 & 229 & 17.5 \\
\hline North Dakota & 976 & 6.6 & 86 & 1,166 & 7.9 & 103 & 29.6 \\
\hline Ohio & 21,215 & 9.6 & 152 & 20,976 & 9.5 & 151 & 5.8 \\
\hline Oklahoma & 4,813 & 6.3 & 91 & 4,709 & 6.1 & 89 & 8.0 \\
\hline Oregon & 7,847 & 10.0 & 172 & 8,610 & 10.9 & 189 & 11.2 \\
\hline Pennsylvania & 32,025 & 13.3 & 227 & 31,818 & 13.3 & 226 & 5.0 \\
\hline Rhode Island & 2,348 & 11.2 & 214 & 2,649 & 12.6 & 241 & 14.7 \\
\hline South Carolina & 11,032 & 11.6 & 190 & 5,778 & 6.1 & 99 & 5.9 \\
\hline South Dakota & 659 & 4.2 & 53 & 444 & 2.8 & 36 & 13.3 \\
\hline Tennessee & 10,361 & 8.0 & 127 & 11,411 & 8.8 & 140 & 20.3 \\
\hline Texas & 54,194 & 9.4 & 134 & 53,940 & 9.4 & 134 & 1.8 \\
\hline Utah & 3,123 & 4.8 & 62 & 3,176 & 4.9 & 63 & 6.0 \\
\hline Vermont & 1,121 & 9.7 & 190 & 1,265 & 10.9 & 214 & 12.4 \\
\hline Virginia & 18,501 & 11.0 & 179 & 18,663 & 11.1 & 181 & 5.2 \\
\hline Washington & 17,230 & 12.2 & 194 & 17,098 & 12.1 & 192 & 4.5 \\
\hline West Virginia & 1,736 & 5.2 & 88 & 1,516 & 4.5 & 77 & 12.7 \\
\hline Wisconsin & 6,731 & 6.2 & 100 & 5,660 & 5.2 & 84 & 3.5 \\
\hline Wyoming & 599 & 5.4 & 77 & —*** & $-^{++t}$ & - $^{++\dagger}$ & —†+ \\
\hline Canada & 83 & NA & NA & NA & NA & NA & NA \\
\hline Mexico & 256 & NA & NA & NA & NA & NA & NA \\
\hline Other country or territory & 237 & NA & NA & NA & NA & NA & NA \\
\hline Total known & 557,304 & NA & NA & NA & NA & NA & NA \\
\hline Percentage reported by known residence & 87.3 & NA & NA & NA & NA & NA & NA \\
\hline Total unknown residence & 80,865 & NA & NA & NA & NA & NA & NA \\
\hline Out of state, exact residence not stated & 5,340 & NA & NA & NA & NA & NA & NA \\
\hline No information on residence provided & 75,525 & NA & NA & NA & NA & NA & NA \\
\hline Percentage reported by unknown residence & 12.7 & NA & NA & NA & NA & NA & NA \\
\hline Total & 638,169 & NA & NA & NA & NA & NA & NA \\
\hline
\end{tabular}

Abbreviation: $\mathrm{NA}=$ not applicable.

* Number of abortions per 1,000 women aged 15-44 years.

+ Number of abortions per 1,000 live births.

$\S$ Additional details on the state in which abortions were provided, cross-tabulated by the state of maternal residence, are at http://www.cdc.gov/reproductivehealth/ data_stats/Abortion.htm.

" Reporting area did not report; because numbers for this area are available only from other reporting areas where residents obtained abortions, meaningful statistics cannot be reported.

** Because reporting is not mandatory, a complete count of the number of abortions performed in the District of Columbia could not be obtained and were only reported for area residents.

${ }^{+\dagger}$ Reported by occurrence only; because abortion numbers by residence for Florida are available only from other states where residents obtained abortions, meaningful statistics cannot be reported.

$\S \S$ Reporting area reported abortion numbers for both in-state and out-of-state residents; for out-of-state residents, the state or area of residence was not provided.

ๆๆ Data from hospitals and licensed ambulatory care facilities only; because reporting is not mandatory for private physicians and women's centers, a complete count of the number of abortions performed in New Jersey could not be obtained.

*** Total abortion number $<20$.

${ }^{++\dagger}$ Abortion rates and ratios and percentage of abortions obtained by out-of-state residents were not calculated for Wyoming because results based on a small number of abortions are unstable. 
TABLE 3. Reported abortions, by known age group and reporting area of occurrence - selected reporting areas,* United States, 2015

\begin{tabular}{|c|c|c|c|c|c|c|c|c|}
\hline \multirow[b]{3}{*}{ State/Area } & \multicolumn{7}{|c|}{ Age group (yrs) } & \multirow{3}{*}{$\begin{array}{c}\text { Total abortions reportec } \\
\text { by known age }\end{array}$} \\
\hline & $<15$ & $15-19$ & $20-24$ & $25-29$ & $30-34$ & $35-39$ & $\geq 40$ & \\
\hline & No. $(\%)^{\dagger}$ & No. (\%) & No. (\%) & No. (\%) & No. (\%) & No. (\%) & No. (\%) & \\
\hline Alabama & $23(0.4)$ & $643(10.9)$ & $2,085(35.3)$ & $1,582(26.8)$ & $953(16.2)$ & $478(8.1)$ & $135(2.3)$ & $5,899(100.0)$ \\
\hline Alaska & - & $152(11.4)$ & 445 (33.4) & $361(27.1)$ & $206(15.4)$ & $121(9.1)$ & - & $1,334(100.0)$ \\
\hline Arizona & $25(0.2)$ & $1,177(9.3)$ & $3,948(31.2)$ & $3,416(27.0)$ & $2,228(17.6)$ & $1,344(10.6)$ & $513(4.1)$ & $12,651(100.0)$ \\
\hline Arkansas & $16(0.4)$ & 391 (10.4) & $1,214(32.2)$ & 997 (26.4) & $693(18.4)$ & $344(9.1)$ & $116(3.1)$ & $3,771(100.0)$ \\
\hline Colorado & $27(0.3)$ & $1,019(10.1)$ & $3,196(31.8)$ & 2,735 (27.2) & $1,712(17.0)$ & 993 (9.9) & 372 (3.7) & $10,054(99.4)$ \\
\hline Connecticut & $21(0.2)$ & $992(10.2)$ & $2,931(30.1)$ & $2,735(28.1)$ & $1,768(18.2)$ & 960 (9.9) & 321 (3.3) & $9,728(97.9)$ \\
\hline Delaware & $5(0.2)$ & $328(11.8)$ & $892(32.0)$ & 747 (26.8) & 466 (16.7) & $264(9.5)$ & $83(3.0)$ & $2,785(100.0)$ \\
\hline $\begin{array}{l}\text { District of } \\
\text { Columbia** }\end{array}$ & - & $113(8.9)$ & $406(32.0)$ & $390(30.8)$ & 227 (17.9) & 99 (7.8) & - & $1,267(100.0)$ \\
\hline Georgia & $86(0.3)$ & $2,783(9.0)$ & $9,638(31.1)$ & $8,650(27.9)$ & $5,558(17.9)$ & $3,178(10.2)$ & $1,116(3.6)$ & $31,009(100.0)$ \\
\hline Hawaii & $5(0.2)$ & $215(10.7)$ & $580(28.8)$ & $529(26.3)$ & $356(17.7)$ & 235 (11.7) & $94(4.7)$ & $2,014(99.4)$ \\
\hline Idaho & - & 165 (13.0) & $433(34.0)$ & $274(21.5)$ & $202(15.9)$ & $144(11.3)$ & - & $1,272(100.0)$ \\
\hline Illinois ${ }^{\dagger \dagger}$ & $82(0.2)$ & $3,415(9.9)$ & $10,794(31.4)$ & $9,658(28.1)$ & $5,928(17.2)$ & $3,403(9.9)$ & $1,113(3.2)$ & $34,393(99.7)$ \\
\hline Indiana & $25(0.3)$ & $821(10.3)$ & $2,686(33.8)$ & $2,111(26.5)$ & $1,279(16.1)$ & $780(9.8)$ & $255(3.2)$ & $7,957(100.0)$ \\
\hline lowa & $13(0.3)$ & 445 (11.2) & $1,316(33.0)$ & $1,028(25.8)$ & $700(17.6)$ & $360(9.0)$ & $120(3.0)$ & $3,982(99.8)$ \\
\hline Kansas & $13(0.2)$ & $657(9.5)$ & $2,190(31.6)$ & $1,829(26.4)$ & $1,281(18.5)$ & 735 (10.6) & 226 (3.3) & $6,931(100.0)$ \\
\hline Kentucky & $16(0.5)$ & $337(10.6)$ & $1,037(32.5)$ & $851(26.7)$ & $521(16.3)$ & $288(9.0)$ & $138(4.3)$ & $3,188(100.0)$ \\
\hline Louisiana & $37(0.4)$ & $828(8.8)$ & $2,928(31.3)$ & $2,758(29.5)$ & $1,662(17.8)$ & $884(9.4)$ & $264(2.8)$ & $9,361(100.0)$ \\
\hline Maine & $5(0.3)$ & $206(11.2)$ & $582(31.7)$ & $478(26.0)$ & 292 (15.9) & $206(11.2)$ & 66 (3.6) & $1,835(99.9)$ \\
\hline Massachusetts & $27(0.1)$ & $1,547(8.3)$ & $5,492(29.6)$ & $5,342(28.8)$ & $3,416(18.4)$ & $1,964(10.6)$ & $777(4.2)$ & $18,565(100.0)$ \\
\hline Michigan & $84(0.3)$ & $2,579(9.5)$ & $8,970(33.1)$ & $7,610(28.1)$ & $4,388(16.2)$ & $2,595(9.6)$ & $848(3.1)$ & $27,074(99.7)$ \\
\hline Minnesota & $18(0.2)$ & $854(8.7)$ & $2,939(29.8)$ & $2,690(27.3)$ & $1,912(19.4)$ & $1,107(11.2)$ & 341 (3.5) & $9,861(100.0)$ \\
\hline Mississippi & $13(0.5)$ & $258(9.9)$ & $875(33.5)$ & $748(28.6)$ & $450(17.2)$ & $210(8.0)$ & $59(2.3)$ & $2,613(100.0)$ \\
\hline Missouri & $14(0.3)$ & $480(10.1)$ & $1,647(34.6)$ & $1,278(26.8)$ & 779 (16.4) & $413(8.7)$ & $153(3.2)$ & $4,764(100.0)$ \\
\hline Montana & - & $201(12.5)$ & $515(32.0)$ & $419(26.0)$ & 269 (16.7) & $145(9.0)$ & - & $1,610(99.9)$ \\
\hline Nebraska & $7(0.3)$ & $194(9.7)$ & $576(28.7)$ & $578(28.8)$ & $360(18.0)$ & $223(11.1)$ & $66(3.3)$ & $2,004(100.0)$ \\
\hline Nevada & $12(0.2)$ & $636(9.2)$ & $1,974(28.6)$ & $1,906(27.6)$ & $1,350(19.6)$ & $713(10.3)$ & $313(4.5)$ & $6,904(97.0)$ \\
\hline New Jersey ${ }^{\S}$ & $53(0.2)$ & $2,234(9.7)$ & $6,649(28.9)$ & $6,569(28.6)$ & $4,124(18.0)$ & $2,411(10.5)$ & $931(4.1)$ & $22,971(99.9)$ \\
\hline New Mexico & $24(0.5)$ & 614 (13.7) & $1,425(31.9)$ & $1,112(24.9)$ & $763(17.1)$ & $370(8.3)$ & 158 (3.5) & $4,466(95.7)$ \\
\hline New York & $241(0.3)$ & $9,303(10.0)$ & $27,481(29.6)$ & $25,365(27.3)$ & $17,110(18.4)$ & $9,785(10.5)$ & $3,685(4.0)$ & $92,970(99.9)$ \\
\hline New York City & $153(0.2)$ & $5,796(9.1)$ & $18,148(28.5)$ & $17,626(27.7)$ & $12,045(18.9)$ & $7,156(11.2)$ & $2,720(4.3)$ & $63,644(100.0)$ \\
\hline New York State & $88(0.3)$ & $3,507(12.0)$ & $9,333(31.8)$ & $7,739(26.4)$ & $5,065(17.3)$ & $2,629(9.0)$ & 965 (3.3) & $29,326(99.6)$ \\
\hline
\end{tabular}

See table footnotes on the next page. 
TABLE 3. (Continued) Reported abortions, by known age group and reporting area of occurrence — selected reporting areas,* United States, 2015

\begin{tabular}{|c|c|c|c|c|c|c|c|c|}
\hline \multirow[b]{3}{*}{ State/Area } & \multicolumn{7}{|c|}{ Age group (yrs) } & \multirow{3}{*}{$\begin{array}{c}\text { Total abortions reported } \\
\text { by known age }\end{array}$} \\
\hline & $<15$ & $15-19$ & $20-24$ & $25-29$ & $30-34$ & $35-39$ & $\geq 40$ & \\
\hline & No. $(\%)^{\dagger}$ & No. (\%) & No. (\%) & No. (\%) & No. (\%) & No. (\%) & No. (\%) & \\
\hline North Carolina & $70(0.3)$ & $2,486(9.5)$ & $8,388(32.1)$ & $7,277(27.8)$ & $4,451(17.0)$ & $2,567(9.8)$ & $892(3.4)$ & $26,131(94.6)$ \\
\hline North Dakota & $6(0.5)$ & $107(9.2)$ & 395 (33.9) & $290(24.9)$ & $211(18.1)$ & $121(10.4)$ & $36(3.1)$ & $1,166(100.0)$ \\
\hline Ohio & $73(0.3)$ & $2,114(10.1)$ & $6,809(32.5)$ & $5,975(28.5)$ & 3,441 (16.4) & $1,909(9.1)$ & $655(3.1)$ & $20,976(100.0)$ \\
\hline Oklahoma & $10(0.2)$ & $515(10.9)$ & $1,554(33.0)$ & $1,215(25.8)$ & 837 (17.8) & $423(9.0)$ & $154(3.3)$ & $4,708(100.0)$ \\
\hline Oregon & $21(0.2)$ & $901(10.5)$ & $2,622(30.5)$ & 2,297 (26.7) & 1,551 (18.0) & $871(10.1)$ & $344(4.0)$ & $8,607(100.0)$ \\
\hline Pennsylvania & $86(0.3)$ & $3,028(9.5)$ & $10,339(32.5)$ & $9,119(28.7)$ & $5,303(16.7)$ & $2,951(9.3)$ & $992(3.1)$ & $31,818(100.0)$ \\
\hline Rhode Island & $8(0.3)$ & $241(9.1)$ & 837 (31.7) & 727 (27.5) & 434 (16.4) & $279(10.6)$ & $114(4.3)$ & $2,640(99.7)$ \\
\hline South Carolina & $12(0.2)$ & $602(10.4)$ & $1,884(32.6)$ & $1,566(27.1)$ & $962(16.6)$ & $550(9.5)$ & $202(3.5)$ & $5,778(100.0)$ \\
\hline South Dakota & - & $41(9.2)$ & $145(32.7)$ & $112(25.2)$ & $85(19.1)$ & $46(10.4)$ & - & $444(100.0)$ \\
\hline Tennessee & $34(0.3)$ & $1,075(9.5)$ & $3,627(32.2)$ & $3,159(28.0)$ & 1,988 (17.6) & $1,049(9.3)$ & $334(3.0)$ & $11,266(98.7)$ \\
\hline Texas & $151(0.3)$ & $5,001(9.3)$ & $16,738(31.0)$ & $15,016(27.8)$ & 9,592 (17.8) & $5,490(10.2)$ & $1,946(3.6)$ & $53,934(100.0)$ \\
\hline Utah & $0(0.0)$ & 363 (11.5) & $1,012(32.1)$ & $808(25.6)$ & $520(16.5)$ & $320(10.1)$ & $131(4.2)$ & 3,154 (99.3) \\
\hline Vermont & - & $127(10.2)$ & $383(30.8)$ & 335 (27.0) & $240(19.3)$ & $116(9.3)$ & - & $1,243(98.3)$ \\
\hline Virginia & $38(0.2)$ & $1,558(8.4)$ & $5,686(30.6)$ & $5,086(27.4)$ & $3,554(19.1)$ & $1,979(10.7)$ & 677 (3.6) & $18,578(99.5)$ \\
\hline Washington & $36(0.2)$ & $1,905(11.1)$ & $5,061(29.6)$ & 4,469 (26.1) & 3,117 (18.2) & 1,813 (10.6) & $692(4.0)$ & $17,093(100.0)$ \\
\hline West Virginia & $6(0.4)$ & $145(9.6)$ & 478 (31.6) & 394 (26.1) & 304 (20.1) & 145 (9.6) & $40(2.6)$ & 1,512 (99.7) \\
\hline Wisconsint† & $13(0.2)$ & $623(11.4)$ & $1,813(33.2)$ & $1,403(25.7)$ & 955 (17.5) & $482(8.8)$ & $172(3.1)$ & $5,461(100.0)$ \\
\hline Total & $1,471(0.3)$ & $54,419(9.8)$ & $173,615(31.1)$ & $153,994(27.6)$ & $98,498(17.7)$ & $55,863(10.0)$ & $19,882(3.5)$ & $557,742(99.5)^{\text {ศๆ }}$ \\
\hline Abortion rate $\mathrm{e}^{* * *}$ & 0.5 & 6.7 & 19.9 & 17.9 & 11.6 & 7.0 & 2.5 & 11.2 \\
\hline Abortion ratio ${ }^{+\dagger \dagger}$ & 701 & 289 & 250 & 167 & 115 & 140 & 227 & 177 \\
\hline
\end{tabular}

* Data from 47 reporting areas; excludes five reporting areas (California, Florida, Maryland, New Hampshire, and Wyoming) that did not report, did not report by age, or did not meet reporting standards.

† Percentages for the individual component categories might not add to 100 because of rounding.

$\S$ Percentage is calculated as the number of abortions reported by known age divided by the sum of abortions reported by known and unknown age.

" Cells with a value in the range of 1-4 or cells that would allow for calculation of these small values have been suppressed.

** Because reporting is not mandatory, information could not be obtained for all abortions performed in the District of Columbia.

${ }^{+\dagger}$ Includes residents only.

$\S \S$ Data from hospitals and licensed ambulatory care facilities only; because reporting is not mandatory for private physicians and women's centers, information could not be obtained for all abortions performed in New Jersey.

กศ Percentage based on a total of 560,589 abortions reported among the areas that met reporting standards for age.

*** Number of abortions obtained by women in a given age group per 1,000 women in that same age group. Women aged 13-14 years were used as the denominator for the group of women aged $<15$ years, and women aged 40-44 years were used as the denominator for the group of women aged $\geq 40$ years. Women aged 15-44 years were used as the denominator for the overall rate. For each reporting area, abortions for women of unknown age were distributed according to the distribution of abortions among women of known age for that area.

${ }^{++\dagger}$ Number of abortions obtained by women in a given age group per 1,000 live births to women in that same age group. For each reporting area, abortions for women of unknown age were distributed according to the distribution of abortions among women of known age for that area. 
TABLE 4. Reported abortions, by known age group and year — selected reporting areas, * United States, 2006-2015

\begin{tabular}{|c|c|c|c|c|c|c|c|c|c|c|c|c|c|c|}
\hline \multirow[b]{2}{*}{ Age group (yrs) } & \multicolumn{10}{|c|}{ Year } & \multicolumn{4}{|c|}{$\%$ change } \\
\hline & 2006 & 2007 & 2008 & 2009 & 2010 & 2011 & 2012 & 2013 & 2014 & 2015 & $\begin{array}{c}2006 \text { to } \\
2010\end{array}$ & $\begin{array}{c}2011 \text { to } \\
2015\end{array}$ & $\begin{array}{l}2014 \text { to } \\
2015\end{array}$ & $\begin{array}{l}2006 \text { to } \\
2015\end{array}$ \\
\hline \multicolumn{15}{|l|}{$\%$ of abortions } \\
\hline$<15$ & 0.5 & 0.5 & 0.5 & 0.5 & 0.5 & 0.4 & 0.4 & 0.3 & 0.3 & 0.3 & 0.0 & -25.0 & 0.0 & -40.0 \\
\hline 15-19 & 16.5 & 16.5 & 16.1 & 15.5 & 14.6 & 13.5 & 12.2 & 11.4 & 10.4 & 9.8 & -11.5 & -27.4 & -5.8 & -40.6 \\
\hline $20-24$ & 32.7 & 32.7 & 32.7 & 32.7 & 32.9 & 32.9 & 32.8 & 32.7 & 32.1 & 31.1 & 0.6 & -5.5 & -3.1 & -4.9 \\
\hline $25-29$ & 24.1 & 24.2 & 24.4 & 24.4 & 24.5 & 24.9 & 25.4 & 25.9 & 26.8 & 27.6 & 1.7 & 10.8 & 3.0 & 14.5 \\
\hline $30-34$ & 14.2 & 14.1 & 14.3 & 14.8 & 15.3 & 15.8 & 16.4 & 16.8 & 17.2 & 17.7 & 7.7 & 12.0 & 2.9 & 24.6 \\
\hline $35-39$ & 8.8 & 8.8 & 8.8 & 8.8 & 8.9 & 8.9 & 9.1 & 9.2 & 9.7 & 10.0 & 1.1 & 12.4 & 3.1 & 13.6 \\
\hline$\geq 40$ & 3.1 & 3.2 & 3.1 & 3.3 & 3.4 & 3.6 & 3.7 & 3.6 & 3.6 & 3.6 & 9.7 & 0.0 & 0.0 & 16.1 \\
\hline \multicolumn{15}{|l|}{ Abortion rate $^{\dagger}$} \\
\hline$<15$ & 1.2 & 1.2 & 1.2 & 1.1 & 1.0 & 0.9 & 0.8 & 0.6 & 0.5 & 0.5 & -16.7 & -44.4 & 0.0 & -58.3 \\
\hline $15-19$ & 14.5 & 14.1 & 13.8 & 12.8 & 11.7 & 10.5 & 9.2 & 8.2 & 7.3 & 6.7 & -19.3 & -36.2 & -8.2 & -53.8 \\
\hline $20-24$ & 29.7 & 29.2 & 29.3 & 27.7 & 26.8 & 25.0 & 23.3 & 21.9 & 20.9 & 19.9 & -9.8 & -20.4 & -4.8 & -33.0 \\
\hline $25-29$ & 22.5 & 21.8 & 21.8 & 20.7 & 20.2 & 19.4 & 18.9 & 18.2 & 18.1 & 17.9 & -10.2 & -7.7 & -1.1 & -20.4 \\
\hline $30-34$ & 13.8 & 13.6 & 13.8 & 13.4 & 13.2 & 12.7 & 12.4 & 11.8 & 11.7 & 11.7 & -4.3 & -7.9 & 0.0 & -15.2 \\
\hline $35-39$ & 7.9 & 7.8 & 7.8 & 7.6 & 7.6 & 7.5 & 7.3 & 7.0 & 7.1 & 7.0 & -3.8 & -6.7 & -1.4 & -11.4 \\
\hline$\geq 40$ & 2.6 & 2.6 & 2.7 & 2.8 & 2.8 & 2.8 & 2.8 & 2.5 & 2.5 & 2.5 & 7.7 & -10.7 & 0.0 & -3.8 \\
\hline \multicolumn{15}{|l|}{ Abortion ratio } \\
\hline$<15$ & 747 & 770 & 804 & 832 & 848 & 839 & 804 & 791 & 745 & 700 & 13.5 & -16.6 & -6.0 & -6.3 \\
\hline 15-19 & 349 & 336 & 337 & 328 & 332 & 325 & 304 & 299 & 291 & 289 & -4.9 & -11.1 & -0.7 & -17.2 \\
\hline $20-24$ & 278 & 274 & 283 & 281 & 290 & 284 & 272 & 262 & 256 & 250 & 4.3 & -12.0 & -2.3 & -10.1 \\
\hline $25-29$ & 189 & 183 & 186 & 183 & 184 & 178 & 174 & 168 & 166 & 167 & -2.6 & -6.2 & 0.6 & -11.6 \\
\hline $30-34$ & 142 & 137 & 140 & 138 & 138 & 132 & 128 & 121 & 116 & 115 & -2.8 & -12.9 & -0.9 & -19.0 \\
\hline $35-39$ & 173 & 170 & 174 & 172 & 171 & 165 & 158 & 147 & 145 & 140 & -1.2 & -15.2 & -3.4 & -19.1 \\
\hline$\geq 40$ & 283 & 278 & 271 & 275 & 273 & 275 & 269 & 245 & 239 & 228 & -3.5 & -17.1 & -4.6 & -19.4 \\
\hline Total (no.) & 732,654 & 722,831 & 726,839 & 695,952 & 675,732 & 643,628 & 614,570 & 582,260 & 569,100 & 556,221 & - & - & - & - \\
\hline
\end{tabular}

* Data from 44 reporting areas; by year, these reporting areas represent $98 \%-99 \%$ of all abortions reported to CDC by age during 2006-2015. Excludes eight reporting areas (California, District of Columbia, Florida, Maine, Maryland, New Hampshire, Vermont, and Wyoming) that did not report, did not report by age, or did not meet reporting standards for $\geq 1$ year.

${ }^{\dagger}$ Number of abortions obtained by women in a given age group per 1,000 women in that same age group. Women aged 13-14 years were used as the denominator for the group of women aged $<15$ years, and women aged 40-44 years were used as the denominator for the group of women aged $\geq 40$ years. Women aged 15-44 years were used as the denominator for the overall rate. For each reporting area, abortions for women of unknown age were distributed according to the distribution of abortions among women of known age for that area.

$\S$ Number of abortions obtained by women in a given age group per 1,000 live births to women in that same age group. For each reporting area, abortions for women of unknown age were distributed according to the distribution of abortions among women of known age for that area. 
TABLE 5. Reported abortions among adolescents, by known age and reporting area of occurrence - selected reporting areas, ${ }^{*}$ United States, 2015

\begin{tabular}{|c|c|c|c|c|c|c|c|}
\hline \multirow[b]{3}{*}{ State/Area } & \multicolumn{6}{|c|}{ Age (yrs) } & \multirow[b]{3}{*}{ Total no. } \\
\hline & $<15$ & 15 & 16 & 17 & 18 & 19 & \\
\hline & No. $(\%)^{\dagger}$ & No. (\%) & No. (\%) & No. (\%) & No. (\%) & No. (\%) & \\
\hline Alabama & $23(3.5)$ & $42(6.3)$ & $55(8.3)$ & $85(12.8)$ & $178(26.7)$ & $283(42.5)$ & 666 \\
\hline Alaska & — & - & $13(8.3)$ & $19(12.2)$ & $47(30.1)$ & $63(40.4)$ & 156 \\
\hline Arizona & $25(2.1)$ & $50(4.2)$ & $85(7.1)$ & $153(12.7)$ & $358(29.8)$ & $531(44.2)$ & 1,202 \\
\hline Arkansas & $16(3.9)$ & $28(6.9)$ & $40(9.8)$ & $57(14.0)$ & $113(27.8)$ & $153(37.6)$ & 407 \\
\hline Colorado & $27(2.6)$ & $53(5.1)$ & $120(11.5)$ & $141(13.5)$ & $281(26.9)$ & $424(40.5)$ & 1,046 \\
\hline Connecticut & $21(2.1)$ & $40(3.9)$ & $94(9.3)$ & $205(20.2)$ & $262(25.9)$ & 391 (38.6) & 1,013 \\
\hline Delaware & $5(1.5)$ & $23(6.9)$ & $26(7.8)$ & $67(20.1)$ & $96(28.8)$ & $116(34.8)$ & 333 \\
\hline District of Columbia ${ }^{\mathfrak{n}, * *}$ & - & - & $10(8.6)$ & $23(19.8)$ & $29(25.0)$ & $46(39.7)$ & 116 \\
\hline Georgia & $86(3.0)$ & $174(6.1)$ & $284(9.9)$ & $411(14.3)$ & $782(27.3)$ & $1,132(39.5)$ & 2,869 \\
\hline Hawaii & $5(2.3)$ & $14(6.4)$ & 24 (10.9) & $36(16.4)$ & $58(26.4)$ & $83(37.7)$ & 220 \\
\hline Idaho & - & - & $15(9.0)$ & $28(16.8)$ & $46(27.5)$ & $71(42.5)$ & 167 \\
\hline Indiana & $25(3.0)$ & $43(5.1)$ & $62(7.3)$ & $114(13.5)$ & $260(30.7)$ & $342(40.4)$ & 846 \\
\hline lowa & $13(2.8)$ & $31(6.8)$ & $56(12.2)$ & $74(16.2)$ & $116(25.3)$ & $168(36.7)$ & 458 \\
\hline Kansas & $13(1.9)$ & $41(6.1)$ & $50(7.5)$ & $87(13.0)$ & $202(30.1)$ & $277(41.3)$ & 670 \\
\hline Kentucky & $16(4.5)$ & $24(6.8)$ & $36(10.2)$ & $43(12.2)$ & $97(27.5)$ & $137(38.8)$ & 353 \\
\hline Louisiana & $37(4.3)$ & $71(8.2)$ & $96(11.1)$ & $127(14.7)$ & $233(26.9)$ & $301(34.8)$ & 865 \\
\hline Maine & $5(2.4)$ & $6(2.8)$ & $23(10.9)$ & 35 (16.6) & $68(32.2)$ & $74(35.1)$ & 211 \\
\hline Michigan & $84(3.2)$ & $139(5.2)$ & $210(7.9)$ & $381(14.3)$ & $775(29.1)$ & $1,074(40.3)$ & 2,663 \\
\hline Minnesota & $18(2.1)$ & $46(5.3)$ & $63(7.2)$ & $119(13.6)$ & $245(28.1)$ & $381(43.7)$ & 872 \\
\hline Mississippi & $13(4.8)$ & $20(7.4)$ & $27(10.0)$ & $38(14.0)$ & 83 (30.6) & $90(33.2)$ & 271 \\
\hline Missouri & $14(2.8)$ & $26(5.3)$ & 47 (9.5) & $53(10.7)$ & $153(31.0)$ & $201(40.7)$ & 494 \\
\hline Montana & - & - & $25(12.3)$ & 40 (19.6) & $59(28.9)$ & $70(34.3)$ & 204 \\
\hline Nebraska & $7(3.5)$ & $9(4.5)$ & $16(8.0)$ & $35(17.4)$ & $66(32.8)$ & 68 (33.8) & 201 \\
\hline Nevada & $12(1.9)$ & $30(4.6)$ & $65(10.0)$ & $117(18.1)$ & $160(24.7)$ & $264(40.7)$ & 648 \\
\hline New Jersey ${ }^{\dagger \dagger}$ & $53(2.3)$ & $140(6.1)$ & $248(10.8)$ & $380(16.6)$ & $625(27.3)$ & $841(36.8)$ & 2,287 \\
\hline New Mexico & $24(3.8)$ & $34(5.3)$ & 85 (13.3) & 94 (14.7) & $161(25.2)$ & $240(37.6)$ & 638 \\
\hline New York & $241(2.5)$ & $479(5.0)$ & 875 (9.2) & $1,646(17.2)$ & $2,642(27.7)$ & $3,661(38.4)$ & 9,544 \\
\hline New York City & $153(2.6)$ & $292(4.9)$ & $573(9.6)$ & $1,029(17.3)$ & $1,598(26.9)$ & $2,304(38.7)$ & 5,949 \\
\hline New York State & $88(2.4)$ & $187(5.2)$ & $302(8.4)$ & $617(17.2)$ & $1,044(29.0)$ & $1,357(37.7)$ & 3,595 \\
\hline North Carolina & $70(2.7)$ & $122(4.8)$ & $235(9.2)$ & $385(15.1)$ & $760(29.7)$ & $984(38.5)$ & 2,556 \\
\hline North Dakota & $6(5.3)$ & $5(4.4)$ & $10(8.8)$ & $11(9.7)$ & $41(36.3)$ & $40(35.4)$ & 113 \\
\hline Ohio & $73(3.3)$ & $109(5.0)$ & $190(8.7)$ & $316(14.4)$ & $622(28.4)$ & $877(40.1)$ & 2,187 \\
\hline Oklahoma & $10(1.9)$ & $29(5.5)$ & 40 (7.6) & $93(17.7)$ & $152(29.0)$ & $201(38.3)$ & 525 \\
\hline Oregon & $21(2.3)$ & $35(3.8)$ & $72(7.8)$ & $140(15.2)$ & $257(27.9)$ & $397(43.1)$ & 922 \\
\hline Pennsylvania & $86(2.8)$ & $168(5.4)$ & $271(8.7)$ & $462(14.8)$ & $910(29.2)$ & $1,217(39.1)$ & 3,114 \\
\hline Rhode Island & $8(3.2)$ & $12(4.8)$ & $16(6.4)$ & 25 (10.0) & $71(28.5)$ & $117(47.0)$ & 249 \\
\hline South Carolina & $12(2.0)$ & $26(4.2)$ & $47(7.7)$ & $135(22.0)$ & $167(27.2)$ & $227(37.0)$ & 614 \\
\hline South Dakota & - & $5(11.9)$ & $8(19.0)$ & - & $9(21.4)$ & $16(38.1)$ & 42 \\
\hline Tennessee & $34(3.1)$ & $72(6.5)$ & $119(10.7)$ & $140(12.6)$ & $306(27.6)$ & 438 (39.5) & 1,109 \\
\hline Texas & $151(2.9)$ & $253(4.9)$ & $446(8.7)$ & 703 (13.6) & $1,522(29.5)$ & $2,077(40.3)$ & 5,152 \\
\hline Utah & $0(0.0)$ & $8(2.2)$ & $28(7.7)$ & 45 (12.4) & $112(30.9)$ & $170(46.8)$ & 363 \\
\hline Vermont & - & $7(5.4)$ & 15 (11.6) & - & $33(25.6)$ & $52(40.3)$ & 129 \\
\hline Virginia & $38(2.4)$ & $68(4.3)$ & $133(8.3)$ & $196(12.3)$ & $454(28.4)$ & $707(44.3)$ & 1,596 \\
\hline Washington & $36(1.9)$ & $88(4.5)$ & $199(10.3)$ & $322(16.6)$ & $562(29.0)$ & 734 (37.8) & 1,941 \\
\hline West Virginia & $6(4.0)$ & $11(7.3)$ & $12(7.9)$ & $19(12.6)$ & $40(26.5)$ & $63(41.7)$ & 151 \\
\hline Wisconsin ${ }^{* *}$ & $13(2.0)$ & $41(6.4)$ & $68(10.7)$ & $92(14.5)$ & $167(26.3)$ & $255(40.1)$ & 636 \\
\hline Total & $1,362(2.7)$ & $2,649(5.2)$ & 4,659 (9.2) & 7,715 (15.2) & $14,380(28.3)$ & $20,054(39.5)$ & 50,819 \\
\hline Abortion rate $\S^{\S \S}$ & 0.5 & 1.7 & 3.1 & 5.2 & 9.6 & 13.2 & - \\
\hline Abortion ratio & 684 & 447 & 327 & 285 & 292 & 247 & - \\
\hline
\end{tabular}

* Data from 45 reporting areas; excludes seven reporting areas (California, Florida, Illinois, Maryland, Massachusetts, New Hampshire, and Wyoming) that did not report, did not report age among adolescents by individual year, or did not meet reporting standards.

† Percentages for the individual component categories might not add to 100 because of rounding.

$\S$ Cells with a value in the range of 1-4 or cells that would allow for calculation of these small values have been suppressed.

" Because reporting is not mandatory, information could not be obtained for all abortions performed in the District of Columbia.

** Includes residents only.

${ }^{+\dagger}$ Data from hospitals and licensed ambulatory care facilities only; because reporting is not mandatory for private physicians and women's centers, information could not be obtained for all abortions performed in New Jersey.

$\S \S$ Number of abortions obtained by adolescents in a given age group per 1,000 adolescents in that same age group. Adolescents aged 13-14 years were used as the denominator for adolescents aged $<15$ years. For each reporting area, abortions for women of unknown age were distributed according to the distribution of abortions among women of known age for that area.

१ฯ Number of abortions obtained by adolescents in a given age group per 1,000 live births to adolescents in that same age group. For each reporting area, abortions for women of unknown age were distributed according to the distribution of abortions among women of known age for that area. 
TABLE 6. Reported abortions among adolescents, by known age and year — selected reporting areas, * United States, 2006-2015

\begin{tabular}{|c|c|c|c|c|c|c|c|c|c|c|c|c|c|c|}
\hline \multirow[b]{2}{*}{ Age (yrs) } & \multicolumn{10}{|c|}{ Year } & \multicolumn{4}{|c|}{$\%$ change } \\
\hline & 2006 & 2007 & 2008 & 2009 & 2010 & 2011 & 2012 & 2013 & 2014 & 2015 & $\begin{array}{c}2006 \text { to } \\
2010\end{array}$ & $\begin{array}{c}2011 \text { to } \\
2015\end{array}$ & $\begin{array}{c}2014 \text { to } \\
2015\end{array}$ & $\begin{array}{l}2006 \text { to } \\
2015\end{array}$ \\
\hline \multicolumn{15}{|c|}{$\%$ of abortions } \\
\hline$<15$ & 3.1 & 3.1 & 3.1 & 3.0 & 3.1 & 3.0 & 3.1 & 2.9 & 2.8 & 2.7 & 0.0 & -10.0 & -3.6 & -12.9 \\
\hline 15 & 6.1 & 6.0 & 5.8 & 5.6 & 5.8 & 5.6 & 5.6 & 5.2 & 5.2 & 5.2 & -4.9 & -7.1 & 0.0 & -14.8 \\
\hline 16 & 11.7 & 11.4 & 10.8 & 10.6 & 10.4 & 10.1 & 9.9 & 9.5 & 9.5 & 9.1 & -11.1 & -9.9 & -4.2 & -22.2 \\
\hline 17 & 17.3 & 17.4 & 17.2 & 16.9 & 16.4 & 16.1 & 15.7 & 15.2 & 15.1 & 15.2 & -5.2 & -5.6 & 0.7 & -12.1 \\
\hline 18 & 27.9 & 28.1 & 28.3 & 28.0 & 27.6 & 28.1 & 27.7 & 28.1 & 28.1 & 28.3 & -1.1 & 0.7 & 0.7 & 1.4 \\
\hline 19 & 33.9 & 34.0 & 34.8 & 35.8 & 36.7 & 37.2 & 38.1 & 39.2 & 39.2 & 39.5 & 8.3 & 6.2 & 0.8 & 16.5 \\
\hline \multicolumn{15}{|c|}{ Abortion rate $^{\dagger}$} \\
\hline$<15$ & 1.2 & 1.2 & 1.1 & 1.0 & 1.0 & 0.8 & 0.7 & 0.6 & 0.5 & 0.5 & -16.7 & -37.5 & 0.0 & -58.3 \\
\hline 15 & 4.5 & 4.4 & 4.2 & 3.8 & 3.6 & 3.1 & 2.6 & 2.2 & 1.9 & 1.7 & -20.0 & -45.2 & -10.5 & -62.2 \\
\hline 16 & 8.5 & 8.2 & 7.7 & 7.0 & 6.3 & 5.5 & 4.7 & 4.0 & 3.6 & 3.1 & -25.9 & -43.6 & -13.9 & -63.5 \\
\hline 17 & 13.1 & 12.4 & 12.2 & 11.1 & 9.9 & 8.6 & 7.3 & 6.3 & 5.6 & 5.2 & -24.4 & -39.5 & -7.1 & -60.3 \\
\hline 18 & 21.2 & 20.6 & 19.5 & 17.9 & 16.1 & 14.8 & 12.6 & 11.6 & 10.5 & 9.7 & -24.1 & -34.5 & -7.6 & -54.2 \\
\hline 19 & 25.7 & 25.0 & 24.6 & 22.3 & 21.0 & 18.9 & 17.0 & 15.7 & 14.2 & 13.3 & -18.3 & -29.6 & -6.3 & -48.2 \\
\hline \multicolumn{15}{|c|}{ Abortion ratio } \\
\hline$<15$ & 740 & 758 & 786 & 801 & 826 & 813 & 769 & 770 & 727 & 693 & 11.6 & -14.8 & -4.7 & -6.4 \\
\hline 15 & 517 & 493 & 510 & 494 & 529 & 507 & 469 & 451 & 460 & 448 & 2.3 & -11.6 & -2.6 & -13.3 \\
\hline 16 & 422 & 406 & 390 & 384 & 386 & 375 & 346 & 340 & 344 & 328 & -8.5 & -12.5 & -4.7 & -22.3 \\
\hline 17 & 345 & 337 & 332 & 324 & 324 & 320 & 294 & 288 & 283 & 288 & -6.1 & -10.0 & 1.8 & -16.5 \\
\hline 18 & 349 & 336 & 336 & 321 & 326 & 325 & 299 & 300 & 293 & 295 & -6.6 & -9.2 & 0.7 & -15.5 \\
\hline 19 & 302 & 290 & 294 & 287 & 292 & 281 & 262 & 260 & 253 & 250 & -3.3 & -11.0 & -1.2 & -17.2 \\
\hline Total (no.) & 111,491 & 109,693 & 107,671 & 98,784 & 89,979 & 78,845 & 67,707 & 60,221 & 53,967 & 49,526 & - & - & - & - \\
\hline
\end{tabular}

* Data from 40 reporting areas; by year, these areas represent 87\%-93\% of all abortions reported to CDC for adolescents during 2006-2015. Excludes 12 reporting areas (California, District of Columbia, Florida, Illinois, Louisiana, Maine, Maryland, Massachusetts, New Hampshire, Rhode Island, Vermont, and Wyoming) that did not report, did not report age among adolescents by individual year, or did not meet reporting standards for $\geq 1$ year.

t Number of abortions obtained by adolescents in a given age group per 1,000 adolescents in that same age group. Adolescents aged 13-14 years were used as the denominator for adolescents aged $<15$ years. For each reporting area, abortions for women of unknown age were distributed according to the distribution of abortions among women of known age for that area.

$\S$ Number of abortions obtained by adolescents in a given age group per 1,000 live births to adolescents in that same age group. For each reporting area, abortions for women of unknown age were distributed according to the distribution of abortions among women of known age for that area. 
TABLE 7. Reported abortions, by known weeks of gestation* and reporting area of occurrence — selected reporting areas, ${ }^{\dagger}$ United States, 2015

\begin{tabular}{|c|c|c|c|c|c|c|c|}
\hline \multirow[b]{3}{*}{ State/Area } & \multicolumn{6}{|c|}{ Weeks of gestation } & \multirow{2}{*}{$\begin{array}{c}\text { Total abortions } \\
\text { reported by known } \\
\text { gestational age }\end{array}$} \\
\hline & $\leq 8$ & $9-13$ & $14-15$ & $16-17$ & $18-20$ & $\geq 21$ & \\
\hline & No. $(\%)^{\S}$ & No. (\%) & No. (\%) & No. (\%) & No. (\%) & No. (\%) & $\begin{array}{l}\text { No. (\% of all reported } \\
\text { abortions) }{ }^{\uparrow}\end{array}$ \\
\hline Alabama & 3,191 (54.1) & $2,074(35.2)$ & $310(5.3)$ & $149(2.5)$ & $130(2.2)$ & $45(0.8)$ & $5,899(100.0)$ \\
\hline Alaska & 888 (66.7) & $439(33.0)$ & - ${ }^{* *}$ & $0(0.0)$ & - & - & 1,332 (99.9) \\
\hline Arizona & $8,335(65.9)$ & $3,198(25.3)$ & $468(3.7)$ & 243 (1.9) & $249(2.0)$ & $156(1.2)$ & $12,649(100.0)$ \\
\hline Arkansas $^{\dagger \dagger}$ & $2,065(54.8)$ & $1,068(28.3)$ & $232(6.2)$ & $175(4.6)$ & $196(5.2)$ & $35(0.9)$ & $3,771(100.0)$ \\
\hline Colorado & $7,300(72.4)$ & $1,959(19.4)$ & $299(3.0)$ & 155 (1.5) & $69(0.7)$ & $298(3.0)$ & $10,080(99.7)$ \\
\hline Delaware & $1,628(58.5)$ & $986(35.4)$ & $127(4.6)$ & $26(0.9)$ & $9(0.3)$ & $7(0.3)$ & 2,783 (99.9) \\
\hline Georgia & $19,312(62.3)$ & $8,208(26.5)$ & $1,069(3.4)$ & $831(2.7)$ & $859(2.8)$ & $730(2.4)$ & 31,009 (100.0) \\
\hline Hawaii & 1,025 (51.3) & $752(37.6)$ & $65(3.3)$ & $50(2.5)$ & 75 (3.8) & 31 (1.6) & 1,998 (98.6) \\
\hline Idaho & $832(65.4)$ & $398(31.3)$ & $34(2.7)$ & $8(0.6)$ & $0(0.0)$ & $0(0.0)$ & $1,272(100.0)$ \\
\hline Indiana & 4,799 (60.3) & 3,136 (39.4) & - & - & $5(0.1)$ & $6(0.1)$ & $7,955(100.0)$ \\
\hline lowa & $2,762(69.3)$ & $968(24.3)$ & $97(2.4)$ & $88(2.2)$ & $62(1.6)$ & $9(0.2)$ & 3,986 (99.9) \\
\hline Kansas & $4,345(62.7)$ & $1,970(28.4)$ & $233(3.4)$ & $162(2.3)$ & $176(2.5)$ & $45(0.6)$ & $6,931(100.0)$ \\
\hline Kentucky & $2,004(62.9)$ & $804(25.2)$ & $122(3.8)$ & 105 (3.3) & 107 (3.4) & $46(1.4)$ & $3,188(100.0)$ \\
\hline Louisiana & $6,188(66.6)$ & $2,428(26.1)$ & $399(4.3)$ & $189(2.0)$ & $76(0.8)$ & $17(0.2)$ & 9,297 (99.3) \\
\hline Maine & $1,093(59.5)$ & $648(35.3)$ & $37(2.0)$ & $28(1.5)$ & - & - & $1,836(100.0)$ \\
\hline Michigan & $16,822(62.0)$ & $7,210(26.6)$ & $1,305(4.8)$ & $745(2.7)$ & $603(2.2)$ & $430(1.6)$ & 27,115 (99.9) \\
\hline Minnesota & $6,542(66.3)$ & $2,381(24.1)$ & 358 (3.6) & $233(2.4)$ & $225(2.3)$ & $122(1.2)$ & $9,861(100.0)$ \\
\hline Mississippi & 1,740 (66.6) & 700 (26.8) & $144(5.5)$ & $29(1.1)$ & $0(0.0)$ & $0(0.0)$ & $2,613(100.0)$ \\
\hline Missouri & $2,624(55.1)$ & $1,522(31.9)$ & $196(4.1)$ & $154(3.2)$ & $192(4.0)$ & $77(1.6)$ & $4,765(100.0)$ \\
\hline Montana & $1,044(64.9)$ & 407 (25.3) & $62(3.9)$ & $47(2.9)$ & $40(2.5)$ & $8(0.5)$ & 1,608 (99.8) \\
\hline Nebraska & $1,304(65.1)$ & $544(27.1)$ & $91(4.5)$ & $46(2.3)$ & $19(0.9)$ & $0(0.0)$ & 2,004 (100.0) \\
\hline Nevada & 4,863 (69.1) & $1,696(24.1)$ & $234(3.3)$ & $123(1.7)$ & $90(1.3)$ & $31(0.4)$ & 7,037 (98.9) \\
\hline New Jersey§§ & $14,603(63.8)$ & $4,790(20.9)$ & $1,191(5.2)$ & $816(3.6)$ & 854 (3.7) & $640(2.8)$ & 22,894 (99.6) \\
\hline New Mexico & 3,087 (68.3) & 761 (16.8) & $126(2.8)$ & 87 (1.9) & $121(2.7)$ & $336(7.4)$ & 4,518 (96.8) \\
\hline New York City & $43,674(68.7)$ & $13,777(21.7)$ & $1,908(3.0)$ & $1,200(1.9)$ & $1,566(2.5)$ & $1,485(2.3)$ & $63,610(99.9)$ \\
\hline North Carolina & $17,969(66.7)$ & $6,725(25.0)$ & $1,097(4.1)$ & $718(2.7)$ & $396(1.5)$ & $17(0.1)$ & $26,922(97.4)$ \\
\hline North Dakota & 772 (66.2) & 339 (29.1) & $45(3.9)$ & $10(0.9)$ & $0(0.0)$ & $0(0.0)$ & 1,166 (100.0) \\
\hline Ohio & $10,910(52.0)$ & 7,485 (35.7) & $1,120(5.3)$ & 714 (3.4) & $602(2.9)$ & $145(0.7)$ & $20,976(100.0)$ \\
\hline Oklahoma & 3,661 (77.7) & 976 (20.7) & $68(1.4)$ & $0(0.0)$ & - & - & 4,709 (100.0) \\
\hline Oregon & $5,956(69.6)$ & $1,904(22.3)$ & $208(2.4)$ & $156(1.8)$ & $182(2.1)$ & $148(1.7)$ & $8,554(99.3)$ \\
\hline Rhode Island & $1,761(67.0)$ & $656(25.0)$ & $113(4.3)$ & $55(2.1)$ & $33(1.3)$ & $10(0.4)$ & $2,628(99.2)$ \\
\hline South Carolina & 4,143 (71.7) & $1,586(27.4)$ & $21(0.4)$ & - & $16(0.3)$ & - & $5,778(100.0)$ \\
\hline South Dakota & $248(56.0)$ & $186(42.0)$ & - & $0(0.0)$ & $5(1.1)$ & - & $443(99.8)$ \\
\hline Tennessee & $7,244(64.3)$ & 3,573 (31.7) & 404 (3.6) & $32(0.3)$ & $7(0.1)$ & $13(0.1)$ & $11,273(98.8)$ \\
\hline Texas $^{\dagger \dagger}$ & $34,831(64.6)$ & $14,673(27.2)$ & $2,207(4.1)$ & $1,123(2.1)$ & 855 (1.6) & $248(0.5)$ & $53,937(100.0)$ \\
\hline Utah & 2,239 (71.3) & $671(21.4)$ & $105(3.3)$ & $57(1.8)$ & $39(1.2)$ & $30(1.0)$ & 3,141 (98.9) \\
\hline Vermont & $906(71.7)$ & $305(24.1)$ & $26(2.1)$ & $7(0.6)$ & $11(0.9)$ & $9(0.7)$ & 1,264 (99.9) \\
\hline Virginia & $14,343(76.9)$ & $3,848(20.6)$ & $74(0.4)$ & $123(0.7)$ & $180(1.0)$ & $76(0.4)$ & 18,644 (99.9) \\
\hline Washington & $12,028(70.4)$ & $3,610(21.1)$ & $488(2.9)$ & 310 (1.8) & 321 (1.9) & 323 (1.9) & $17,080(99.9)$ \\
\hline West Virginia & $918(60.6)$ & $499(32.9)$ & $56(3.7)$ & $28(1.8)$ & - & - & $1,516(100.0)$ \\
\hline Total & $279,999(65.4)$ & $109,860(25.7)$ & $15,146(3.5)$ & $9,030(2.1)$ & $8,410(2.0)$ & $5,597(1.3)$ & $428,042(99.6)^{\text {ๆศ }}$ \\
\hline
\end{tabular}

* Gestational age based on the clinician's estimate (Alabama, Alaska, Arizona, Colorado, Delaware, Georgia, Hawaii, Idaho, Indiana, lowa, Kansas, Kentucky, Louisiana, Maine, Michigan, Minnesota, Mississippi, Missouri, Montana, Nebraska, Nevada, New Jersey, New Mexico, New York City, North Carolina, North Dakota, Ohio, Oregon, Rhode Island, South Carolina, South Dakota, Tennessee, Utah, Vermont, Washington, and West Virginia); gestational age calculated from the last normal menstrual period (Oklahoma); clinician's estimate of gestation based on estimated date of conception (Virginia); probable postfertilization age (Arkansas and Texas).

† Data are from 40 reporting areas; excludes 12 areas (California, Connecticut, District of Columbia, Florida, Illinois, Maryland, Massachusetts, New Hampshire, New York State, Pennsylvania, Wisconsin, and Wyoming) that did not report, did not report by gestational age, or did not meet reporting standards.

$\S$ Percentages for the individual component categories might not add to 100 because of rounding.

१ Percentage is calculated as the number of abortions reported by known gestational age divided by the sum of abortions reported by known and unknown gestational age.

** Cells with a value in the range of 1-4 or cells that would allow for calculation of these small values have been suppressed.

t+ Two weeks were added to the probable postfertilization age to provide a corresponding measure to gestational age based on the clinician's estimate.

$\S \S$ Data from hospitals and licensed ambulatory care facilities only; because reporting is not mandatory for private physicians and women's centers, information could not be obtained for all abortions performed in New Jersey.

१ศ Percentage based on a total of 429,587 abortions reported among the areas that met reporting standards for gestational age. 
TABLE 8. Reported abortions, by known weeks of gestation and year — selected reporting areas, ${ }^{*}$ United States, 2006-2015

\begin{tabular}{|c|c|c|c|c|c|c|c|c|c|c|c|c|c|c|}
\hline \multirow[b]{2}{*}{ Weeks of gestation } & \multicolumn{10}{|c|}{ Year } & \multicolumn{4}{|c|}{$\%$ change } \\
\hline & 2006 & 2007 & 2008 & 2009 & 2010 & 2011 & 2012 & 2013 & 2014 & 2015 & $\begin{array}{c}2006 \text { to } \\
2010\end{array}$ & $\begin{array}{c}2011 \text { to } \\
2015\end{array}$ & $\begin{array}{l}2014 \text { to } \\
2015\end{array}$ & $\begin{array}{c}2006 \text { to } \\
2015\end{array}$ \\
\hline$\leq 13$ weeks' gestation (\%) & 91.5 & 91.5 & 91.5 & 91.9 & 91.9 & 91.5 & 91.4 & 91.6 & 91.0 & 91.0 & 0.4 & -0.5 & 0.0 & -0.5 \\
\hline$\leq 8$ & 63.5 & 63.7 & 64.2 & 65.3 & 65.9 & 65.7 & 65.8 & 65.9 & 64.8 & 65.4 & 3.8 & -0.5 & 0.9 & 3.0 \\
\hline $9-13$ & 28.0 & 27.8 & 27.3 & 26.6 & 26.0 & 25.8 & 25.6 & 25.7 & 26.2 & 25.6 & -7.1 & -0.8 & -2.3 & -8.6 \\
\hline$>13$ weeks' gestation (\%) & 8.4 & 8.5 & 8.5 & 8.2 & 8.2 & 8.5 & 8.6 & 8.5 & 9.0 & 9.0 & -2.4 & 5.9 & 0.0 & 7.1 \\
\hline $14-15$ & 3.3 & 3.4 & 3.4 & 3.3 & 3.3 & 3.4 & 3.5 & 3.4 & 3.5 & 3.5 & 0.0 & 2.9 & 0.0 & 6.1 \\
\hline $16-17$ & 1.8 & 1.9 & 1.9 & 1.8 & 1.8 & 1.8 & 1.9 & 1.9 & 2.2 & 2.1 & 0.0 & 16.7 & -4.5 & 16.7 \\
\hline $18-20$ & 1.9 & 1.9 & 1.9 & 1.8 & 1.8 & 1.9 & 1.9 & 1.9 & 1.9 & 2.0 & -5.3 & 5.3 & 5.3 & 5.3 \\
\hline$\geq 21$ & 1.4 & 1.3 & 1.3 & 1.3 & 1.3 & 1.4 & 1.3 & 1.3 & 1.4 & 1.4 & -7.1 & 0.0 & 0.0 & 0.0 \\
\hline Total (no.) & 536,848 & 530,632 & 533,302 & 510,891 & 501,176 & 474,584 & 449,983 & 429,825 & 418,587 & 407,877 & - & - & - & - \\
\hline
\end{tabular}

* Data from 33 reporting areas; by year, these reporting areas represent $76 \%-85 \%$ of the abortions reported to CDC by gestational age during 2006-2015. Excludes 19 areas (California, Connecticut, Delaware, District of Columbia, Florida, Illinois, Maine, Maryland, Massachusetts, Mississippi, Nebraska, Nevada, New Hampshire, New York State, Pennsylvania, Rhode Island, Vermont, Wisconsin, and Wyoming) that did not report, did not report by gestational age, or did not meet reporting standards for $\geq 1$ year. 
TABLE 9. Reported abortions obtained at $\leq 13$ weeks' gestation,* by weeks of gestation and reporting area of occurrence - selected reporting areas, ${ }^{\dagger}$ United States, 2015

\begin{tabular}{|c|c|c|c|c|c|c|c|c|c|}
\hline \multirow[b]{3}{*}{ State/Area } & \multicolumn{8}{|c|}{ Weeks of gestation } & \multirow{3}{*}{$\begin{array}{l}\text { Total no. of } \\
\text { abortions a } \\
\leq 13 \text { weeks }\end{array}$} \\
\hline & $\leq 6$ & 7 & 8 & 9 & 10 & 11 & 12 & 13 & \\
\hline & No. $(\%)^{\S}$ & No. (\%) & No. (\%) & No. (\%) & No. (\%) & No. (\%) & No. (\%) & No. (\%) & \\
\hline Alabama & $1,131(21.5)$ & $1,091(20.7)$ & $969(18.4)$ & $640(12.2)$ & $507(9.6)$ & $372(7.1)$ & $275(5.2)$ & $280(5.3)$ & 5,265 \\
\hline Alaska & $387(29.2)$ & 259 (19.5) & $242(18.2)$ & $153(11.5)$ & 87 (6.6) & $54(4.1)$ & $72(5.4)$ & $73(5.5)$ & 1,327 \\
\hline Arizona & $3,699(32.1)$ & $2,676(23.2)$ & $1,960(17.0)$ & $1,117(9.7)$ & $743(6.4)$ & $681(5.9)$ & $343(3.0)$ & $314(2.7)$ & 11,533 \\
\hline Arkansas" & $938(29.9)$ & $591(18.9)$ & $536(17.1)$ & $384(12.3)$ & $245(7.8)$ & $214(6.8)$ & 109 (3.5) & $116(3.7)$ & 3,133 \\
\hline Colorado & $4,113(44.4)$ & $1,882(20.3)$ & $1,305(14.1)$ & 731 (7.9) & $464(5.0)$ & 340 (3.7) & $194(2.1)$ & $230(2.5)$ & 9,259 \\
\hline Delaware & $668(25.6)$ & $518(19.8)$ & $442(16.9)$ & $393(15.0)$ & $210(8.0)$ & $164(6.3)$ & $122(4.7)$ & 97 (3.7) & 2,614 \\
\hline Georgia & $9,272(33.7)$ & $6,008(21.8)$ & $4,032(14.7)$ & $2,659(9.7)$ & $1,826(6.6)$ & $1,558(5.7)$ & $1,304(4.7)$ & $861(3.1)$ & 27,520 \\
\hline Hawaii & $410(23.1)$ & $302(17.0)$ & $313(17.6)$ & $248(14.0)$ & $155(8.7)$ & $125(7.0)$ & $112(6.3)$ & $112(6.3)$ & 1,777 \\
\hline Idaho & $330(26.8)$ & $270(22.0)$ & $232(18.9)$ & $152(12.4)$ & $96(7.8)$ & $65(5.3)$ & $39(3.2)$ & 46 (3.7) & 1,230 \\
\hline Indiana & $1,454(18.3)$ & $1,733(21.8)$ & $1,612(20.3)$ & $986(12.4)$ & $687(8.7)$ & $575(7.2)$ & $444(5.6)$ & $444(5.6)$ & 7,935 \\
\hline lowa & $1,348(36.1)$ & $790(21.2)$ & $624(16.7)$ & $306(8.2)$ & $209(5.6)$ & $176(4.7)$ & $157(4.2)$ & $120(3.2)$ & 3,730 \\
\hline Kansas & $2,120(33.6)$ & $1,320(20.9)$ & 905 (14.3) & $699(11.1)$ & $423(6.7)$ & $367(5.8)$ & $282(4.5)$ & 199 (3.2) & 6,315 \\
\hline Kentucky & $847(30.2)$ & $661(23.5)$ & 496 (17.7) & $300(10.7)$ & $169(6.0)$ & $155(5.5)$ & $101(3.6)$ & $79(2.8)$ & 2,808 \\
\hline Louisiana & $3,098(36.0)$ & $1,909(22.2)$ & $1,181(13.7)$ & 835 (9.7) & $501(5.8)$ & $464(5.4)$ & 333 (3.9) & 295 (3.4) & 8,616 \\
\hline Maine & $327(18.8)$ & $422(24.2)$ & $344(19.8)$ & $225(12.9)$ & $154(8.8)$ & $90(5.2)$ & $109(6.3)$ & $70(4.0)$ & 1,741 \\
\hline Michigan & $8,092(33.7)$ & 4,791 (19.9) & 3,939 (16.4) & $2,692(11.2)$ & $1,390(5.8)$ & $1,130(4.7)$ & $1,100(4.6)$ & 898 (3.7) & 24,032 \\
\hline Minnesota & $3,378(37.9)$ & $1,792(20.1)$ & $1,372(15.4)$ & $935(10.5)$ & $511(5.7)$ & $428(4.8)$ & $288(3.2)$ & $219(2.5)$ & 8,923 \\
\hline Mississippi & $804(33.0)$ & $573(23.5)$ & $363(14.9)$ & $256(10.5)$ & $137(5.6)$ & $138(5.7)$ & $90(3.7)$ & 79 (3.2) & 2,440 \\
\hline Missouri & $904(21.8)$ & 991 (23.9) & 729 (17.6) & $588(14.2)$ & $303(7.3)$ & $326(7.9)$ & $192(4.6)$ & $113(2.7)$ & 4,146 \\
\hline Montana & $591(40.7)$ & $240(16.5)$ & $213(14.7)$ & $153(10.5)$ & $78(5.4)$ & $67(4.6)$ & $62(4.3)$ & 47 (3.2) & 1,451 \\
\hline Nebraska & $920(49.8)$ & $179(9.7)$ & $205(11.1)$ & $150(8.1)$ & $110(6.0)$ & $108(5.8)$ & $107(5.8)$ & $69(3.7)$ & 1,848 \\
\hline Nevada & 2,589 (39.5) & 1,291 (19.7) & $983(15.0)$ & 740 (11.3) & $371(5.7)$ & $308(4.7)$ & $143(2.2)$ & $134(2.0)$ & 6,559 \\
\hline New Jersey** & $8,421(43.4)$ & 3,717 (19.2) & $2,465(12.7)$ & 1,596 (8.2) & $1,008(5.2)$ & 654 (3.4) & $796(4.1)$ & 736 (3.8) & 19,393 \\
\hline New Mexico & $2,099(54.5)$ & 571 (14.8) & $417(10.8)$ & $238(6.2)$ & $195(5.1)$ & $128(3.3)$ & $120(3.1)$ & $80(2.1)$ & 3,848 \\
\hline New York City & $24,560(42.7)$ & 11,101 (19.3) & $8,013(13.9)$ & $5,120(8.9)$ & $3,234(5.6)$ & $2,407(4.2)$ & $1,889(3.3)$ & $1,127(2.0)$ & 57,451 \\
\hline North Carolina & $8,741(35.4)$ & $5,161(20.9)$ & $4,067(16.5)$ & $2,315(9.4)$ & $1,489(6.0)$ & $1,139(4.6)$ & 962 (3.9) & $820(3.3)$ & 24,694 \\
\hline North Dakota & $382(34.4)$ & $227(20.4)$ & $163(14.7)$ & $139(12.5)$ & $67(6.0)$ & $55(5.0)$ & $44(4.0)$ & $34(3.1)$ & 1,111 \\
\hline Ohio & $4,500(24.5)$ & $3,534(19.2)$ & $2,876(15.6)$ & $2,367(12.9)$ & $1,743(9.5)$ & $1,468(8.0)$ & $1,054(5.7)$ & $853(4.6)$ & 18,395 \\
\hline Oklahoma & $2,857(61.6)$ & $422(9.1)$ & $382(8.2)$ & $339(7.3)$ & $176(3.8)$ & $222(4.8)$ & $174(3.8)$ & 65 (1.4) & 4,637 \\
\hline Oregon & $3,376(43.0)$ & $1,452(18.5)$ & $1,128(14.4)$ & $669(8.5)$ & $394(5.0)$ & 304 (3.9) & 284 (3.6) & $253(3.2)$ & 7,860 \\
\hline Rhode Island & $1,088(45.0)$ & $414(17.1)$ & $259(10.7)$ & $231(9.6)$ & $138(5.7)$ & $131(5.4)$ & $61(2.5)$ & 95 (3.9) & 2,417 \\
\hline South Carolina & $2,192(38.3)$ & $1,068(18.6)$ & $883(15.4)$ & $516(9.0)$ & $372(6.5)$ & $347(6.1)$ & 207 (3.6) & $144(2.5)$ & 5,729 \\
\hline South Dakota & $88(20.3)$ & $88(20.3)$ & $72(16.6)$ & $71(16.4)$ & $34(7.8)$ & $27(6.2)$ & $16(3.7)$ & $38(8.8)$ & 434 \\
\hline Tennessee & $3,353(31.0)$ & $2,183(20.2)$ & $1,708(15.8)$ & $1,217(11.3)$ & 789 (7.3) & 771 (7.1) & 415 (3.8) & 381 (3.5) & 10,817 \\
\hline Texas & $19,450(39.3)$ & $8,851(17.9)$ & $6,530(13.2)$ & $5,024(10.1)$ & $3,562(7.2)$ & $2,835(5.7)$ & $1,707(3.4)$ & $1,545(3.1)$ & 49,504 \\
\hline Utah & $1,255(43.1)$ & $582(20.0)$ & $402(13.8)$ & $230(7.9)$ & $156(5.4)$ & $139(4.8)$ & $89(3.1)$ & $57(2.0)$ & 2,910 \\
\hline Vermont & $402(33.2)$ & $281(23.2)$ & $223(18.4)$ & $126(10.4)$ & $63(5.2)$ & $53(4.4)$ & $33(2.7)$ & $30(2.5)$ & 1,211 \\
\hline Virginia & $9,479(52.1)$ & $2,909(16.0)$ & $1,955(10.7)$ & $1,393(7.7)$ & $930(5.1)$ & $766(4.2)$ & 479 (2.6) & $280(1.5)$ & 18,191 \\
\hline Washington & $6,512(41.6)$ & $3,180(20.3)$ & 2,336 (14.9) & 1,203 (7.7) & $789(5.0)$ & $700(4.5)$ & $441(2.8)$ & 477 (3.1) & 15,638 \\
\hline West Virginia & $351(24.8)$ & 335 (23.6) & $232(16.4)$ & 161 (11.4) & $108(7.6)$ & $91(6.4)$ & $103(7.3)$ & $36(2.5)$ & 1,417 \\
\hline Total & $146,526(37.6)$ & 76,365 (19.6) & $57,108(14.6)$ & $38,297(9.8)$ & $24,623(6.3)$ & $20,142(5.2)$ & $14,852(3.8)$ & $11,946(3.1)$ & 389,859 \\
\hline
\end{tabular}

\footnotetext{
* Gestational age based on the clinician's estimate (Alabama, Alaska, Arizona, Colorado, Delaware, Georgia, Hawaii, Idaho, Indiana, lowa, Kansas, Kentucky, Louisiana, Maine, Michigan, Minnesota, Mississippi, Missouri, Montana, Nebraska, Nevada, New Jersey, New Mexico, New York City, North Carolina, North Dakota, Ohio, Oregon, Rhode Island, South Carolina, South Dakota, Tennessee, Utah, Vermont, Washington, and West Virginia); gestational age calculated from the last normal menstrual period (Oklahoma); clinician's estimate of gestation based on estimated date of conception (Virginia); probable postfertilization age (Arkansas and Texas).

† Data are from 40 reporting areas; excludes 12 areas (California, Connecticut, District of Columbia, Florida, Illinois, Maryland, Massachusetts, New Hampshire, New York State, Pennsylvania, Wisconsin, and Wyoming) that did not report, did not report by gestational age, or did not meet reporting standards.

$\S$ Percentages for the individual component categories might not add to 100 because of rounding.

I Two weeks were added to the probable postfertilization age to provide a corresponding measure to gestational age based on the clinician's estimate.

** Data from hospitals and licensed ambulatory care facilities only; because reporting is not mandatory for private physicians and women's centers, information could not be obtained for all abortions performed in New Jersey.
} 
TABLE 10. Reported abortions obtained at $\leq 13$ weeks' gestation, by weeks of gestation and year — selected reporting areas,* United States, 2006-2015

\begin{tabular}{|c|c|c|c|c|c|c|c|c|c|c|c|c|c|c|}
\hline \multirow[b]{2}{*}{$\begin{array}{l}\text { Weeks of } \\
\text { gestation }\end{array}$} & \multicolumn{10}{|c|}{ Year } & \multicolumn{4}{|c|}{ \% change } \\
\hline & 2006 & 2007 & 2008 & 2009 & 2010 & 2011 & 2012 & 2013 & 2014 & 2015 & $\begin{array}{c}2006 \text { to } \\
2010\end{array}$ & $\begin{array}{c}2011 \text { to } \\
2015\end{array}$ & $\begin{array}{c}2014 \text { to } \\
2015\end{array}$ & $\begin{array}{c}2006 \text { to } \\
2015\end{array}$ \\
\hline \multicolumn{15}{|c|}{$\%$ distribution among abortions reported at $\leq 13$ weeks } \\
\hline$\leq 6$ & 34.0 & 35.0 & 35.5 & 36.7 & 37.9 & 37.6 & 38.4 & 37.9 & 37.1 & 37.7 & 11.5 & 0.3 & 1.6 & 10.9 \\
\hline 7 & 20.1 & 20.0 & 19.8 & 19.4 & 19.3 & 19.6 & 19.3 & 19.5 & 19.3 & 19.6 & -4.0 & 0.0 & 1.6 & -2.5 \\
\hline 8 & 15.2 & 14.7 & 14.8 & 14.9 & 14.5 & 14.6 & 14.3 & 14.6 & 14.9 & 14.6 & -4.6 & 0.0 & -2.0 & -3.9 \\
\hline 9 & 10.4 & 10.2 & 10.0 & 9.7 & 9.8 & 9.5 & 9.4 & 9.4 & 9.8 & 9.8 & -5.8 & 3.2 & 0.0 & -5.8 \\
\hline 10 & 7.4 & 7.4 & 7.1 & 6.8 & 6.7 & 6.5 & 6.4 & 6.4 & 6.6 & 6.3 & -9.5 & -3.1 & -4.5 & -14.9 \\
\hline 11 & 5.4 & 5.4 & 5.5 & 5.3 & 5.1 & 5.2 & 5.2 & 5.1 & 5.4 & 5.2 & -5.6 & 0.0 & -3.7 & -3.7 \\
\hline 12 & 4.3 & 4.3 & 4.2 & 4.1 & 3.9 & 4.0 & 3.9 & 4.0 & 3.9 & 3.8 & -9.3 & -5.0 & -2.6 & -11.6 \\
\hline 13 & 3.1 & 3.1 & 3.0 & 2.9 & 2.9 & 3.0 & 3.1 & 3.1 & 3.1 & 3.1 & -6.5 & 3.3 & 0.0 & 0.0 \\
\hline Total (no.) & 491,630 & 485,709 & 487,837 & 469,055 & 460,424 & 434,216 & 411,526 & 393,570 & 380,683 & 371,029 & - & - & - & - \\
\hline
\end{tabular}

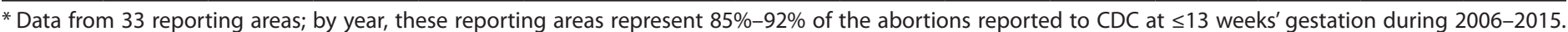

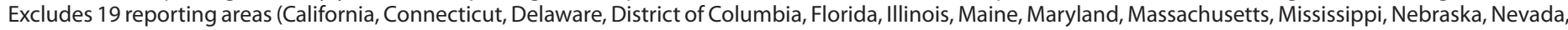

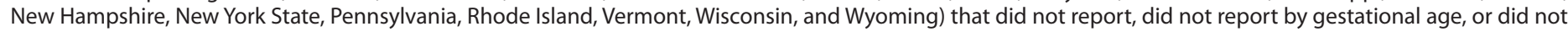
meet reporting standards for $\geq 1$ year. 
TABLE 11. Reported abortions, by known method type and reporting area of occurrence — selected reporting areas, ${ }^{*}$ United States, 2015

\begin{tabular}{|c|c|c|c|c|c|c|c|c|c|}
\hline \multirow[b]{3}{*}{ State/Area } & \multicolumn{3}{|c|}{ Surgical $^{\dagger}$} & \multicolumn{3}{|c|}{ Medical } & \multirow[b]{2}{*}{$\begin{array}{l}\text { Intrauterine } \\
\text { instillation } \$\end{array}$} & \multirow[b]{2}{*}{$\begin{array}{l}\text { Hysterectomy/ } \\
\text { Hysterotomy }\end{array}$} & \multirow[b]{2}{*}{$\begin{array}{c}\text { Total abortions } \\
\text { reported by known } \\
\text { method type }\end{array}$} \\
\hline & $\begin{array}{c}\text { Surgical, } \\
\leq 13 \text { weeks' } \\
\text { gestation } \\
\end{array}$ & $\begin{array}{c}\text { Surgical, } \\
>13 \text { weeks' } \\
\text { gestation } \\
\end{array}$ & $\begin{array}{c}\begin{array}{c}\text { Surgical, } \\
\text { unknown } \\
\text { gestational age }\end{array} \\
\end{array}$ & $\begin{array}{l}\text { Medical, } \\
\leq 8 \text { weeks' } \\
\text { gestation }\end{array}$ & $\begin{array}{l}\text { Medical, } \\
>8 \text { weeks' } \\
\text { gestation }\end{array}$ & $\begin{array}{c}\text { Medical, } \\
\text { unknown } \\
\text { gestational } \\
\text { age } \\
\end{array}$ & & & \\
\hline & No. (\%)ף & No. (\%) & No. (\%) & No. (\%) & No. (\%) & No. (\%) & No. (\%) & No. (\%) & $\begin{array}{c}\text { No. (\% of all reported } \\
\text { abortions) })^{* *}\end{array}$ \\
\hline Alabama & $3,355(56.9)$ & $614(10.4)$ & $0(0.0)$ & $1,831(31.0)$ & $95(1.6)$ & $0(0.0)$ & $-^{\dagger+}$ & - & $5,897(100.0)$ \\
\hline Alaska & 984 (73.9) & - & - & $302(22.7)$ & $38(2.9)$ & - & - & $0(0.0)$ & $1,331(99.8)$ \\
\hline Arizona & $7,494(59.3)$ & $1,089(8.6)$ & - & $3,868(30.6)$ & $178(1.4)$ & - & - & $0(0.0)$ & $12,636(99.8)$ \\
\hline Arkansas & $2,552(67.7)$ & 638 (16.9) & $0(0.0)$ & $548(14.5)$ & $33(0.9)$ & $0(0.0)$ & $0(0.0)$ & $0(0.0)$ & $3,771(100.0)$ \\
\hline Colorado & $4,826(49.1)$ & $539(5.5)$ & $23(0.2)$ & $4,222(42.9)$ & $212(2.2)$ & $10(0.1)$ & - & - & $9,833(97.2)$ \\
\hline Connecticut ${ }^{\S \S}$ & NA & NA & $5,544(55.8)$ & NA & NA & $4,392(44.2)$ & - & - & $9,938(100.0)$ \\
\hline Delaware & $1,415(51.0)$ & $164(5.9)$ & - & $1,031(37.1)$ & $163(5.9)$ & $0(0.0)$ & - & $0(0.0)$ & 2,776 (99.7) \\
\hline \multicolumn{10}{|l|}{ District of } \\
\hline Columbia१ๆ & 845 (66.7) & $159(12.5)$ & $0(0.0)$ & $0(0.0)$ & $22(1.7)$ & $241(19.0)$ & $0(0.0)$ & $0(0.0)$ & $1,267(100.0)$ \\
\hline Georgia & $19,758(64.1)$ & $3,478(11.3)$ & $0(0.0)$ & $7,186(23.3)$ & $382(1.2)$ & $0(0.0)$ & $0(0.0)$ & $0(0.0)$ & $30,804(99.3)$ \\
\hline Idaho & $670(52.7)$ & $41(3.2)$ & $0(0.0)$ & $497(39.1)$ & $64(5.0)$ & $0(0.0)$ & $0(0.0)$ & $0(0.0)$ & $1,272(100.0)$ \\
\hline Illinois $§ \S$ & NA & NA & $24,811(72.2)$ & NA & NA & $9,514(27.7)$ & $53(0.2)$ & $0(0.0)$ & $34,378(86.3)$ \\
\hline Indiana & $5,714(71.8)$ & $20(0.3)$ & - & 2,115 (26.6) & $106(1.3)$ & - & $0(0.0)$ & $0(0.0)$ & $7,957(100.0)$ \\
\hline lowa & $1,546(38.8)$ & $254(6.4)$ & - & $2,076(52.2)$ & $101(2.5)$ & - & $0(0.0)$ & $0(0.0)$ & $3,980(99.8)$ \\
\hline Kansas & $3,223(46.5)$ & 612 (8.8) & $0(0.0)$ & $2,673(38.6)$ & $419(6.0)$ & $0(0.0)$ & $0(0.0)$ & $0(0.0)$ & 6,927 (99.9) \\
\hline Kentucky & $1,597(50.1)$ & 373 (11.7) & $0(0.0)$ & $1,157(36.3)$ & 61 (1.9) & $0(0.0)$ & $0(0.0)$ & $0(0.0)$ & $3,188(100.0)$ \\
\hline Maine & $1,209(65.8)$ & $85(4.6)$ & $0(0.0)$ & 417 (22.7) & $125(6.8)$ & $0(0.0)$ & $0(0.0)$ & $0(0.0)$ & $1,836(100.0)$ \\
\hline Massachusetts ${ }^{\S}$ & NA & NA & $12,933(70.3)$ & NA & NA & $5,324(28.9)$ & $145(0.8)$ & $0(0.0)$ & $18,402(99.1)$ \\
\hline Michigan & $16,523(61.0)$ & $3,023(11.2)$ & $29(0.1)$ & $6,737(24.9)$ & 775 (2.9) & $5(0.0)$ & - & - & $27,095(99.8)$ \\
\hline Minnesota & $5,774(58.6)$ & $920(9.3)$ & $0(0.0)$ & $2,833(28.7)$ & $326(3.3)$ & $0(0.0)$ & - & - & $9,861(100.0)$ \\
\hline Mississippi & $1,232(47.1)$ & 172 (6.6) & $0(0.0)$ & $1,057(40.5)$ & $152(5.8)$ & $0(0.0)$ & $0(0.0)$ & $0(0.0)$ & $2,613(100.0)$ \\
\hline Missouri & $2,891(60.7)$ & 609 (12.8) & $0(0.0)$ & $1,065(22.4)$ & $198(4.2)$ & $0(0.0)$ & - & - & $4,764(100.0)$ \\
\hline Montana & $672(41.7)$ & 157 (9.7) & - & 724 (44.9) & 55 (3.4) & $0(0.0)$ & $0(0.0)$ & - & $1,611(100.0)$ \\
\hline Nebraska & $885(44.2)$ & $154(7.7)$ & $0(0.0)$ & $922(46.0)$ & $43(2.1)$ & $0(0.0)$ & $0(0.0)$ & $0(0.0)$ & $2,004(100.0)$ \\
\hline Nevada & 4,938 (72.7) & $263(3.9)$ & $41(0.6)$ & $1,456(21.4)$ & $64(0.9)$ & $31(0.5)$ & $0(0.0)$ & $0(0.0)$ & $6,793(95.5)$ \\
\hline New Jersey*** & $15,281(66.5)$ & $3,442(15.0)$ & $88(0.4)$ & $3,854(16.8)$ & $280(1.2)$ & - & - & $35(0.2)$ & $22,988(100.0)$ \\
\hline New York & $59,533(64.8)$ & 7,332 (8.0) & $4,677(5.1)$ & $15,667(17.1)$ & 3,107 (3.4) & $1,462(1.6)$ & $71(0.1)$ & $11(0.0)$ & $91,860(98.7)$ \\
\hline New York City & $46,636(73.4)$ & $5,883(9.3)$ & $25(0.0)$ & $10,267(16.2)$ & $644(1.0)$ & $9(0.0)$ & $45(0.1)$ & $11(0.0)$ & $63,520(99.8)$ \\
\hline New York State & $12,897(45.5)$ & $1,449(5.1)$ & $4,652(16.4)$ & $5,400(19.1)$ & $2,463(8.7)$ & $1,453(5.1)$ & $26(0.1)$ & $0(0.0)$ & $28,340(96.2)$ \\
\hline North Carolina & $13,606(51.1)$ & $2,118(7.9)$ & $194(0.7)$ & $9,721(36.5)$ & $577(2.2)$ & 428 (1.6) & $0(0.0)$ & $0(0.0)$ & $26,644(96.4)$ \\
\hline North Dakota & $1,065(91.3)$ & $54(4.6)$ & $0(0.0)$ & $30(2.6)$ & $15(1.3)$ & $0(0.0)$ & - & - & $1,166(100.0)$ \\
\hline Ohio & $17,240(82.2)$ & $2,556(12.2)$ & $0(0.0)$ & $1,154(5.5)$ & $26(0.1)$ & $0(0.0)$ & $0(0.0)$ & $0(0.0)$ & $20,976(100.0)$ \\
\hline
\end{tabular}

See table footnotes on the next page. 
TABLE 11. (Continued) Reported abortions, by known method type and reporting area of occurrence - selected reporting areas, ${ }^{*}$ United States, 2015

\begin{tabular}{|c|c|c|c|c|c|c|c|c|c|}
\hline \multirow[b]{3}{*}{ State/Area } & \multicolumn{3}{|c|}{ Surgical $^{\dagger}$} & \multicolumn{3}{|c|}{ Medical } & \multirow[b]{2}{*}{$\begin{array}{l}\text { Intrauterine } \\
\text { instillation } \\
\end{array}$} & \multirow[b]{2}{*}{$\begin{array}{l}\text { Hysterectomy/ } \\
\text { Hysterotomy }\end{array}$} & \multirow[b]{2}{*}{$\begin{array}{c}\text { Total abortions } \\
\text { reported by known } \\
\text { method type } \\
\end{array}$} \\
\hline & $\begin{array}{l}\text { Surgical, } \\
\leq 13 \text { weeks' } \\
\text { gestation }\end{array}$ & $\begin{array}{l}\text { Surgical, } \\
>13 \text { weeks' } \\
\text { gestation }\end{array}$ & $\begin{array}{c}\text { Surgical, } \\
\text { unknown } \\
\text { gestational age }\end{array}$ & $\begin{array}{l}\text { Medical, } \\
\leq 8 \text { weeks' } \\
\text { gestation }\end{array}$ & $\begin{array}{l}\text { Medical, } \\
\text { >8 weeks' } \\
\text { gestation }\end{array}$ & $\begin{array}{c}\text { Medical, } \\
\text { unknown } \\
\text { gestational } \\
\text { age }\end{array}$ & & & \\
\hline & No. $(\%)^{q}$ & No. (\%) & No. (\%) & No. (\%) & No. (\%) & No. (\%) & No. (\%) & No. (\%) & $\begin{array}{l}\text { No. (\% of all reported } \\
\text { abortions) }{ }^{* *}\end{array}$ \\
\hline Oklahoma & $2,792(59.6)$ & $66(1.4)$ & $0(0.0)$ & $1,822(38.9)$ & - & $0(0.0)$ & - & $0(0.0)$ & 4,686 (99.5) \\
\hline Oregon & $4,675(54.4)$ & $658(7.7)$ & $40(0.5)$ & $3,045(35.4)$ & $162(1.9)$ & $15(0.2)$ & - & - & $8,598(99.9)$ \\
\hline Pennsylvania & $16,651(52.3)$ & $3,846(12.1)$ & $0(0.0)$ & $10,033(31.5)$ & $1,281(4.0)$ & $0(0.0)$ & $0(0.0)$ & $0(0.0)$ & $31,811(100.0)$ \\
\hline Rhode Island & $1,615(61.4)$ & $206(7.8)$ & $11(0.4)$ & $714(27.2)$ & $73(2.8)$ & $10(0.4)$ & $0(0.0)$ & $0(0.0)$ & $2,629(99.2)$ \\
\hline South Carolina & $3,022(52.3)$ & $37(0.6)$ & $0(0.0)$ & $2,585(44.8)$ & $127(2.2)$ & $0(0.0)$ & - & - & $5,775(99.9)$ \\
\hline South Dakota & $266(59.9)$ & - & - & $138(31.1)$ & 38 (8.6) & $0(0.0)$ & $0(0.0)$ & $0(0.0)$ & $444(100.0)$ \\
\hline Texas & $43,545(80.7)$ & $4,369(8.1)$ & - & $5,917(11.0)$ & $86(0.2)$ & - & - & - & $53,926(100.0)$ \\
\hline Utah & $1,822(57.6)$ & $216(6.8)$ & $11(0.3)$ & $1,005(31.8)$ & $83(2.6)$ & $24(0.8)$ & $0(0.0)$ & $0(0.0)$ & $3,161(99.5)$ \\
\hline Vermont & $587(46.6)$ & $48(3.8)$ & - & $548(43.5)$ & $77(6.1)$ & $0(0.0)$ & $0(0.0)$ & - & $1,261(99.7)$ \\
\hline Virginia & $13,050(70.0)$ & $437(2.3)$ & $12(0.1)$ & $5,060(27.2)$ & $69(0.4)$ & $7(0.0)$ & - & - & 18,636 (99.9) \\
\hline Washington & $10,005(58.5)$ & $1,435(8.4)$ & $11(0.1)$ & $5,352(31.3)$ & $281(1.6)$ & $7(0.0)$ & $0(0.0)$ & $0(0.0)$ & $17,091(100.0)$ \\
\hline West Virginia & 1,212 (79.9) & $93(6.1)$ & $0(0.0)$ & $199(13.1)$ & $12(0.8)$ & $0(0.0)$ & $0(0.0)$ & $0(0.0)$ & 1,516 (100.0) \\
\hline Wisconsin $\S \S,+† \dagger$ & NA & NA & $4,323(79.2)$ & NA & NA & $1,138(20.8)$ & NA & NA & $5,461(96.5)$ \\
\hline Total & $340,475(64.3)$ & $46,637(8.8)$ & —§§§ & $130,309(24.6)$ & $11,785(2.2)$ & — १งๆ & $298(0.1)$ & $59(0.0)$ & $529,563(98.3)^{* * * *}$ \\
\hline
\end{tabular}

Abbreviation: $\mathrm{NA}=$ not available.

* Data from 43 reporting areas; excludes nine reporting areas (California, Florida, Hawaii, Louisiana, Maryland, New Hampshire, New Mexico, Tennessee, and Wyoming) that did not report, did not report by method type, or did not meet reporting standards.

${ }^{\dagger}$ Includes aspiration curettage, suction curettage, manual vacuum aspiration, menstrual extraction, sharp curettage, and dilation and evacuation procedures.

$\S$ Intrauterine instillations reported at $\leq 12$ weeks' gestation are not presented with abortions reported by known method type.

" Percentages for the individual component categories might not add to 100 because of rounding.

** Percentage is calculated as the number of abortions reported by known method type divided by the sum of abortions reported by known and unknown method type.

${ }^{+\dagger}$ Cells with a value in the range of 1-4 or cells that would allow for calculation of these small values have been suppressed.

$\S \S$ Numbers for surgical procedures at $\leq 13$ weeks versus $>13$ weeks and for medical abortion at $\leq 8$ weeks versus $>8$ weeks are not presented because gestational age data were not provided or were provided in incompatible categories.

१ๆ Because reporting is not mandatory, information could not be obtained for all abortions performed in the District of Columbia.

*** Data from hospitals and licensed ambulatory care facilities only; because reporting is not mandatory for private physicians and women's centers, information could not be obtained for all abortions performed in New Jersey.

${ }^{++\dagger}$ All abortions were reported as surgical or chemically induced. For this report, all surgical abortions were classified as surgical and all chemical abortions as medical.

$\S \S$ Surgical abortions reported without a gestational age were distributed among the surgical abortion categories according to the distribution of surgical abortions at known gestational age.

ๆศศ Medical abortions reported without a gestational age were distributed among the medical abortion categories according to the distribution of medical abortions at known gestational age.

**** Percentage is based on a total of 538,678 abortions reported among the areas that met reporting standards for method type. 
TABLE 12. Reported abortions, by known race/ethnicity of women who obtained an abortion and reporting area of occurrence - selected reporting areas, * United States, 2015

\begin{tabular}{|c|c|c|c|c|c|}
\hline \multirow[b]{3}{*}{ State/Area } & \multicolumn{3}{|c|}{ Non-Hispanic } & \multirow[b]{2}{*}{ Hispanic } & \multirow{3}{*}{$\begin{array}{c}\begin{array}{c}\text { Total abortions reported } \\
\text { by known race/ethnicity }\end{array} \\
\begin{array}{c}\text { No. (\% of all reported } \\
\text { abortions) }\end{array}\end{array}$} \\
\hline & White & Black & Other & & \\
\hline & No. $(\%)^{\dagger}$ & No. (\%) & No. (\%) & No. (\%) & \\
\hline Alabama & $1,905(32.4)$ & $3,490(59.3)$ & $186(3.2)$ & $302(5.1)$ & $5,883(99.7)$ \\
\hline Alaska & $743(62.2)$ & $88(7.4)$ & $337(28.2)$ & $27(2.3)$ & $1,195(89.6)$ \\
\hline Arizona & $5,425(45.2)$ & $1,090(9.1)$ & $1,040(8.7)$ & $4,437(37.0)$ & $11,992(94.8)$ \\
\hline Arkansas & $1,631(45.4)$ & $1,734(48.3)$ & $5(0.1)$ & $221(6.2)$ & 3,591 (95.2) \\
\hline Colorado & $5,112(57.9)$ & $672(7.6)$ & $698(7.9)$ & $2,349(26.6)$ & $8,831(87.3)$ \\
\hline Delaware & $1,158(41.7)$ & $1,175(42.3)$ & $165(5.9)$ & $282(10.1)$ & $2,780(99.8)$ \\
\hline District of Columbia? & 189 (15.8) & 857 (71.5) & 55 (4.6) & $98(8.2)$ & $1,199(94.6)$ \\
\hline Georgia & $7,183(24.7)$ & $18,167(62.4)$ & $1,572(5.4)$ & $2,179(7.5)$ & $29,101(93.8)$ \\
\hline Hawaii & $394(21.9)$ & $70(3.9)$ & $1,120(62.3)$ & $213(11.9)$ & 1,797 (88.7) \\
\hline Idaho & $897(78.1)$ & $22(1.9)$ & $45(3.9)$ & $184(16.0)$ & $1,148(90.3)$ \\
\hline Indiana & $4,384(55.1)$ & $2,364(29.7)$ & $565(7.1)$ & $644(8.1)$ & $7,957(100.0)$ \\
\hline Kansas & $3,884(56.3)$ & $1,477(21.4)$ & $640(9.3)$ & $899(13.0)$ & $6,900(99.6)$ \\
\hline Kentucky & $2,009(63.0)$ & $863(27.1)$ & $144(4.5)$ & $171(5.4)$ & $3,187(100.0)$ \\
\hline Michigan & $11,447(42.6)$ & $13,323(49.6)$ & $1,112(4.1)$ & $992(3.7)$ & $26,874(99.0)$ \\
\hline Minnesota & $4,928(53.7)$ & $2,237(24.4)$ & $1,390(15.1)$ & $628(6.8)$ & $9,183(93.1)$ \\
\hline Missouri & $2,182(47.1)$ & $2,001(43.2)$ & $325(7.0)$ & $125(2.7)$ & $4,633(97.2)$ \\
\hline Montana & $1,424(88.4)$ & $20(1.2)$ & $167(10.4)$ & $0(0.0)$ & $1,611(100.0)$ \\
\hline Nevada & $2,750(41.2)$ & $1,005(15.1)$ & $1,254(18.8)$ & $1,662(24.9)$ & 6,671 (93.7) \\
\hline New Jersey** & $6,798(31.3)$ & $6,908(31.8)$ & $3,806(17.5)$ & 4,208 (19.4) & $21,720(94.5)$ \\
\hline New York City ${ }^{\dagger \dagger}$ & $9,769(16.3)$ & $25,698(42.9)$ & $6,183(10.3)$ & $18,195(30.4)$ & $59,845(94.0)$ \\
\hline Ohio & $9,709(49.7)$ & $7,948(40.7)$ & $1,142(5.8)$ & $748(3.8)$ & $19,547(93.2)$ \\
\hline Oregon & $5,967(70.8)$ & $503(6.0)$ & $841(10.0)$ & $1,113(13.2)$ & $8,424(97.8)$ \\
\hline South Carolina & $2,986(51.8)$ & $2,306(40.0)$ & $184(3.2)$ & $294(5.1)$ & $5,770(99.9)$ \\
\hline South Dakota & $311(70.0)$ & $40(9.0)$ & $63(14.2)$ & $30(6.8)$ & $444(100.0)$ \\
\hline Tennessee & 4,939 (44.6) & $5,353(48.3)$ & $310(2.8)$ & $472(4.3)$ & $11,074(97.0)$ \\
\hline Texas $\S \S$ & $15,430(28.7)$ & $14,103(26.2)$ & $3,648(6.8)$ & $20,586(38.3)$ & $53,767(99.7)$ \\
\hline Utah & $2,020(65.1)$ & $110(3.5)$ & $274(8.8)$ & $697(22.5)$ & $3,101(97.6)$ \\
\hline Vermont & $1,102(89.4)$ & $26(2.1)$ & $76(6.2)$ & $28(2.3)$ & $1,232(97.4)$ \\
\hline Virginia & $6,946(39.0)$ & $7,978(44.8)$ & $1,987(11.1)$ & $916(5.1)$ & $17,827(95.5)$ \\
\hline West Virginia & $1,271(83.8)$ & $201(13.3)$ & $30(2.0)$ & $14(0.9)$ & $1,516(100.0)$ \\
\hline Total & $124,893(36.9)$ & $121,829(36.0)$ & $29,364(8.7)$ & $62,714(18.5)$ & $338,800(95.9)^{\text {ๆๆ }}$ \\
\hline Abortion rate $\mathrm{e}^{* * *}$ & 6.8 & 25.1 & 13.5 & 11.2 & 10.9 \\
\hline Abortion ratio ${ }^{\dagger+\dagger}$ & 111 & 390 & 222 & 147 & 170 \\
\hline
\end{tabular}

* Data from 30 reporting areas; excludes 22 reporting areas (California, Connecticut, Florida, Illinois, lowa, Louisiana, Maine, Maryland, Massachusetts, Mississippi, Nebraska, New Hampshire, New Mexico, New York State, North Carolina, North Dakota, Oklahoma, Pennsylvania, Rhode Island, Washington, Wisconsin, and Wyoming) that did not report, did not report by race/ethnicity, or did not meet reporting standards.

+ Percentages for the individual component categories might not add to 100 because of rounding.

$\S$ Percentage is calculated as the number of abortions reported by known race/ethnicity divided by the sum of abortions reported by known and unknown race/ethnicity.

I Because reporting is not mandatory, information could not be obtained for all abortions performed in the District of Columbia.

** Data from hospitals and licensed ambulatory care facilities only; because reporting is not mandatory for private physicians and women's centers, information could not be obtained for all abortions performed in New Jersey.

${ }^{+\dagger}$ Non-Hispanic categories include abortions for women whose ethnicity was reported as unknown; previous evaluation has shown that most reports without ethnicity are for non-Hispanic women.

$\S \S$ Reporting form contains only one question for race and ethnicity; therefore, abortions reported for women of white, black, and other races (Asian and Native American) are not explicitly identified as non-Hispanic.

१ी Percentage is based on a total of 353,128 abortions reported among the areas that met reporting standards for race/ethnicity.

*** Number of abortions obtained by women in a given race/ethnicity group per 1,000 women in that same racial/ethnic group. For each reporting area, abortions for women of unknown race/ethnicity were distributed according to the distribution of abortions among women of known race/ethnicity for that area.

${ }^{+t+}$ Number of abortions obtained by women in a given race/ethnicity group per 1,000 live births to women in that same race/ethnicity group. For each reporting area, abortions for women of unknown race/ethnicity were distributed according to the distribution of abortions among women of known race/ethnicity for that area. 
TABLE 13. Reported abortions, by known race of women who obtained an abortion and reporting area of occurrence - selected reporting areas,* United States, 2015

\begin{tabular}{|c|c|c|c|c|}
\hline \multirow[b]{3}{*}{ State/Area } & \multicolumn{3}{|c|}{ Race } & \multirow{2}{*}{$\begin{array}{c}\text { Total abortions reported } \\
\text { by known race }\end{array}$} \\
\hline & White & Black & Other & \\
\hline & No. $(\%)^{\dagger}$ & No. (\%) & No. (\%) & No. $(\% \text { all reported abortions })^{\S}$ \\
\hline Alabama & $2,146(36.4)$ & $3,536(60.0)$ & 212 (3.6) & $5,894(99.9)$ \\
\hline Alaska & $810(62.2)$ & $102(7.8)$ & $390(30.0)$ & $1,302(97.6)$ \\
\hline Arkansas & 1,691 (49.3) & $1,734(50.6)$ & $5(0.1)$ & $3,430(91.0)$ \\
\hline Colorado & $6,272(67.2)$ & 799 (8.6) & $2,267(24.3)$ & $9,338(92.3)$ \\
\hline Delaware & $1,411(50.7)$ & $1,200(43.1)$ & $174(6.2)$ & $2,785(100.0)$ \\
\hline District of Columbia" & $226(18.8)$ & $913(75.9)$ & $64(5.3)$ & 1,203 (94.9) \\
\hline Georgia & $7,726(27.7)$ & $18,450(66.2)$ & $1,688(6.1)$ & $27,864(89.9)$ \\
\hline Hawaii & $526(27.6)$ & $84(4.4)$ & $1,294(68.0)$ & $1,904(94.0)$ \\
\hline Idaho & 1,041 (89.4) & $28(2.4)$ & $95(8.2)$ & $1,164(91.5)$ \\
\hline Indiana & $4,545(57.1)$ & $2,396(30.1)$ & $1,016(12.8)$ & 7,957 (100.0) \\
\hline lowa & 2,865 (71.9) & $608(15.3)$ & $510(12.8)$ & $3,983(99.8)$ \\
\hline Kansas & 4,079 (59.7) & $1,514(22.2)$ & $1,234(18.1)$ & 6,827 (98.5) \\
\hline Louisiana & 2,753 (29.6) & $5,763(62.1)$ & $771(8.3)$ & $9,287(99.2)$ \\
\hline Maine & $1,582(86.3)$ & $103(5.6)$ & $149(8.1)$ & $1,834(99.9)$ \\
\hline Massachusetts & $8,573(50.0)$ & $2,973(17.3)$ & $5,613(32.7)$ & $17,159(92.4)$ \\
\hline Michigan & $12,086(45.4)$ & $13,380(50.2)$ & $1,184(4.4)$ & $26,650(98.2)$ \\
\hline Minnesota & $5,283(55.2)$ & $2,413(25.2)$ & $1,883(19.7)$ & $9,579(97.1)$ \\
\hline Mississippi & $527(20.3)$ & $2,020(77.6)$ & $55(2.1)$ & 2,602 (99.6) \\
\hline Missouri & 2,263 (48.8) & $2,016(43.5)$ & $360(7.8)$ & 4,639 (97.4) \\
\hline Montana & 1,424 (88.4) & $20(1.2)$ & $167(10.4)$ & 1,611(100.0) \\
\hline Nebraska & 1,282 (66.6) & $352(18.3)$ & $291(15.1)$ & 1,925 (96.1) \\
\hline New Jersey** & $8,868(40.0)$ & $9,041(40.7)$ & 4,282 (19.3) & $22,191(96.5)$ \\
\hline North Carolina & 9,854 (39.6) & $13,695(55.1)$ & $1,314(5.3)$ & $24,863(90.0)$ \\
\hline North Dakota & 805 (69.7) & $142(12.3)$ & $208(18.0)$ & 1,155 (99.1) \\
\hline Ohio & $10,338(51.5)$ & $8,421(42.0)$ & $1,298(6.5)$ & 20,057 (95.6) \\
\hline Oklahoma & 2,876 (61.1) & $914(19.4)$ & $917(19.5)$ & 4,707 (100.0) \\
\hline Oregon & 6,588 (79.9) & $542(6.6)$ & $1,111(13.5)$ & 8,241 (95.7) \\
\hline Pennsylvania & $15,820(50.2)$ & $13,332(42.3)$ & $2,366(7.5)$ & $31,518(99.1)$ \\
\hline Rhode Island & 1,918 (76.8) & $419(16.8)$ & $159(6.4)$ & 2,496 (94.2) \\
\hline South Carolina & 3,271 (56.7) & $2,315(40.1)$ & $187(3.2)$ & 5,773 (99.9) \\
\hline South Dakota & 340 (76.6) & $40(9.0)$ & 64 (14.4) & $444(100.0)$ \\
\hline Tennessee & $5,345(48.3)$ & $5,361(48.5)$ & $353(3.2)$ & 11,059 (96.9) \\
\hline Utah & 2,321 (82.9) & $119(4.3)$ & $359(12.8)$ & 2,799 (88.1) \\
\hline Vermont & $1,124(90.4)$ & $30(2.4)$ & $89(7.2)$ & $1,243(98.3)$ \\
\hline Virginia & 7,623 (41.4) & $8,248(44.8)$ & 2,532 (13.8) & 18,403 (98.6) \\
\hline West Virginia & 1,281 (84.5) & 205 (13.5) & $30(2.0)$ & 1,516 (100.0) \\
\hline Wisconsin $^{\dagger+}$ & $3,426(65.7)$ & $1,436(27.5)$ & $352(6.8)$ & $5,214(95.5)$ \\
\hline Total & $150,909(48.6)$ & $124,664(40.1)$ & $35,043(11.3)$ & $310,616(95.8)^{\S \S}$ \\
\hline Abortion Rate qף $^{\text {II }}$ & 6.4 & 23.0 & 16.5 & 9.9 \\
\hline Abortion Ratio*** & 103 & 347 & 276 & 159 \\
\hline
\end{tabular}

* Data from 37 reporting areas; excludes 15 areas (Arizona, California, Connecticut, Florida, Illinois, Kentucky, Maryland, Nevada, New Hampshire, New Mexico, New York State, New York City, Texas, Washington, and Wyoming) that did not report, did not report by race, or did not meet reporting standards.

† Percentages for the individual component categories might not add to 100 because of rounding.

$\S$ Percentage is calculated as the number of abortions reported by known race, divided by the sum of abortions reported by known and unknown race.

" Because reporting is not mandatory, information could not be obtained for all abortions performed in the District of Columbia.

** Data from hospitals and licensed ambulatory care facilities only; because reporting is not mandatory for private physicians and women's centers, information could not be obtained for all abortions performed in New Jersey.

${ }^{+\dagger}$ Includes residents only.

$\S \S$ Percentage is based on a total of 324,391 abortions reported among the areas that met reporting standards for race.

กा Number of abortions obtained by women in a given racial group per 1,000 women in that same racial group. For each reporting area, abortions for women of unknown race were distributed according to the distribution of abortions among women of known race for that area.

*** Number of abortions obtained by women in a given racial group per 1,000 live births to women in that same racial group. For each reporting area, abortions for women of unknown race were distributed according to the distribution of abortions among women of known race for that area. 
TABLE 14. Reported abortions, by known ethnicity of women who obtained an abortion and reporting area of occurrence - selected reporting areas, * United States, 2015

\begin{tabular}{|c|c|c|c|}
\hline \multirow[b]{3}{*}{ State/Area } & \multicolumn{2}{|c|}{ Ethnicity } & \multirow{2}{*}{$\begin{array}{c}\text { Total abortions reported by } \\
\text { known ethnicity }\end{array}$} \\
\hline & Hispanic & Non-Hispanic & \\
\hline & No. $(\%)^{\dagger}$ & No. (\%) & No. $(\% \text { of all reported abortions })^{\S}$ \\
\hline Alabama & $302(5.1)$ & $5,583(94.9)$ & 5,885 (99.8) \\
\hline Alaska & $27(2.3)$ & $1,168(97.7)$ & 1,195 (89.6) \\
\hline Arizona & $4,437(35.1)$ & $8,218(64.9)$ & $12,655(100.0)$ \\
\hline Arkansas & $221(5.9)$ & $3,538(94.1)$ & 3,759 (99.7) \\
\hline Colorado & $2,349(26.2)$ & 6,602 (73.8) & $8,951(88.5)$ \\
\hline Delaware & $282(10.1)$ & 2,498 (89.9) & 2,780 (99.8) \\
\hline District of Columbia" & $98(8.0)$ & $1,128(92.0)$ & $1,226(96.8)$ \\
\hline Georgia & $2,179(7.2)$ & $28,097(92.8)$ & $30,276(97.6)$ \\
\hline Hawaii & $213(11.2)$ & 1,688 (88.8) & 1,901 (93.8) \\
\hline Idaho & $184(15.8)$ & $984(84.2)$ & $1,168(91.8)$ \\
\hline Indiana & $644(8.1)$ & $7,313(91.9)$ & $7,957(100.0)$ \\
\hline Kansas & $899(13.0)$ & $6,032(87.0)$ & $6,931(100.0)$ \\
\hline Kentucky & $171(5.4)$ & $3,017(94.6)$ & $3,188(100.0)$ \\
\hline Michigan & $992(3.7)$ & $26,071(96.3)$ & $27,063(99.7)$ \\
\hline Minnesota & $628(6.8)$ & 8,597 (93.2) & $9,225(93.6)$ \\
\hline Missouri & $125(2.6)$ & $4,617(97.4)$ & $4,742(99.5)$ \\
\hline Montana & $0(0.0)$ & $1,611(100.0)$ & $1,611(100.0)$ \\
\hline Nevada & $1,662(24.2)$ & $5,194(75.8)$ & $6,856(96.3)$ \\
\hline New Jersey** & $4,208(19.3)$ & $17,606(80.7)$ & $21,814(94.9)$ \\
\hline New Mexico & $2,192(55.2)$ & $1,779(44.8)$ & 3,971 (85.1) \\
\hline New York & 22,295 (23.9) & $70,801(76.1)$ & $93,096(100.0)$ \\
\hline New York City ${ }^{\dagger \dagger}$ & 18,195 (28.6) & $45,451(71.4)$ & $63,646(100.0)$ \\
\hline New York State & $4,100(13.9)$ & $25,350(86.1)$ & $29,450(100.0)$ \\
\hline Ohio & 748 (3.8) & $19,057(96.2)$ & $19,805(94.4)$ \\
\hline Oregon & $1,113(12.9)$ & 7,497 (87.1) & $8,610(100.0)$ \\
\hline Pennsylvania & $3,050(9.7)$ & $28,505(90.3)$ & 31,555 (99.2) \\
\hline South Carolina & $294(5.1)$ & $5,480(94.9)$ & $5,774(99.9)$ \\
\hline South Dakota & $30(6.8)$ & $414(93.2)$ & $444(100.0)$ \\
\hline Tennessee & $472(4.2)$ & $10,734(95.8)$ & $11,206(98.2)$ \\
\hline Texas $^{\dagger \dagger}$ & $20,586(38.3)$ & $33,181(61.7)$ & $53,767(99.7)$ \\
\hline Utah & $697(22.2)$ & 2,436 (77.8) & $3,133(98.6)$ \\
\hline Vermont & $28(2.3)$ & $1,216(97.7)$ & $1,244(98.3)$ \\
\hline Virginia & $916(5.1)$ & $17,030(94.9)$ & $17,946(96.2)$ \\
\hline West Virginia & $14(0.9)$ & 1,502 (99.1) & $1,516(100.0)$ \\
\hline Total & $72,056(17.5)$ & $339,194(82.5)$ & $411,250(98.1)^{\S \S}$ \\
\hline Abortion rate & 11.2 & 11.3 & 11.3 \\
\hline Abortion ratio*** & 148 & 184 & 177 \\
\hline
\end{tabular}

* Data from 33 reporting areas; excludes 19 areas (California, Connecticut, Florida, Illinois, lowa, Louisiana, Maine, Maryland, Massachusetts, Mississippi, Nebraska, New Hampshire, North Carolina, North Dakota, Oklahoma, Rhode Island, Washington, Wisconsin, and Wyoming) that did not report, did not report by ethnicity, or did not meet reporting standards.

† Percentages for the individual component categories might not add to 100 because of rounding.

$\S$ Percentage is calculated as the number of abortions reported by known ethnicity divided by the sum of abortions reported by known and unknown ethnicity.

" Because reporting is not mandatory, information could not be obtained for all abortions performed in the District of Columbia.

** Data from hospitals and licensed ambulatory care facilities only; because reporting is not mandatory for private physicians and women's centers, information could not be obtained for all abortions performed in New Jersey.

${ }^{\dagger+}$ Non-Hispanic category includes abortions for women whose ethnicity was reported as unknown; previous evaluation has shown that most reports without ethnicity are for non-Hispanic women.

$\S \S$ Percentage is based on a total of 419,065 abortions reported among the areas that met reporting standards for ethnicity.

१ศ Number of abortions obtained by women in a given ethnic group per 1,000 women in that same ethnic group. For each reporting area, abortions for women of unknown ethnicity were distributed according to the distribution of abortions among women of known ethnicity for that area.

*** Number of abortions obtained by women in a given ethnic group per 1,000 live births to women in that same ethnic group. For each reporting area, abortions for women of unknown ethnicity were distributed according to the distribution of abortions among women of known ethnicity for that area. 
TABLE 15. Reported abortions, by known marital status and reporting area of occurrence - selected reporting areas,* United States, 2015

\begin{tabular}{|c|c|c|c|}
\hline \multirow[b]{3}{*}{ State/Area } & \multicolumn{2}{|c|}{ Marital status } & \multirow{2}{*}{$\begin{array}{l}\text { Total abortions reported by } \\
\text { known marital status }\end{array}$} \\
\hline & Married & Unmarried & \\
\hline & No. $(\%)^{\dagger}$ & No. (\%) & No. $(\% \text { of all reported abortions })^{\S}$ \\
\hline Alabama & $643(10.9)$ & $5,231(89.1)$ & $5,874(99.6)$ \\
\hline Alaska & $247(18.7)$ & $1,075(81.3)$ & $1,322(99.1)$ \\
\hline Arkansas & $528(14.0)$ & $3,234(86.0)$ & $3,762(99.8)$ \\
\hline Colorado & $1,778(18.4)$ & $7,865(81.6)$ & $9,643(95.3)$ \\
\hline Delaware & $332(11.9)$ & $2,453(88.1)$ & $2,785(100.0)$ \\
\hline Georgia & $4,143(13.8)$ & $25,897(86.2)$ & $30,040(96.9)$ \\
\hline Hawaii & $546(27.2)$ & $1,464(72.8)$ & $2,010(99.2)$ \\
\hline Idaho & $231(18.8)$ & $997(81.2)$ & $1,228(96.5)$ \\
\hline Illinois & $4,017(11.8)$ & $30,151(88.2)$ & $34,168(85.7)$ \\
\hline Indiana & $986(12.4)$ & 6,969 (87.6) & $7,955(100.0)$ \\
\hline lowa & $578(14.5)$ & $3,411(85.5)$ & $3,989(100.0)$ \\
\hline Kansas & $1,063(15.4)$ & $5,828(84.6)$ & $6,891(99.4)$ \\
\hline Kentucky & $511(16.0)$ & $2,677(84.0)$ & $3,188(100.0)$ \\
\hline Louisiana & $1,025(11.2)$ & $8,113(88.8)$ & $9,138(97.6)$ \\
\hline Maine & $262(14.6)$ & $1,529(85.4)$ & $1,791(97.5)$ \\
\hline Massachusetts & $2,440(15.0)$ & $13,834(85.0)$ & $16,274(87.6)$ \\
\hline Michigan & $2,910(10.7)$ & $24,234(89.3)$ & $27,144(100.0)$ \\
\hline Minnesota & $1,472(16.2)$ & $7,640(83.8)$ & $9,112(92.4)$ \\
\hline Mississippi & $229(9.2)$ & $2,263(90.8)$ & $2,492(95.4)$ \\
\hline Missouri & $722(15.4)$ & 3,959 (84.6) & $4,681(98.2)$ \\
\hline Montana & $232(14.4)$ & 1,379 (85.6) & $1,611(100.0)$ \\
\hline Nebraska & $258(13.1)$ & $1,714(86.9)$ & $1,972(98.4)$ \\
\hline Nevada & $1,048(16.2)$ & $5,419(83.8)$ & 6,467 (90.9) \\
\hline New Jersey & $2,860(12.6)$ & $19,815(87.4)$ & 22,675 (98.6) \\
\hline New Mexico & $675(15.3)$ & $3,749(84.7)$ & $4,424(94.8)$ \\
\hline New York City & $8,846(15.9)$ & $46,849(84.1)$ & $55,695(87.5)$ \\
\hline North Dakota & $190(16.3)$ & $975(83.7)$ & 1,165 (99.9) \\
\hline Oklahoma & $892(18.9)$ & $3,816(81.1)$ & $4,708(100.0)$ \\
\hline Oregon & $1,440(19.0)$ & $6,143(81.0)$ & 7,583 (88.1) \\
\hline Pennsylvania & $3,851(12.1)$ & $27,923(87.9)$ & 31,774 (99.9) \\
\hline South Carolina & $407(7.0)$ & $5,368(93.0)$ & 5,775 (99.9) \\
\hline South Dakota & $83(18.7)$ & $361(81.3)$ & $444(100.0)$ \\
\hline Tennessee & $1,312(11.8)$ & $9,795(88.2)$ & $11,107(97.3)$ \\
\hline Texas & $9,139(16.9)$ & $44,781(83.1)$ & $53,920(100.0)$ \\
\hline Utah & $793(25.3)$ & $2,339(74.7)$ & $3,132(98.6)$ \\
\hline Vermont & $234(19.5)$ & $966(80.5)$ & $1,200(94.9)$ \\
\hline Virginia & $2,670(14.3)$ & $15,993(85.7)$ & $18,663(100.0)$ \\
\hline West Virginia & $256(17.0)$ & $1,250(83.0)$ & $1,506(99.3)$ \\
\hline Wisconsin & $667(11.8)$ & $4,983(88.2)$ & $5,650(99.8)$ \\
\hline Total & $60,516(14.3)$ & $362,442(85.7)$ & $422,958(95.2)^{* *}$ \\
\hline Abortion ratio ${ }^{\dagger \dagger}$ & 41 & 373 & 174 \\
\hline
\end{tabular}

* Data from 39 reporting areas; excludes 13 areas (Arizona, California, Connecticut, District of Columbia, Florida, Maryland, New Hampshire, New York State, North Carolina, Ohio, Rhode Island, Washington, and Wyoming) that did not report, did not report by marital status, or did not meet reporting standards.

† Percentages for the individual component categories might not add to 100 because of rounding.

$\S$ Percentage is calculated as the number of abortions reported by known marital status divided by the sum of abortions reported by known and unknown marital status.

" Data from hospitals and licensed ambulatory care facilities only; because reporting is not mandatory for private physicians and women's centers, information could not be obtained for all abortions performed in New Jersey.

** Percentage is based on a total of 444,482 abortions reported among the areas that met reporting standards for marital status.

${ }^{++}$Number of abortions obtained by women by marital status per 1,000 live births to women of the same marital status. For each reporting area, abortions for women of unknown marital status were distributed according to the distribution of abortions among women of known marital status for that area. 
TABLE 16. Reported abortions, by known number of previous live births and reporting area of occurrence - selected reporting areas, ${ }^{*}$ United States, 2015

\begin{tabular}{|c|c|c|c|c|c|c|}
\hline \multirow[b]{3}{*}{ State/Area } & \multicolumn{5}{|c|}{ No. of previous live births } & \multirow{3}{*}{$\begin{array}{c}\begin{array}{c}\text { Total abortions reported } \\
\text { by known number of } \\
\text { previous live births }\end{array} \\
\begin{array}{c}\text { No. }(\% \text { of all } \\
\text { reported abortions) }\end{array}\end{array}$} \\
\hline & 0 & 1 & 2 & 3 & $\geq 4$ & \\
\hline & No. $(\%)^{\dagger}$ & No. (\%) & No. (\%) & No. (\%) & No. (\%) & \\
\hline Alabama & $2,198(37.3)$ & $1,658(28.1)$ & $1,232(20.9)$ & $523(8.9)$ & $286(4.8)$ & $5,897(100.0)$ \\
\hline Alaska & $597(45.4)$ & $292(22.2)$ & $217(16.5)$ & 103 (7.8) & 107 (8.1) & 1,316 (98.7) \\
\hline Arizona & $5,358(42.4)$ & $2,928(23.2)$ & 2,391 (18.9) & $1,141(9.0)$ & $811(6.4)$ & 12,629 (99.8) \\
\hline Arkansas & $1,251(33.2)$ & $1,110(29.5)$ & $805(21.4)$ & $393(10.4)$ & $209(5.5)$ & 3,768 (99.9) \\
\hline Colorado & $5,362(53.7)$ & $1,946(19.5)$ & $1,551(15.5)$ & $728(7.3)$ & $405(4.1)$ & 9,992 (98.8) \\
\hline Delaware & $1,098(39.4)$ & 752 (27.0) & $548(19.7)$ & $234(8.4)$ & $153(5.5)$ & $2,785(100.0)$ \\
\hline Georgia & 12,275 (39.8) & $7,769(25.2)$ & 6,073 (19.7) & $2,824(9.2)$ & $1,875(6.1)$ & 30,816 (99.4) \\
\hline Idaho & $582(45.8)$ & $292(23.0)$ & $218(17.2)$ & 107 (8.4) & $71(5.6)$ & $1,270(99.8)$ \\
\hline Indiana & $2,943(37.0)$ & $2,067(26.0)$ & $1,693(21.3)$ & 783 (9.8) & 471 (5.9) & $7,957(100.0)$ \\
\hline lowa & $1,694(42.5)$ & 901 (22.6) & 781 (19.6) & $382(9.6)$ & $231(5.8)$ & $3,989(100.0)$ \\
\hline Kansas & $2,733(39.4)$ & $1,720(24.8)$ & $1,396(20.1)$ & $735(10.6)$ & $347(5.0)$ & $6,931(100.0)$ \\
\hline Kentucky & $1,254(39.3)$ & 894 (28.0) & 625 (19.6) & $287(9.0)$ & $128(4.0)$ & $3,188(100.0)$ \\
\hline Louisiana & $3,037(32.5)$ & $2,639(28.2)$ & $2,216(23.7)$ & $941(10.1)$ & 525 (5.6) & $9,358(100.0)$ \\
\hline Maine & $928(50.6)$ & 405 (22.1) & $321(17.5)$ & $119(6.5)$ & $62(3.4)$ & 1,835 (99.9) \\
\hline Massachusetts & $7,496(47.3)$ & $3,821(24.1)$ & 2,835 (17.9) & $1,131(7.1)$ & $552(3.5)$ & $15,835(85.3)$ \\
\hline Michigan? & $9,641(35.5)$ & $7,420(27.3)$ & $5,675(20.9)$ & $2,603(9.6)$ & $1,804(6.6)$ & $27,143(100.0)$ \\
\hline Minnesota & $3,942(40.0)$ & $2,305(23.4)$ & 2,035 (20.6) & $901(9.1)$ & $678(6.9)$ & 9,861 (100.0) \\
\hline Mississippi & $802(30.7)$ & $759(29.0)$ & $623(23.8)$ & $282(10.8)$ & 147 (5.6) & $2,613(100.0)$ \\
\hline Missouri & $1,833(38.8)$ & $1,267(26.8)$ & $924(19.5)$ & $457(9.7)$ & $247(5.2)$ & $4,728(99.2)$ \\
\hline Montana & $820(50.9)$ & 355 (22.0) & $249(15.5)$ & $126(7.8)$ & 61 (3.8) & $1,611(100.0)$ \\
\hline Nebraska & $768(38.4)$ & 432 (21.6) & $422(21.1)$ & 238 (11.9) & $142(7.1)$ & 2,002 (99.9) \\
\hline Nevada & $3,026(42.5)$ & $1,621(22.8)$ & $1,357(19.1)$ & $672(9.4)$ & $438(6.2)$ & $7,114(100.0)$ \\
\hline New Jersey** & $9,521(41.5)$ & $6,409(27.9)$ & 4,049 (17.6) & $1,802(7.8)$ & $1,187(5.2)$ & 22,968 (99.9) \\
\hline New Mexico & 1,651 (38.8) & $1,098(25.8)$ & 804 (18.9) & $403(9.5)$ & $300(7.0)$ & $4,256(91.2)$ \\
\hline New York City & $26,608(44.0)$ & $15,469(25.6)$ & $11,186(18.5)$ & $4,500(7.4)$ & $2,672(4.4)$ & $60,435(95.0)$ \\
\hline North Dakota & $473(40.6)$ & 275 (23.6) & $229(19.6)$ & 111 (9.5) & $78(6.7)$ & $1,166(100.0)$ \\
\hline Ohio & $7,694(36.9)$ & $5,532(26.6)$ & $4,308(20.7)$ & $2,028(9.7)$ & $1,264(6.1)$ & $20,826(99.3)$ \\
\hline Oklahoma & $1,891(40.2)$ & $1,198(25.5)$ & $950(20.2)$ & $427(9.1)$ & $239(5.1)$ & 4,705 (99.9) \\
\hline Oregon & 4,202 (49.4) & $1,893(22.3)$ & $1,415(16.6)$ & $625(7.4)$ & $367(4.3)$ & 8,502 (98.7) \\
\hline Pennsylvania & $12,330(38.8)$ & $8,592(27.0)$ & 6,466 (20.3) & $2,800(8.8)$ & $1,630(5.1)$ & $31,818(100.0)$ \\
\hline Rhode Island & $1,175(45.0)$ & 666 (25.5) & $478(18.3)$ & 204 (7.8) & $91(3.5)$ & $2,614(98.7)$ \\
\hline South Carolina & $2,444(42.3)$ & $1,491(25.8)$ & 1,172 (20.3) & $435(7.5)$ & $236(4.1)$ & $5,778(100.0)$ \\
\hline South Dakota & $168(37.8)$ & $105(23.6)$ & $97(21.8)$ & $51(11.5)$ & $23(5.2)$ & $444(100.0)$ \\
\hline Tennessee & $3,855(35.2)$ & $2,744(25.0)$ & 2,282 (20.8) & $1,229(11.2)$ & 847 (7.7) & $10,957(96.0)$ \\
\hline Texas & 20,457 (37.9) & $13,495(25.0)$ & $11,427(21.2)$ & $5,376(10.0)$ & $3,179(5.9)$ & $53,934(100.0)$ \\
\hline Utah & $1,605(51.0)$ & 595 (18.9) & $529(16.8)$ & $255(8.1)$ & $162(5.1)$ & $3,146(99.1)$ \\
\hline Vermont & $627(50.2)$ & $272(21.8)$ & 224 (17.9) & $88(7.0)$ & $38(3.0)$ & 1,249 (98.7) \\
\hline Virginia & $7,460(40.0)$ & 4,832 (25.9) & $3,889(20.8)$ & 1,596 (8.6) & $886(4.7)$ & $18,663(100.0)$ \\
\hline Washington & $7,988(46.7)$ & $3,899(22.8)$ & $3,084(18.0)$ & $1,328(7.8)$ & 790 (4.6) & 17,089 (99.9) \\
\hline West Virginia & $436(28.8)$ & 472 (31.1) & $356(23.5)$ & $183(12.1)$ & $69(4.6)$ & 1,516 (100.0) \\
\hline Total & $180,223(40.7)$ & $112,390(25.4)$ & $87,132(19.7)$ & $39,151(8.8)$ & $23,808(5.4)$ & $442,704(98.3)^{\dagger \dagger}$ \\
\hline
\end{tabular}

* Data from 40 reporting areas; excludes 12 areas (California, Connecticut, District of Columbia, Florida, Hawaii, Illinois, Maryland, New Hampshire, New York State, North Carolina, Wisconsin, and Wyoming) that did not report, did not report by number of previous births, or did not meet reporting standards.

† Percentages for the individual component categories might not add to 100 because of rounding.

$\S$ Percentage is calculated as the number of abortions reported by known number of previous live births, divided by the sum of abortions reported by known and unknown number of previous live births.

I Recorded as the number of previous pregnancies carried to term.

** Data from hospitals and licensed ambulatory care facilities only; because reporting is not mandatory for private physicians and women's centers, information could not be obtained for all abortions performed in New Jersey.

t+ Percentage is based on a total of 450,318 abortions reported among the areas that met reporting standards for the number of previous births. 
TABLE 17. Reported abortions, by known number of previous induced abortions and reporting area of occurrence - selected reporting areas,* United States, 2015

\begin{tabular}{|c|c|c|c|c|c|}
\hline \multirow[b]{3}{*}{ State/Area } & \multicolumn{4}{|c|}{ Number of previous induced abortions } & \multirow{2}{*}{$\begin{array}{c}\text { Total abortions reported by } \\
\text { known no. of previous } \\
\text { induced abortions }\end{array}$} \\
\hline & 0 & 1 & 2 & $\geq 3$ & \\
\hline & No. $(\%)^{\dagger}$ & No. (\%) & No. (\%) & No. (\%) & $\begin{array}{l}\text { No. }(\% \text { of all } \\
\text { reported abortions) }\end{array}$ \\
\hline Alabama & $3,890(66.0)$ & $1,440(24.4)$ & $401(6.8)$ & $166(2.8)$ & $5,897(100.0)$ \\
\hline Alaska & $886(66.6)$ & $291(21.9)$ & $100(7.5)$ & $54(4.1)$ & $1,331(99.8)$ \\
\hline Arizona & $7,958(63.3)$ & $3,063(24.4)$ & $1,033(8.2)$ & $513(4.1)$ & $12,567(99.3)$ \\
\hline Arkansas & $2,219(58.9)$ & $845(22.4)$ & $360(9.6)$ & $344(9.1)$ & $3,768(99.9)$ \\
\hline Colorado & $6,561(65.4)$ & $2,409(24.0)$ & $743(7.4)$ & $312(3.1)$ & $10,025(99.1)$ \\
\hline Delaware & $1,633(58.6)$ & $668(24.0)$ & $290(10.4)$ & $194(7.0)$ & $2,785(100.0)$ \\
\hline Georgia & $19,033(61.7)$ & $7,327(23.7)$ & $2,957(9.6)$ & $1,547(5.0)$ & $30,864(99.5)$ \\
\hline Idaho & 932 (73.4) & $252(19.9)$ & 59 (4.6) & $26(2.0)$ & $1,269(99.8)$ \\
\hline Indiana & $5,087(63.9)$ & $1,943(24.4)$ & $635(8.0)$ & $292(3.7)$ & $7,957(100.0)$ \\
\hline lowa & $2,550(64.0)$ & $964(24.2)$ & $306(7.7)$ & $163(4.1)$ & $3,983(99.8)$ \\
\hline Kansas & $4,489(64.8)$ & $1,613(23.3)$ & 547 (7.9) & $282(4.1)$ & $6,931(100.0)$ \\
\hline Kentucky & $2,032(65.3)$ & $733(23.6)$ & $258(8.3)$ & $88(2.8)$ & $3,111(97.6)$ \\
\hline Louisiana & $5,616(60.0)$ & $2,509(26.8)$ & $851(9.1)$ & $382(4.1)$ & $9,358(100.0)$ \\
\hline Maine & $1,186(65.4)$ & $443(24.4)$ & $136(7.5)$ & $49(2.7)$ & $1,814(98.8)$ \\
\hline Massachusetts & $9,231(52.6)$ & $4,575(26.1)$ & $2,082(11.9)$ & $1,673(9.5)$ & $17,561(94.6)$ \\
\hline Michigan & $13,637(50.2)$ & $6,884(25.4)$ & $3,789(14.0)$ & $2,837(10.5)$ & $27,147(100.0)$ \\
\hline Minnesota & $5,902(59.9)$ & $2,308(23.4)$ & $948(9.6)$ & $703(7.1)$ & $9,861(100.0)$ \\
\hline Mississippi & $1,709(65.4)$ & $600(23.0)$ & $223(8.5)$ & $81(3.1)$ & $2,613(100.0)$ \\
\hline Missouri & $2,996(62.9)$ & $1,170(24.6)$ & $428(9.0)$ & $170(3.6)$ & $4,764(100.0)$ \\
\hline Montana & $563(34.9)$ & $716(44.4)$ & $221(13.7)$ & $111(6.9)$ & $1,611(100.0)$ \\
\hline Nebraska & $1,250(62.4)$ & $503(25.1)$ & $182(9.1)$ & 69 (3.4) & $2,004(100.0)$ \\
\hline Nevada & $3,853(54.1)$ & $1,890(26.6)$ & $767(10.8)$ & $606(8.5)$ & $7,116(100.0)$ \\
\hline New Jersey & $15,297(66.6)$ & 3,889 (16.9) & $1,914(8.3)$ & $1,870(8.1)$ & $22,970(99.9)$ \\
\hline New York City & $23,240(38.9)$ & $13,775(23.0)$ & $11,021(18.4)$ & $11,730(19.6)$ & $59,766(93.9)$ \\
\hline North Dakota & $753(64.6)$ & $273(23.4)$ & $85(7.3)$ & $55(4.7)$ & $1,166(100.0)$ \\
\hline Ohio & $12,073(58.2)$ & $5,427(26.2)$ & $2,042(9.8)$ & $1,193(5.8)$ & 20,735 (98.9) \\
\hline Oklahoma & $3,143(66.8)$ & $1,053(22.4)$ & $325(6.9)$ & 181 (3.8) & $4,702(99.9)$ \\
\hline Oregon & 5,049 (59.3) & $2,077(24.4)$ & 844 (9.9) & $547(6.4)$ & 8,517 (98.9) \\
\hline Pennsylvania & $16,826(52.9)$ & $8,041(25.3)$ & $3,889(12.2)$ & $3,062(9.6)$ & $31,818(100.0)$ \\
\hline Rhode Island & $1,392(54.3)$ & $691(27.0)$ & $262(10.2)$ & $218(8.5)$ & $2,563(96.8)$ \\
\hline South Carolina & $3,273(56.6)$ & $1,381(23.9)$ & 661 (11.4) & $463(8.0)$ & $5,778(100.0)$ \\
\hline South Dakota & $300(67.6)$ & $88(19.8)$ & $31(7.0)$ & $25(5.6)$ & $444(100.0)$ \\
\hline Tennessee & $5,837(53.2)$ & $2,921(26.6)$ & $1,319(12.0)$ & $903(8.2)$ & $10,980(96.2)$ \\
\hline Texas & $32,524(60.3)$ & $14,031(26.0)$ & $4,932(9.1)$ & $2,438(4.5)$ & $53,925(100.0)$ \\
\hline Utah & $2,467(77.7)$ & 504 (15.9) & 115 (3.6) & $90(2.8)$ & $3,176(100.0)$ \\
\hline Vermont & $772(61.4)$ & $294(23.4)$ & $123(9.8)$ & $68(5.4)$ & $1,257(99.4)$ \\
\hline Virginia & $10,697(57.3)$ & $4,681(25.1)$ & $2,066(11.1)$ & $1,219(6.5)$ & $18,663(100.0)$ \\
\hline Washington & $9,766(57.2)$ & $4,102(24.0)$ & $1,809(10.6)$ & $1,406(8.2)$ & 17,083 (99.9) \\
\hline West Virginia & $781(51.5)$ & $426(28.1)$ & $190(12.5)$ & 119 (7.8) & $1,516(100.0)$ \\
\hline Total & $247,403(56.3)$ & $106,800(24.3)$ & $48,944(11.1)$ & $36,249(8.2)$ & $439,396(98.6)^{* *}$ \\
\hline
\end{tabular}

* Data from 39 reporting areas; excludes 13 areas (California, Connecticut, District of Columbia, Florida, Hawaii, Illinois, Maryland, New Hampshire, New Mexico, New York State, North Carolina, Wisconsin, and Wyoming) that did not report, did not report by the number of previous induced abortions, or did not meet reporting standards.

† Percentages for the individual component categories might not add to 100 because of rounding.

$\S$ Percentage is calculated as the number of abortions reported by known number of previous induced abortions divided by the sum of abortions reported by known and unknown number of previous induced abortions.

I Data from hospitals and licensed ambulatory care facilities only; because reporting is not mandatory for private physicians and women's centers, information could not be obtained for all abortions performed in New Jersey.

** Percentage is based on a total of 445,649 abortions reported among the areas that met reporting standards for the number of previous abortions. 
TABLE 18. Reported abortions, by known race, age group, and marital status of women who obtained an abortion — selected reporting areas, United States, 2015

\begin{tabular}{|c|c|c|c|c|}
\hline \multirow[b]{3}{*}{ Characteristic } & \multicolumn{3}{|c|}{ Race } & \multirow[b]{2}{*}{ Total } \\
\hline & White & Black & Other & \\
\hline & No. $(\%)^{*}$ & No. (\%) & No. (\%) & No. (\%) \\
\hline \multicolumn{5}{|c|}{ Age group (yrs) ${ }^{\dagger}$} \\
\hline$<15$ & $277(0.2)$ & $350(0.3)$ & $65(0.2)$ & $692(0.3)$ \\
\hline $15-19$ & $12,337(10.1)$ & $10,011(9.4)$ & $2,421(9.1)$ & $24,769(9.7)$ \\
\hline 15 & $617(0.5)$ & $654(0.6)$ & $113(0.4)$ & $1,384(0.5)$ \\
\hline 16 & $1,061(0.9)$ & $1,041(1.0)$ & $239(0.9)$ & $2,341(0.9)$ \\
\hline 17 & $1,824(1.5)$ & $1,542(1.5)$ & $352(1.3)$ & $3,718(1.5)$ \\
\hline 18 & $3,699(3.0)$ & $2,828(2.7)$ & $707(2.7)$ & $7,234(2.8)$ \\
\hline 19 & $5,136(4.2)$ & $3,946(3.7)$ & $1,010(3.8)$ & $10,092(4.0)$ \\
\hline $20-24$ & 38,349 (31.3) & $35,152(33.1)$ & $7,671(28.8)$ & $81,172(31.8)$ \\
\hline $25-29$ & $32,849(26.8)$ & $30,939(29.1)$ & $6,923(26.0)$ & $70,711(27.7)$ \\
\hline $30-34$ & $21,404(17.5)$ & $17,936(16.9)$ & $5,013(18.9)$ & $44,353(17.4)$ \\
\hline $35-39$ & $12,607(10.3)$ & $9,256(8.7)$ & $3,182(12.0)$ & $25,045(9.8)$ \\
\hline$\geq 40$ & 4,695 (3.8) & $2,596(2.4)$ & $1,315(4.9)$ & $8,606(3.4)$ \\
\hline Total & $122,518(100.0)$ & $106,240(100.0)$ & $26,590(100.0)$ & $255,348(100.0)$ \\
\hline \multicolumn{5}{|l|}{ Marital status $\S$} \\
\hline Married & $15,934(16.1)$ & $5,977(7.3)$ & $6,026(25.8)$ & 27,937 (13.7) \\
\hline Unmarried & 82,847 (83.9) & $76,313(92.7)$ & $17,364(74.2)$ & $176,524(86.3)$ \\
\hline Total & $98,781(100.0)$ & $82,290(100.0)$ & $23,390(100.0)$ & $204,461(100.0)$ \\
\hline
\end{tabular}

* Percentages for the individual component categories might not add to 100 because of rounding.

† Data from 34 reporting areas; excludes 18 areas (Arizona, California, Connecticut, Florida, Illinois, Kentucky, Maryland, Massachusetts, Nevada, New Hampshire, New Mexico, New York State, New York City, Pennsylvania, Texas, Washington, Wisconsin, and Wyoming) that did not report, did not report race by age, or did not meet reporting standards.

$\S$ Data from 30 reporting areas; excludes 22 areas (Arizona, California, Connecticut, District of Columbia, Florida, Illinois, Kentucky, Maryland, Massachusetts, Nevada, New Hampshire, New Mexico, New York State, New York City, North Carolina, Ohio, Pennsylvania, Rhode Island, Texas, Washington, Wisconsin, and Wyoming) that did not report, did not report race by marital status, or did not meet reporting standards. 
TABLE 19. Reported abortions, by known race/ethnicity, age group, and marital status of women who obtained an abortion — selected reporting areas, United States, 2015

\begin{tabular}{|c|c|c|c|c|c|}
\hline \multirow[b]{3}{*}{ Characteristic } & \multicolumn{3}{|c|}{ Non-Hispanic } & \multirow[b]{2}{*}{ Hispanic } & \multirow[b]{2}{*}{ Total } \\
\hline & White & Black & Other & & \\
\hline & No. $(\%)^{*}$ & No. (\%) & No. (\%) & No. (\%) & No. (\%) \\
\hline \multicolumn{6}{|c|}{ Age group $(y r s)^{\dagger}$} \\
\hline$<15$ & $238(0.2)$ & $369(0.3)$ & $50(0.2)$ & $218(0.3)$ & $875(0.3)$ \\
\hline $15-19$ & $11,683(9.5)$ & $11,501(9.5)$ & $2,215(7.6)$ & $6,541(10.5)$ & $31,940(9.5)$ \\
\hline 15 & $551(0.4)$ & $709(0.6)$ & $103(0.4)$ & $339(0.5)$ & $1,702(0.5)$ \\
\hline 16 & $935(0.8)$ & $1,168(1.0)$ & $193(0.7)$ & $660(1.1)$ & $2,956(0.9)$ \\
\hline 17 & $1,716(1.4)$ & $1,830(1.5)$ & $308(1.1)$ & $1,003(1.6)$ & $4,857(1.4)$ \\
\hline 18 & $3,485(2.8)$ & $3,253(2.7)$ & $654(2.2)$ & $1,878(3.0)$ & $9,270(2.8)$ \\
\hline 19 & $4,996(4.1)$ & $4,541(3.8)$ & $957(3.3)$ & $2,661(4.3)$ & 13,155 (3.9) \\
\hline $20-24$ & $37,275(30.4)$ & $38,876(32.2)$ & $7,724(26.5)$ & 19,939 (31.9) & $103,814(31.0)$ \\
\hline $25-29$ & $33,410(27.2)$ & $34,770(28.8)$ & $7,774(26.7)$ & $16,703(26.7)$ & $92,657(27.7)$ \\
\hline $30-34$ & 21,943 (17.9) & 20,915 (17.3) & $5,829(20.0)$ & $10,840(17.3)$ & $59,527(17.8)$ \\
\hline $35-39$ & $13,104(10.7)$ & $11,022(9.1)$ & $3,822(13.1)$ & $6,122(9.8)$ & $34,070(10.2)$ \\
\hline$\geq 40$ & $4,955(4.0)$ & $3,363(2.8)$ & $1,684(5.8)$ & $2,122(3.4)$ & $12,124(3.6)$ \\
\hline Total & $122,608(100.0)$ & $120,816(100.0)$ & $29,098(100.0)$ & $62,485(100.0)$ & $335,007(100.0)$ \\
\hline \multicolumn{6}{|l|}{ Marital status $\S$} \\
\hline Married & $17,558(17.0)$ & $8,840(8.2)$ & $8,110(31.0)$ & 8,708 (15.6) & $43,216(14.7)$ \\
\hline Unmarried & $85,900(83.0)$ & $98,886(91.8)$ & $18,065(69.0)$ & $47,021(84.4)$ & $249,872(85.3)$ \\
\hline Total & $103,458(100.0)$ & $107,726(100.0)$ & $26,175(100.0)$ & $55,729(100.0)$ & $293,088(100.0)$ \\
\hline
\end{tabular}


TABLE 20. Reported abortions, by known weeks of gestation, age group, and race/ethnicity of women who obtained an abortion — selected reporting areas, United States, 2015

\begin{tabular}{|c|c|c|c|c|c|c|}
\hline \multirow[b]{3}{*}{ Characteristic } & \multicolumn{6}{|c|}{ Weeks of gestation } \\
\hline & $\leq 8$ & $9-13$ & $14-15$ & $16-17$ & $18-20$ & $\geq 21$ \\
\hline & No. (\%) & No. (\%) & No. (\%) & No. (\%) & No. (\%) & No. (\%) \\
\hline \multicolumn{7}{|c|}{ Age group (yrs)*,† } \\
\hline$<15$ & $441(39.0)$ & $416(36.8)$ & $81(7.2)$ & $72(6.4)$ & $55(4.9)$ & $66(5.8)$ \\
\hline $15-19$ & $23,096(56.7)$ & $12,644(31.0)$ & $1,855(4.6)$ & $1,155(2.8)$ & $1,133(2.8)$ & $841(2.1)$ \\
\hline $20-24$ & $83,216(63.5)$ & $35,597(27.2)$ & $4,950(3.8)$ & $2,956(2.3)$ & $2,625(2.0)$ & $1,655(1.3)$ \\
\hline $25-29$ & $77,945(67.0)$ & $28,969(24.9)$ & $3,889(3.3)$ & $2,223(1.9)$ & $2,010(1.7)$ & $1,318(1.1)$ \\
\hline $30-34$ & $51,351(68.4)$ & $17,720(23.6)$ & $2,322(3.1)$ & $1,363(1.8)$ & $1,368(1.8)$ & $951(1.3)$ \\
\hline $35-39$ & $29,596(68.9)$ & $9,863(23.0)$ & $1,374(3.2)$ & 817 (1.9) & 792 (1.8) & $502(1.2)$ \\
\hline$\geq 40$ & $10,790(70.5)$ & $3,285(21.5)$ & $460(3.0)$ & $282(1.8)$ & 290 (1.9) & $200(1.3)$ \\
\hline Total & $276,435(65.4)$ & $108,494(25.7)$ & $14,931(3.5)$ & $8,868(2.1)$ & $8,273(2.0)$ & $5,533(1.3)$ \\
\hline \multicolumn{7}{|c|}{ Race/Ethnicity*,§ } \\
\hline \multicolumn{7}{|c|}{ Non-Hispanic } \\
\hline White & $82,889(67.7)$ & $29,683(24.2)$ & $3,898(3.2)$ & $2,213(1.8)$ & $2,249(1.8)$ & $1,510(1.2)$ \\
\hline Black & $70,937(59.1)$ & $36,360(30.3)$ & $4,931(4.1)$ & $3,034(2.5)$ & $2,909(2.4)$ & $1,790(1.5)$ \\
\hline Other & $20,448(70.3)$ & $6,252(21.5)$ & $900(3.1)$ & $584(2.0)$ & $580(2.0)$ & $343(1.2)$ \\
\hline Hispanic & $42,110(67.5)$ & $14,970(24.0)$ & $2,161(3.5)$ & $1,248(2.0)$ & $1,186(1.9)$ & $703(1.1)$ \\
\hline Total & $216,384(64.8)$ & $87,265(26.1)$ & $11,890(3.6)$ & $7,079(2.1)$ & $6,924(2.1)$ & $4,346(1.3)$ \\
\hline
\end{tabular}

* Row percentages might not add to 100 because of rounding.

† Data from 39 reporting areas; excludes 13 reporting areas (California, Connecticut, District of Columbia, Florida, Illinois, Kentucky, Maryland, Massachusetts, New Hampshire, New York State, Pennsylvania, Wisconsin, and Wyoming) that did not report, did not report weeks of gestation by age, or did not meet reporting standards.

$\S$ Data from 28 reporting areas; excludes 24 reporting areas (California, Connecticut, District of Columbia, Florida, Illinois, lowa, Kentucky, Louisiana, Maine, Maryland, Massachusetts, Mississippi, Nebraska, New Hampshire, New Mexico, New York State, North Carolina, North Dakota, Oklahoma, Pennsylvania, Rhode Island, Washington, Wisconsin, and Wyoming) that did not report, did not report weeks of gestation by race/ethnicity, or did not meet reporting standards. 
TABLE 21. Reported abortions obtained at $\leq 13$ weeks' gestation, by known weeks of gestation, age group, and race/ethnicity of women who obtained an abortion — selected reporting areas, United States, 2015

\begin{tabular}{|c|c|c|c|c|c|c|c|c|}
\hline \multirow[b]{3}{*}{ Characteristic } & \multicolumn{8}{|c|}{ Weeks of gestation } \\
\hline & $\leq 6$ & 7 & 8 & 9 & 10 & 11 & 12 & 13 \\
\hline & No. (\%) & No. (\%) & No. (\%) & No. (\%) & No. (\%) & No. (\%) & No. (\%) & No. (\%) \\
\hline \multicolumn{9}{|c|}{ Age group (yrs)*,† } \\
\hline$<15$ & $189(22.1)$ & $133(15.5)$ & $119(13.9)$ & $118(13.8)$ & $85(9.9)$ & 87 (10.2) & $66(7.7)$ & $60(7.0)$ \\
\hline $15-19$ & 11,067 (31.0) & $6,489(18.2)$ & $5,540(15.5)$ & $4,119(11.5)$ & 2,787 (7.8) & $2,422(6.8)$ & $1,801(5.0)$ & $1,515(4.2)$ \\
\hline $20-24$ & $42,051(35.4)$ & $23,164(19.5)$ & $18,001(15.2)$ & $12,059(10.1)$ & $8,126(6.8)$ & $6,691(5.6)$ & $4,868(4.1)$ & $3,853(3.2)$ \\
\hline $25-29$ & $41,359(38.7)$ & 21,159 (19.8) & $15,427(14.4)$ & $10,300(9.6)$ & $6,506(6.1)$ & $5,274(4.9)$ & $3,814(3.6)$ & $3,075(2.9)$ \\
\hline $30-34$ & $27,808(40.3)$ & 13,751 (19.9) & $9,792(14.2)$ & $6,357(9.2)$ & $3,962(5.7)$ & $3,196(4.6)$ & $2,343(3.4)$ & $1,862(2.7)$ \\
\hline $35-39$ & $16,135(40.9)$ & $7,883(20.0)$ & $5,578(14.1)$ & $3,644(9.2)$ & $2,201(5.6)$ & $1,622(4.1)$ & $1,341(3.4)$ & $1,055(2.7)$ \\
\hline$\geq 40$ & $6,263(44.5)$ & $2,710(19.3)$ & $1,817(12.9)$ & $1,180(8.4)$ & $684(4.9)$ & $599(4.3)$ & $437(3.1)$ & $385(2.7)$ \\
\hline Total & $144,872(37.6)$ & $75,289(19.6)$ & $56,274(14.6)$ & $37,777(9.8)$ & $24,351(6.3)$ & $19,891(5.2)$ & $14,670(3.8)$ & $11,805(3.1)$ \\
\hline \multirow{2}{*}{\multicolumn{9}{|c|}{ Race/Ethnicity*,§ }} \\
\hline & \multicolumn{8}{|c|}{ Non-Hispanic } \\
\hline White & $44,697(39.7)$ & $22,011(19.6)$ & $16,181(14.4)$ & $10,749(9.5)$ & $6,541(5.8)$ & $5,357(4.8)$ & $3,816(3.4)$ & $3,220(2.9)$ \\
\hline Black & 33,129 (30.9) & $21,052(19.6)$ & $16,756(15.6)$ & $12,047(11.2)$ & $8,329(7.8)$ & $6,940(6.5)$ & $5,210(4.9)$ & $3,834(3.6)$ \\
\hline Other & $11,554(43.3)$ & 5,201 (19.5) & 3,693 (13.8) & $2,324(8.7)$ & $1,370(5.1)$ & $1,040(3.9)$ & $791(3.0)$ & $727(2.7)$ \\
\hline Hispanic & $23,271(40.8)$ & $10,988(19.3)$ & $7,851(13.8)$ & $5,357(9.4)$ & $3,495(6.1)$ & $2,666(4.7)$ & $1,910(3.3)$ & $1,542(2.7)$ \\
\hline Total & $112,651(37.1)$ & $59,252(19.5)$ & $44,481(14.6)$ & $30,477(10.0)$ & $19,735(6.5)$ & $16,003(5.3)$ & $11,727(3.9)$ & $9,323(3.1)$ \\
\hline
\end{tabular}


TABLE 22. Reported abortions, by known weeks of gestation and method type - selected reporting areas,* United States, 2015

\begin{tabular}{|c|c|c|c|c|c|c|c|}
\hline \multirow[b]{3}{*}{ Method type } & \multicolumn{6}{|c|}{ Weeks of gestation } & \multirow[b]{2}{*}{ Total } \\
\hline & $\leq 8$ & $9-13$ & $14-15$ & $16-17$ & $18-20$ & $\geq 21$ & \\
\hline & No. $(\%)^{\dagger}$ & No. (\%) & No. $(\%)$ & No. (\%) & No. (\%) & No. (\%) & No. (\%) \\
\hline $\begin{array}{l}\text { Surgical }{ }^{\S} \\
\leq 13 \text { weeks' gestation } \\
>13 \text { weeks' gestation }\end{array}$ & $\begin{array}{r}166,476(64.2) \\
\text { NA }\end{array}$ & $\begin{array}{r}95,604 \text { (94.5) } \\
\text { NA }\end{array}$ & $\begin{array}{r}\text { NA } \\
13,768(99.2)\end{array}$ & $\begin{array}{r}\text { NA } \\
8,378(98.9)\end{array}$ & $\begin{array}{r}\text { NA } \\
7,735(97.7)\end{array}$ & $\begin{array}{r}N A \\
4,573(94.5)\end{array}$ & $\begin{array}{r}262,080(66.2) \\
34,454(8.7)\end{array}$ \\
\hline $\begin{array}{l}\text { Medical" } \\
\leq 8 \text { weeks' gestation } \\
>8 \text { weeks' gestation }\end{array}$ & $\begin{array}{r}92,971 \text { (35.8) } \\
\text { NA }\end{array}$ & $\begin{array}{r}\mathrm{NA} \\
5,537(5.5)\end{array}$ & $\begin{array}{r}N A \\
91(0.7)\end{array}$ & $\begin{array}{r}N A \\
82(1.0)\end{array}$ & $\begin{array}{r}\text { NA } \\
153(1.9)\end{array}$ & $\begin{array}{r}\text { NA } \\
219(4.5)\end{array}$ & $\begin{array}{r}92,971(23.5) \\
6,082(1.5)\end{array}$ \\
\hline Intrauterine instillation & - ${ }^{* *}$ & $-^{\dagger+}$ & $13(0.1)$ & $-{ }^{\dagger+}$ & $16(0.2)$ & $33(0.7)$ & $74(0.0)$ \\
\hline Hysterectomy/Hysterotomy & $9(0.0)$ & $-{ }^{\dagger+}$ & $7(0.1)$ & $-^{\dagger+}$ & $16(0.2)$ & $12(0.2)$ & $55(0.0)$ \\
\hline Total & $259,456(100.0)$ & $101,152(100.0)$ & $13,879(100.0)$ & $8,472(100.0)$ & $7,920(100.0)$ & $4,837(100.0)$ & $395,716(100.0)$ \\
\hline
\end{tabular}

Abbreviation: $\mathrm{NA}=$ not applicable.

* Data from 35 reporting areas; excludes 17 areas (California, Connecticut, District of Columbia, Florida, Hawaii, Illinois, Kentucky, Louisiana, Maryland, Massachusetts, New Hampshire, New Mexico, New York State, Pennsylvania, Tennessee, Wisconsin, and Wyoming) that did not report, did not report method type by weeks of gestation, did not meet reporting standards, or did not have medical abortion as a specific category on their reporting form.

† For each gestational age category, percentages of all method types might not add to 100 because of rounding.

$\S$ Includes aspiration curettage, suction curettage, manual vacuum aspiration, menstrual extraction, sharp curettage, and dilation and evacuation procedures.

I The administration of medication or medications to induce an abortion; at $\leq 8$ weeks' gestation, typically involves the use of mifepristone and misoprostol; at $>8$ weeks' gestation, typically involves the use of vaginal prostaglandins.

** Intrauterine instillations reported at $\leq 12$ weeks' gestation have not been included with known values.

${ }^{+\dagger}$ Cells with a value in the range of 1-4 or cells that would allow for calculation of these small values have been suppressed. 
TABLE 23. Number of deaths and case-fatality rates* for abortion-related deaths reported to CDC, by type of abortion - United States, 1973-2014

\begin{tabular}{|c|c|c|c|c|c|}
\hline \multirow[b]{3}{*}{ Year } & \multicolumn{4}{|c|}{ Type of abortion } & \multirow{3}{*}{$\begin{array}{l}\text { CFR per } 100,000 \\
\text { legal abortions }\end{array}$} \\
\hline & \multicolumn{2}{|c|}{ Induced } & \multirow[b]{2}{*}{ Unknown** } & \multirow[b]{2}{*}{ Total } & \\
\hline & Legal $\$$ & Illegalף & & & \\
\hline 1973-1977 & & & & & 2.09 \\
\hline 1973 & 25 & 19 & 3 & 47 & \\
\hline 1974 & 26 & 6 & 1 & 33 & \\
\hline 1975 & 29 & 4 & 1 & 34 & \\
\hline 1976 & 11 & 2 & 1 & 14 & \\
\hline 1977 & 17 & 4 & 0 & 21 & \\
\hline 1978-1982 & & & & & 0.78 \\
\hline 1978 & 9 & 7 & 0 & 16 & \\
\hline 1979 & 22 & 0 & 0 & 22 & \\
\hline 1980 & 9 & 1 & 2 & 12 & \\
\hline 1981 & 8 & 1 & 0 & 9 & \\
\hline 1982 & 11 & 1 & 0 & 12 & \\
\hline 1983-1987 & & & & & 0.66 \\
\hline 1983 & 11 & 1 & 0 & 12 & \\
\hline 1984 & 12 & 0 & 0 & 12 & \\
\hline 1985 & 11 & 1 & 1 & 13 & \\
\hline 1986 & 11 & 0 & 2 & 13 & \\
\hline 1987 & 7 & 2 & 0 & 9 & \\
\hline 1988-1992 & & & & & 0.74 \\
\hline 1988 & 16 & 0 & 0 & 16 & \\
\hline 1989 & 12 & 1 & 0 & 13 & \\
\hline 1990 & 9 & 0 & 0 & 9 & \\
\hline 1991 & 11 & 1 & 0 & 12 & \\
\hline 1992 & 10 & 0 & 0 & 10 & \\
\hline 1993-1997 & & & & & 0.52 \\
\hline 1993 & 6 & 1 & 2 & 9 & \\
\hline 1994 & 10 & 2 & 0 & 12 & \\
\hline 1995 & 4 & 0 & 0 & 4 & \\
\hline 1996 & 9 & 0 & 0 & 9 & \\
\hline 1997 & 7 & 0 & 0 & 7 & \\
\hline 1998-2002 & & & & & 0.63 \\
\hline 1998 & 9 & 0 & 0 & 9 & \\
\hline 1999 & 4 & 0 & 0 & 4 & \\
\hline 2000 & 11 & 0 & 0 & 11 & \\
\hline 2001 & 7 & 1 & 0 & 8 & \\
\hline 2002 & 10 & 0 & 0 & 10 & \\
\hline $2003-2007$ & & & & & 0.60 \\
\hline 2003 & 10 & 0 & 0 & 10 & \\
\hline 2004 & 7 & 1 & 0 & 8 & \\
\hline 2005 & 7 & 0 & 0 & 7 & \\
\hline 2006 & 7 & 0 & 0 & 7 & \\
\hline 2007 & 6 & 0 & 0 & 6 & \\
\hline 2008-2014 & & & & & 0.62 \\
\hline 2008 & 12 & 0 & 0 & 12 & \\
\hline 2009 & 8 & 0 & 0 & 8 & \\
\hline 2010 & 10 & 0 & 0 & 10 & \\
\hline 2011 & 2 & 0 & 0 & 2 & \\
\hline 2012 & 4 & 0 & 0 & 4 & \\
\hline 2013 & 4 & 0 & 0 & 4 & \\
\hline 2014 & 6 & 0 & 0 & 6 & \\
\hline Total & 437 & 56 & 13 & 506 & 0.79 \\
\hline
\end{tabular}

Abbreviation: $\mathrm{CFR}=$ case-fatality rate.

* Number of legal induced abortion-related deaths per 100,000 reported legal induced abortions. Because a substantial number of legal induced abortions occurred outside reporting areas that provided data to CDC, national case-fatality rates (i.e., number of legal induced abortion-related deaths per 100,000 reported legal induced abortions in the United States) were calculated with denominator data from a more complete source (16). Case-fatality rates were computed for consecutive 5-year periods during 1973-2007 and then for a consecutive 7-year period during 2008-2014 because rates based on <20 cases are highly variable (43) .

† Certain numbers might differ from those in reports published previously because additional information has been supplied to CDC subsequent to publication.

$\S$ An abortion is defined as legal if it was performed by a licensed clinician within the limits of state law.

" An abortion is defined as illegal if it was performed by any person other than a licensed clinician.

** Unknown whether abortion was induced or spontaneous. 
The Morbidity and Mortality Weekly Report (MMWR) Series is prepared by the Centers for Disease Control and Prevention (CDC) and is available free of charge in electronic format. To receive an electronic copy each week, visit MMWR at https://www.cdc.gov/mmwr/index.html.

Readers who have difficulty accessing this PDF file may access the HTML file at https://www.cdc.gov/mmwr/volumes/67/ss/ss6713a1.htm?s_ cid=ss6713a1_w. Address all inquiries about the $M M W R$ Series, including material to be considered for publication, to Executive Editor, $M M W R$ Series, Mailstop E-90, CDC, 1600 Clifton Rd., N.E., Atlanta, GA 30329-4027 or to mmwrq@cdc.gov.

All material in the MMWR Series is in the public domain and may be used and reprinted without permission; citation as to source, however, is appreciated. MMWR and Morbidity and Mortality Weekly Report are service marks of the U.S. Department of Health and Human Services.

Use of trade names and commercial sources is for identification only and does not imply endorsement by the U.S. Department of Health and Human Services.

References to non-CDC sites on the Internet are provided as a service to $M M W R$ readers and do not constitute or imply endorsement of these organizations or their programs by CDC or the U.S. Department of Health and Human Services. CDC is not responsible for the content of these sites. URL addresses listed in $M M W R$ were current as of the date of publication.

ISSN: 0149-2195 (Print) 